
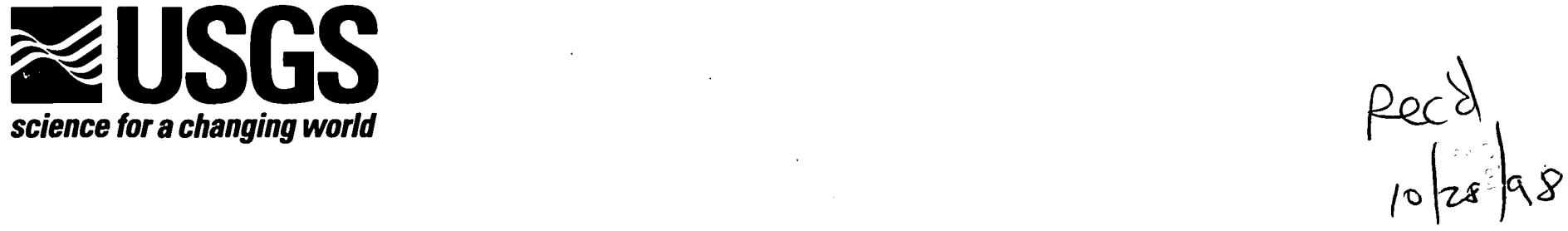

In cooperation with the

U.S. Army Garrison, Aberdeen Proving Ground

Environmental Conservation and Restoration Division

Aberdeen Proving Ground, Maryland

\title{
Assessment of Soil, Surface-Water, and Ground-Water Contamination at Selected Sites at J-Field, Aberdeen Proving Ground, Maryland
}

Water-Resources Investigations Report 98-4037 


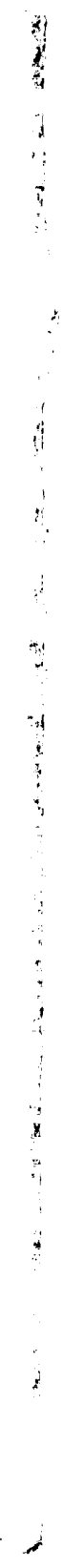

3
3
4
4
4
4
4
4
4
4
4 


\section{Assessment of Soil, Surface-Water, and Ground-Water Contamination at Selected Sites at J-Field, Aberdeen Proving Ground, Maryland}

by Daniel J. Phelan, Lisa D. Olsen, Martha L. Cashel, Judith L. Tegeler, and Elizabeth H. Marchand

Water-Resources Investigations Report 98-4037

In cooperation with the

U.S. Army Garrison, Aberdeen Proving Ground

Environmental Conservation and Restoration Division

Aberdeen Proving Ground, Maryland

The contents of this report have been approved for public release and unlimited distribution by the U.S. Army -distribution number 2566-A-3. 


\section{U.S. Department of the Interior}

Bruce Babbitt, Secretary

\section{U.S. Geological Survey}

Thomas J. Casadevall, Acting Director

The use of trade, product, or firm names in this report is for descriptive purposes only and does not imply endorsement by the U.S. Geological Survey.

United States Government Printing Office: 1998

For additional information contact:

District Chief

U.S. Geological Survey, WRD

8987 Yellow Brick Road

Baltimore, MD 21237

Copies of this report can be purchased from:

U.S. Geological Survey

Branch of Information Services

Box 25286

Denver, CÓ 80225-0286 

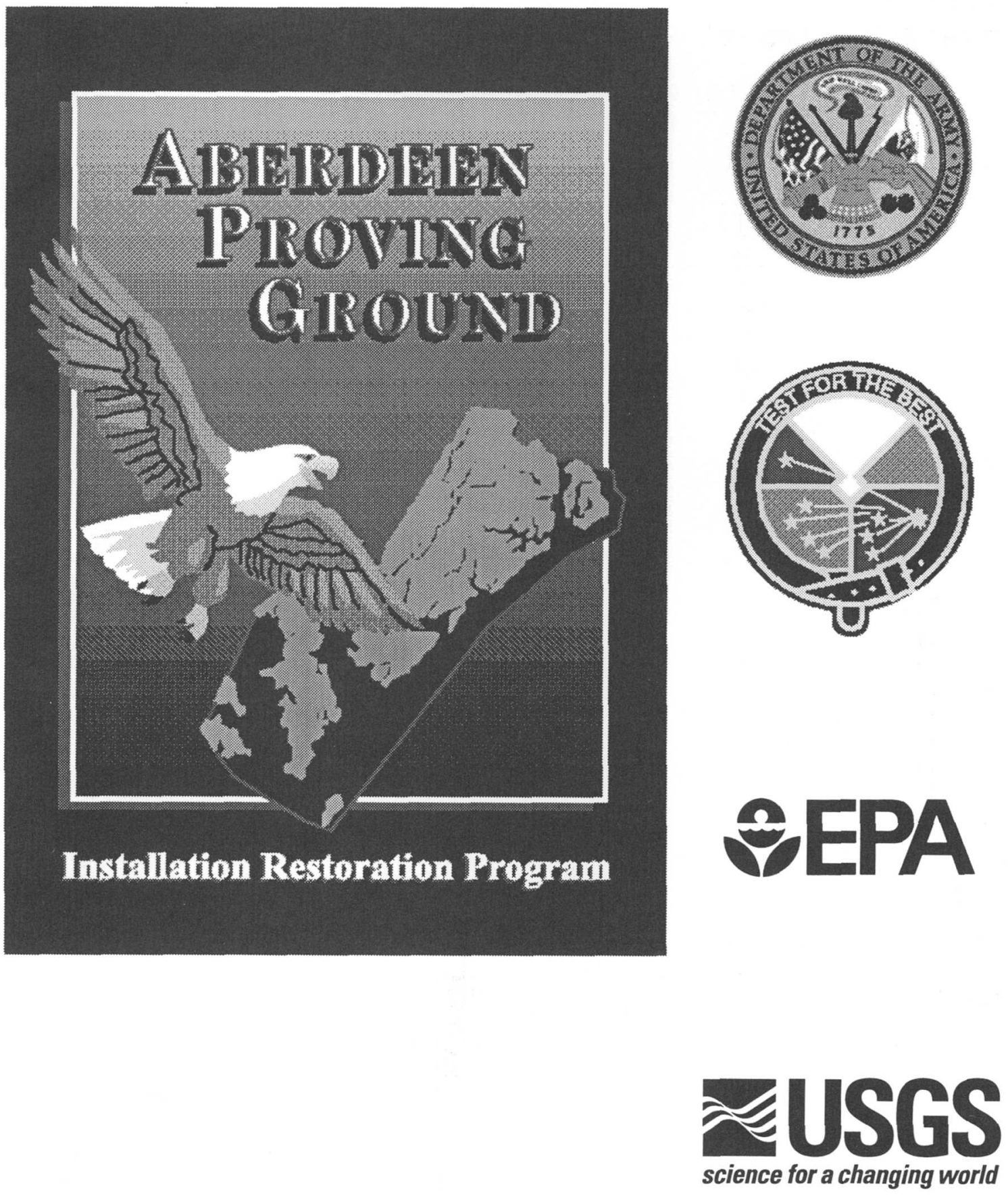

\section{8}

Aberdeen Proving Ground, Edgewood Area 


\section{CONTENTS}

Abstract

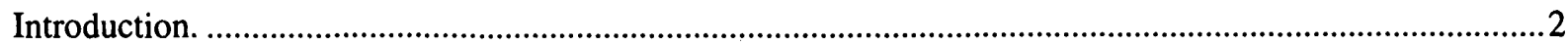

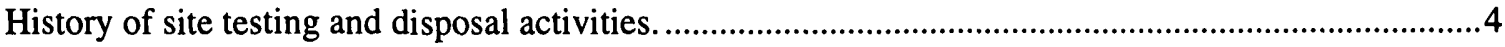

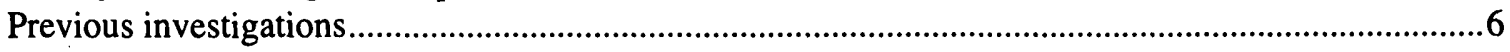

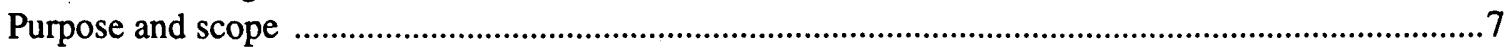

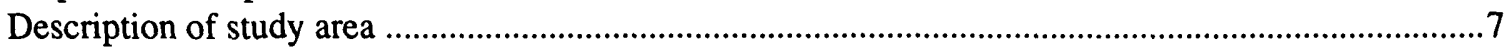

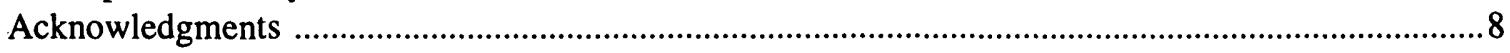

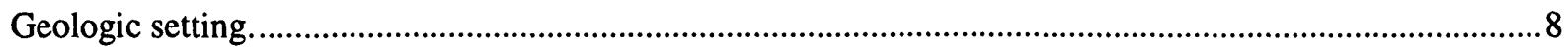

Hydrologic setting.

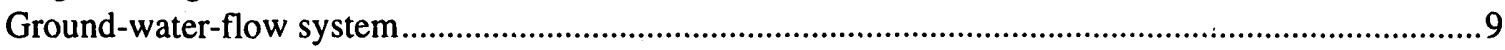

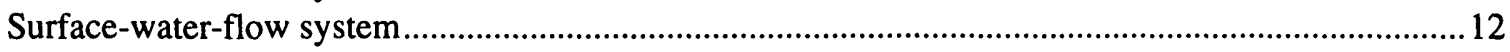

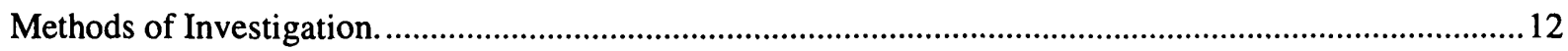

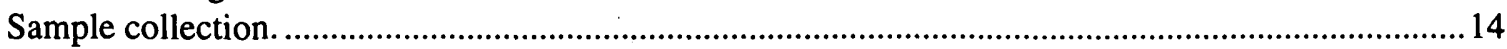

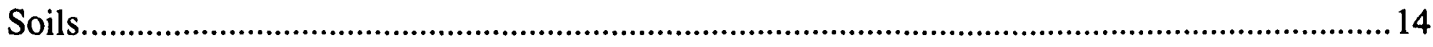

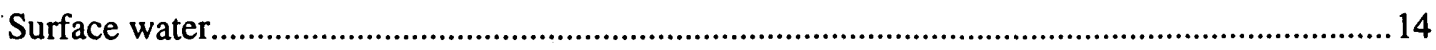

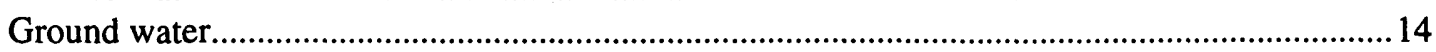

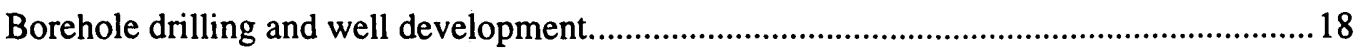

Well-numbering system. .................................................................................................. 18

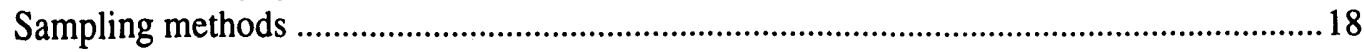

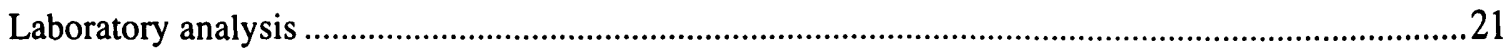

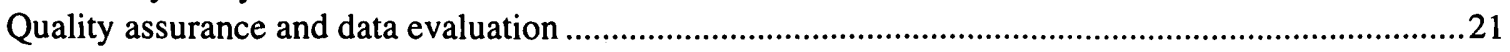

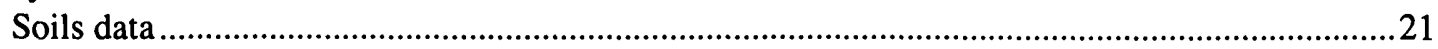

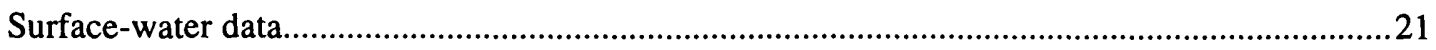

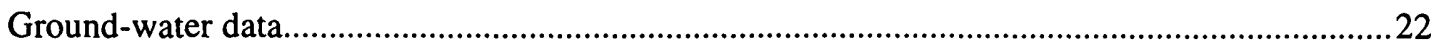

Assessment of soil, surface-water, and ground-water contamination at selected J-Field sites .....................22

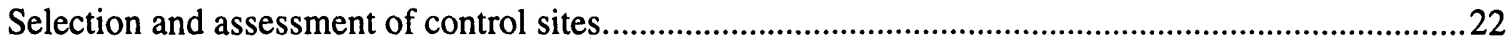

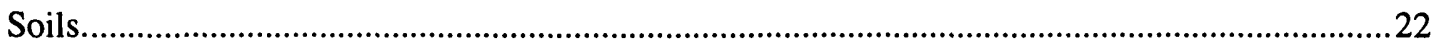

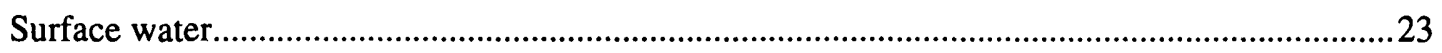

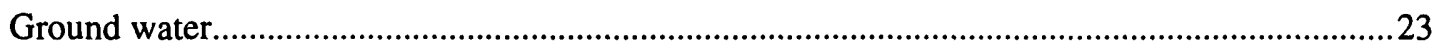

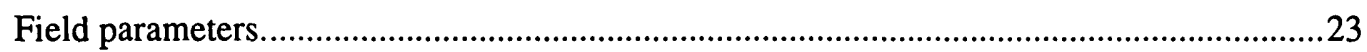

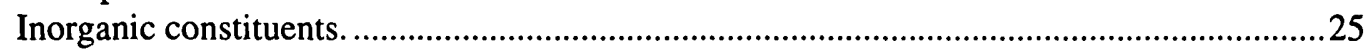

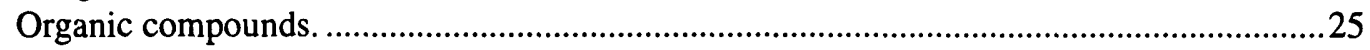

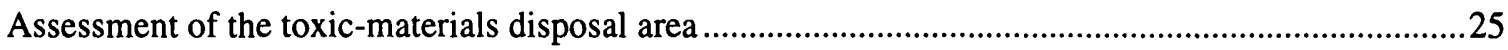

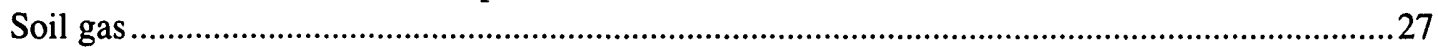

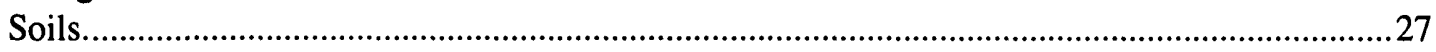

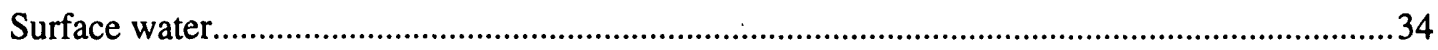

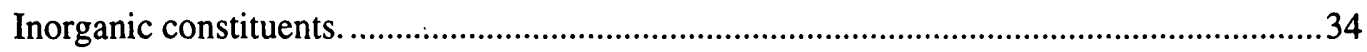

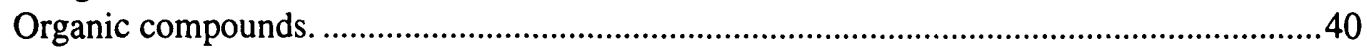

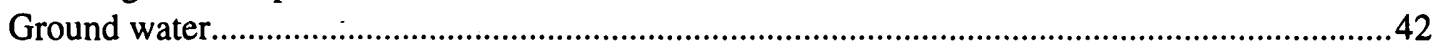

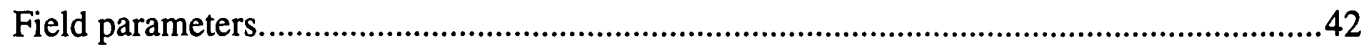

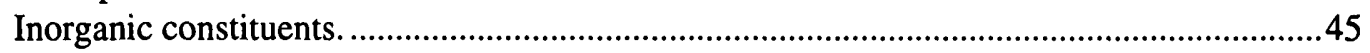

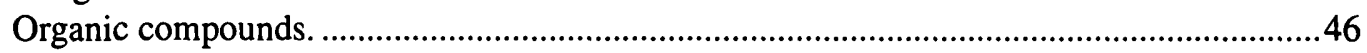

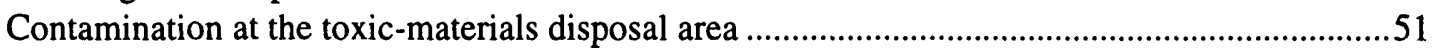




\section{CONTENTS--Continued}

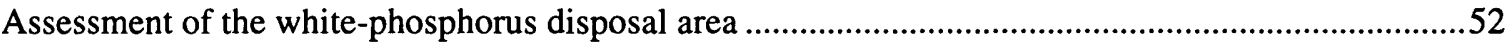

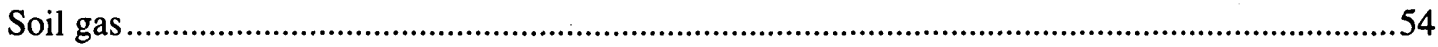

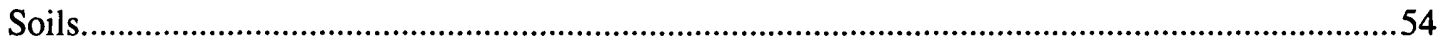

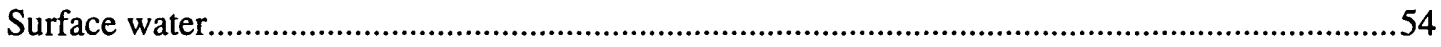

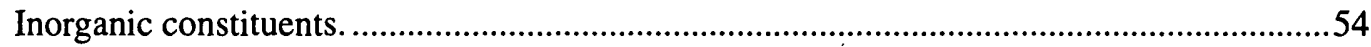

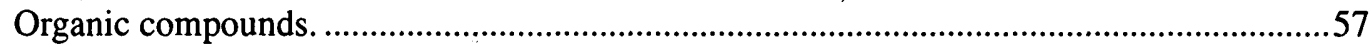

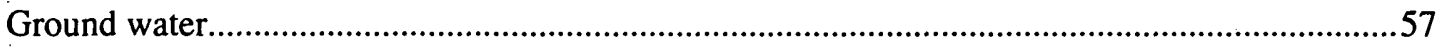

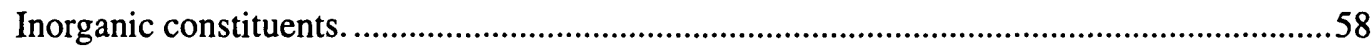

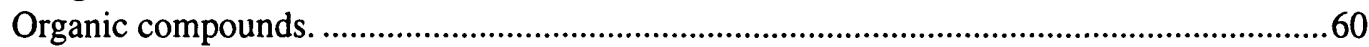

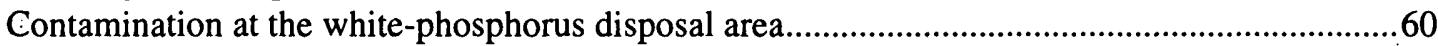

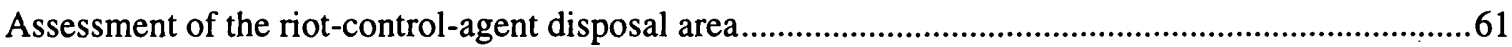

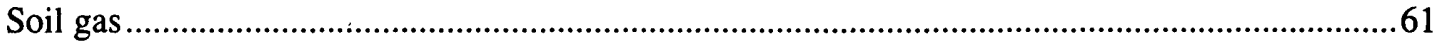

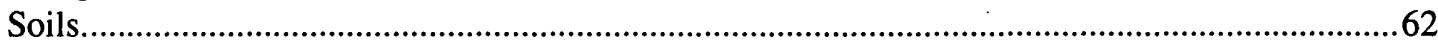

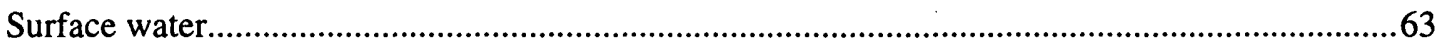

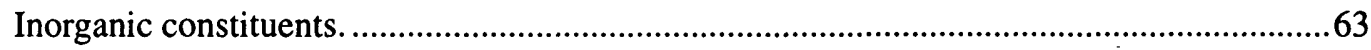

Organic compounds.

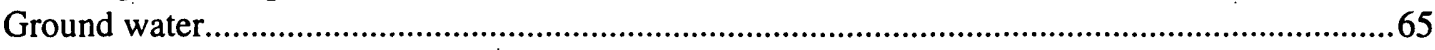

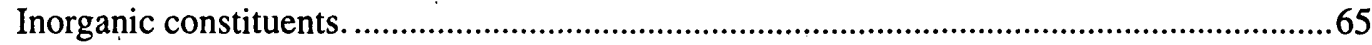

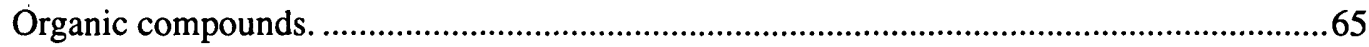

Contamination at the riot-control-agent disposal area ..................................................................66

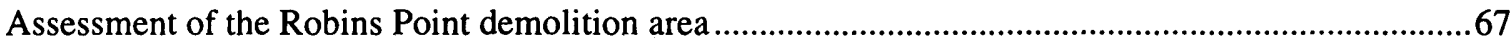

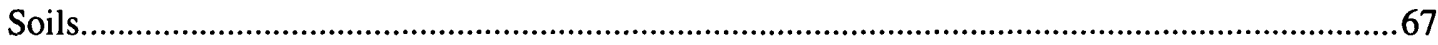

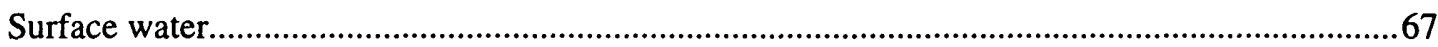

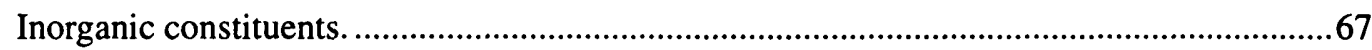

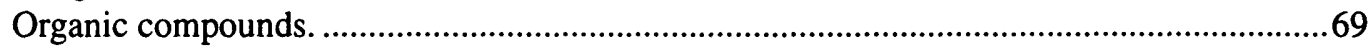

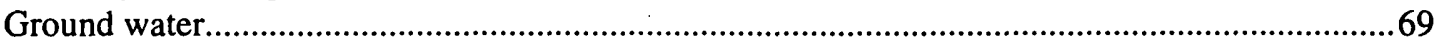

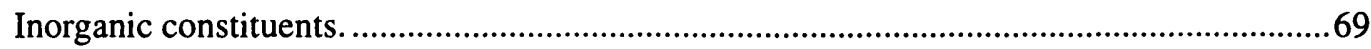

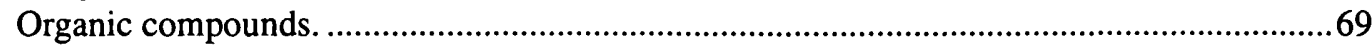

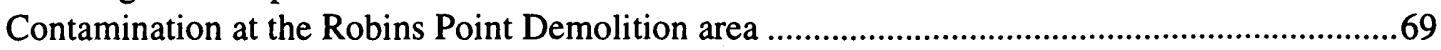

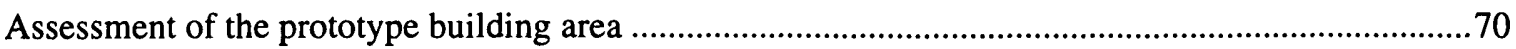

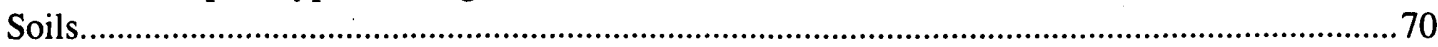

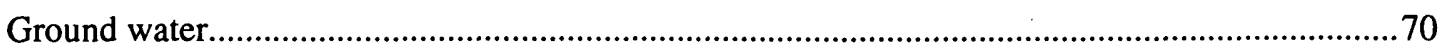

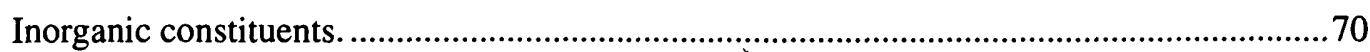

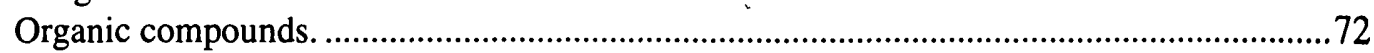

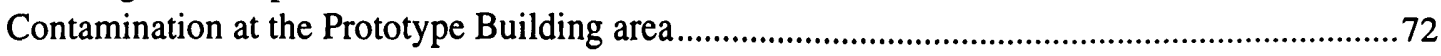

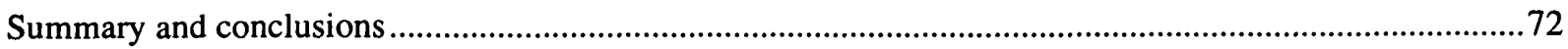

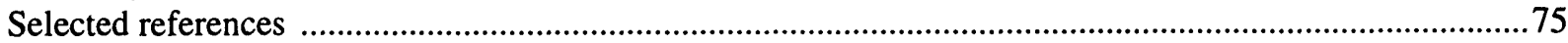




\section{FIGURES}

1-3. Maps showing location of:

1. J-Field study area, Aberdeen Proving Ground, Maryland

2. Solid-waste management units, the prototype building,

South Beach, and land-cover types at J-Field,

Aberdeen Proving Ground, Maryland

3. Estimated extent of paleochannel deposits at J-Field,

Aberdeen Proving Ground, Maryland

4. Schematic diagram showing hydrogeologic units and general

ground-water-flow direction in the J-Field area,

Aberdeen Proving Ground, Maryland.

5- 6. Maps showing hydraulic head and direction of ground-water flow in the:

5. Surficial aquifer, November 1989 ,

J-Field, Aberdeen Proving Ground, Maryland............................................................... 11

6. Confined aquifer, November 1989 ,

J-Field, Aberdeen Proving Ground, Maryland................................................................

7- 9. Maps showing locations of:

7. Soil-quality-sampling sites, April 1991,

J-Field, Aberdeen Proving Ground, Maryland

8. Surface-water-sampling sites, April and September 1993,

J-Field, Aberdeen Proving Ground, Maryland.

9. Wells at J-Field, Aberdeen Proving Ground, Maryland

10. Map showing results of Phase I soil-gas analyses compared to organic compounds detected in the surficial aquifer during Phase I and II ground-water sampling, and directions of ground-water flow in the surficial aquifer at the toxic-materials disposal area,

J-Field, Aberdeen Proving Ground, Maryland.

11. Map showing organic compounds and trace metals

detected in soils at the toxic-materials disposal area,

J-Field, Aberdeen Proving Ground, Maryland

12-13. Maps showing concentrations of:

12. Trace metals detected in surface water at the toxic-materials disposal area, spring and fall 1993,

J-Field, Aberdeen Proving Ground, Maryland.

13. Volatile organic compounds detected in surface water at the toxic-materials disposal area, spring and fall 1993, J-Field, Aberdeen Proving Ground, Maryland 


\section{FIGURES--Continued}

14. Graph showing concentrations of total volatile organic compounds, and the proportions of individual compounds detected in surface water during April 1993 at J-Field, Aberdeen Proving Ground, Maryland

15. Map showing distribution of $\mathrm{pH}$ values greater than 8.0 in wells at J-Field, Aberdeen Proving Ground, Maryland....

16. Graphs showing concentrations of total volatile organic compounds, and the proportions of individual compounds detected in ground water sampled at the toxic-materials disposal area, J-Field, Aberdeen Proving Ground, Maryland, during:

a. Phase I.

b. Phase II

17-18. Maps showing results of Phase I soil-gas analyses compared to organic compounds detected in the surficial aquifer during Phase I and II ground-water sampling:

17. Directions of ground-water flow in the surficial aquifer, and soil-quality data at the white-phosphorus disposal area, J-Field, Aberdeen Proving Ground, Maryland.

18. Spring 1993 surface-water sampling, and the directions of ground-water flow in the surficial aquifer at the riot-control-agent disposal area, J-Field, Aberdeen Proving Ground, Maryland

19. Concentrations of trace metals in soils and surface-water samples at the riot-control-agent disposal area, J-Field, Aberdeen Proving Ground, Maryland.

\section{TABLES}

1. Well-construction data for observation wells installed at J-Field,

Aberdeen Proving Ground, Maryland

2. Ground-water control-wells at J-Field, Aberdeen Proving Ground, Maryland

3-4. Summary statistics for:

3. Field parameters in Phase I ground-water samples from control wells, May -June 1990, J-Field, Aberdeen Proving Ground, Maryland

4. Dissolved trace metals in Phase I and II ground-water samples

from control wells, J-Field, Aberdeen Proving Ground, Maryland

5. Inorganic constituents detected in soils at J-Field, Aberdeen Proving Ground, Maryland.

6. Summary statistics for metal concentrations in soils at the toxic-materials disposal area, and enrichment factors compared to average crustal abundances, J-Field, Aberdeen Proving Ground, Maryland

7. Organic compounds detected in soils at J-Field,

Aberdeen Proving Ground, Maryland 


\section{TABLES--Continued}

8. Surface-water quality data from J-Field, Aberdeen Proving

Ground, Maryland--inorganic constituents, spring and fall 1993

9. Surface-water quality data from J-Field, Aberdeen Proving

Ground, Maryland--organic compounds, spring and fall 1993.

10. Dissolved trace metals detected in ground water at the toxic-materials

disposal area during Phase I sampling, May - June 1990,

J-Field, Aberdeen Proving Ground, Maryland

11-12. Organic compounds detected in ground water at the toxic-materials disposal area:

11. Phase I sampling, May-June 1990, J-Field, Aberdeen Proving Ground, Maryland

12. Phase II sampling, November 1992 -

January 1993, J-Field, Aberdeen Proving Ground, Maryland

13. Summary statistics for metal concentrations in soils at the white-phosphorus disposal area, and enrichment factors compared to average crustal abundances, J-Field, Aberdeen Proving Ground, Maryland

14. Dissolved trace metals detected in ground water at the white-phosphorus disposal area during Phase I sampling, May -June 1990, J-Field,

Aberdeen Proving Ground, Maryland

15. Organic compounds detected in ground water during Phase I and II sampling at the white-phosphorus disposal area,

J-Field, Aberdeen Proving Ground, Maryland

16-18: Summary statistics for metal concentrations in soils at the:

16. Riot-control-agent disposal area, and enrichment factors compared

to average crustal abundances, J-Field, Aberdeen Proving Ground, Maryland

17. Robins Point demolition area, and enrichment factors compared

to average crustal abundances, J-Field, Aberdeen Proving Ground, Maryland

18. Prototype building, and enrichment factors compared to average crustal abundances, J-Field, Aberdeen Proving Ground, Maryland 


\begin{tabular}{|c|c|c|}
\hline Multiply & By & To obtain \\
\hline $\begin{array}{r}\text { foot }(\mathrm{ft}) \\
\text { foot per day }(\mathrm{ft} / \mathrm{d}) \\
\text { mile }(\mathrm{mi}) \\
\text { square foot }\left(\mathrm{ft}^{2}\right) \\
\text { gallon }(\mathrm{gal}) \\
\text { gallons per day per foot }[(\mathrm{gal} / \mathrm{d}) / \mathrm{ft}] \\
\text { foot squared per day }\left(\mathrm{ft}^{2} / \mathrm{d}\right) \\
\text { gallon per day }(\mathrm{gal} / \mathrm{d})\end{array}$ & $\begin{array}{l}0.3048 \\
0.3048 \\
1.609 \\
0.0929 \\
3.785 \\
1.438 \times 10^{-7} \\
0.0929 \\
0.000001438\end{array}$ & $\begin{array}{l}\text { meter } \\
\text { meter per day } \\
\text { kilometer } \\
\text { square meter } \\
\text { liter } \\
\text { meter squared per second } \\
\text { meter squared per day } \\
\text { square meter per second }\end{array}$ \\
\hline
\end{tabular}

Sea Level: In this report, "sea level" refers to the National Geodetic Vertical Datum of 1929--a geodetic datum derived from a general adjustment of the first-order level nets of the United States and Canada, formerly called Sea Level Datum of 1929.

Other abbreviated units of measure: Water temperature, specific conductance, chemical concentration, and other chemical and physical properties of constituents are given in metric units. Water temperature in degrees Celsius $\left({ }^{\circ} \mathrm{C}\right)$ can be converted to degrees Fahrenheit $\left({ }^{\circ} \mathrm{F}\right)$ by use of the following equation:

$$
{ }^{\circ} \mathrm{F}=1.8\left({ }^{\circ} \mathrm{C}\right)+32
$$

Specific conductance of water is expressed in microsiemens per centimeter at 25 degrees Celsius $(\mu \mathrm{S} / \mathrm{cm})$. This unit is equivalent to micromhos per centimeter at 25 degrees Celsius, formerly used by the U.S. Geological Survey.

Chemical concentration in water is expressed in milligrams per liter $(\mathrm{mg} / \mathrm{L})$, parts per million $(\mathrm{ppm})$ (which is virtually the same as milligrams per liter), micrograms per liter $(\mu \mathrm{g} / \mathrm{L})$, milliequivalents per liter (meq/L), or micromoles per liter $(\mu \mathrm{mol} / \mathrm{L})$. Chemical concentration in soils is expressed in milligrams per kilograms $(\mathrm{mg} / \mathrm{kg})$ or in micrograms per gram $(\mu \mathrm{g} / \mathrm{g})$. 


\title{
ABBREVIATIONS AND ACRONYMS
}

\author{
APG: Aberdeen Proving Ground \\ CERCLA: Comprehensive Environmental Response, Compensation, and Liability Act \\ CLP: Contract Laboratory Program \\ CN: $\alpha$-chloroacetophenone, principal Army tear gas agent prior to 1960 \\ CS: O-chlorobenzylmalonitrile, principal Army tear gas agent after 1960 \\ CSM: Chemical Surety Materials \\ DCE: Dichloroethene (can refer to 1,1-DCE or 1,2-DCE) \\ DNAPL: Dense Non-Aqueous Phase Liquid \\ DO: Dissolved oxygen \\ HGA: Hydrogeologic assessment
}

MCL: Maximum Contaminant Level

MIBK: Methyl isobutyl ketone

PCA: Tetrachloroethane (refers to 1,1,2,2-PCA)

PCE: Tetrachloroethene

RC: Riot control agent

RCRA: Resource Conservation and Recovery Act

RI/FS: Remedial Investigation and Feasibility Study

SMCL: Secondary Maximum Contaminant Level

SVOC: Semivolatile organic compounds

TCA: Trichloroethane (can refer to 1,1,2-Trichloroethane)

TCE: Trichloroethene (Trichloroethylene)

USATHAMA: U.S. Army Toxic and Hazardous Materials Agency

USEPA: U.S. Environmental Protection Agency

USGS: U.S. Geological Survey

UXO: Unexploded ordnance

VC: Vinyl chloride

VOC: Volatile organic compound

VX: $\beta$-diisopropylaminoethyl-mercapto-O-ethyl methylphosphonothioate, nerve agent 


\title{
Assessment Of Soil, Surface-Water, And Ground-Water Contamination At Selected Sites At J-Field,
}

\section{Aberdeen Proving Ground, Maryland}

\author{
By Daniel J. Phelan, Lisa D. Olsen, Martha L. Cashel, Judith L. Tegeler, and \\ Elizabeth H. Marchand
}

\begin{abstract}
J-Field is located at the southernmost tip of the Gunpowder Neck Peninsula in the Edgewood Area of Aberdeen Proving Ground, on the western shore of Chesapeake Bay, in Harford County, Maryland. J-Field has been used by the U.S. Army since World War I as a testing ground for munitions, including chemical-warfare agents. From shortly after World War II into the 1970's, chemicalwarfare agents, high-explosive munitions, and industrial chemicals were tested and disposed of at J-Field by open-pit burning and by highexplosive demolition. Only emergency disposal operations have been conducted at J-Field since the early 1980's. Soil, surfacewater, and ground-water contamination has resulted from the migration of unburned chemicals and fuels from the disposal areas. Discharge of contaminants from ground water and runoff has resulted in surface-water contamination in the marshes and ponds in J-Field.

This investigation was conducted from 1989 to 1994 as part of a remedial investigation of J-Field in response to Comprehensive Environmental Response, Compensation, and Liability Act of 1980 (CERCLA) requirements. The nature and extent of contamination was assessed at five sites: the toxic-materials disposal area, the white-phosphorus disposal area, the riotcontrol-agent disposal area, the Robins Point
\end{abstract}

demolition area, and the prototype building area.

The toxic-materials disposal area was the most contaminated of the five sites investigated. Most of the soil- and surfacewater contamination was detected in the marsh area to the east of the disposal pits. High concentrations of lead, antimony, cadmium, copper, and mercury were detected in soils at the edge of this marsh. Lead concentrations as high as 51 micrograms per liter $(\mu \mathrm{g} / \mathrm{L})$ and concentrations of other trace metals were highest in surface water at the edge of the marsh. Volatile organic compounds (VOC's), with concentrations of 1,1,2,2-Tetrachloroethane (PCA) as high as $2,300 \mu \mathrm{g} / \mathrm{L}$, were detected in surface-water samples collected at the edge of this marsh. There was evidence of significant ground-water contamination at the toxic-materials disposal area, particularly in the surficial aquifer in areas adjacent to and downgradient of the disposal pits. In ground water from the surficial aquifer, major contaminants detected included arsenic $(60 \mu \mathrm{g} / \mathrm{L})$, trichloroethene (TCE) $(41,000 \mu \mathrm{g} / \mathrm{L})$, and 1,2Dichloroethene (DCE) $(12,000 \mu \mathrm{g} / \mathrm{L})$. A concentration of $260,000 \mu \mathrm{g} / \mathrm{L}$ of $1,1,2,2-\mathrm{PCA}$ at well JF83 indicated the presence of dense non-aqueous phase liquid (DNAPL) in the surficial aquifer. Ground-water contamination also was detected in the confining unit and in the confined aquifer. The drilling process for 
installation of monitoring wells was the probable source of VOC contamination in wells in the confining unit and the confined aquifer.

The degree of contamination at the whitephosphorus disposal area was significantly lower and less extensive than at the toxicmaterials-disposal area. Soil, surface-water, and ground-water contamination was localized rather than widespread. The major contaminants detected in the surficial aquifer were TCE and lead.

At the riot-control-agent disposal area, lead was the only inorganic compound detected above background levels in soils. Although lead contamination was detected in soils and surface water, it was not detected in ground water at this site. There was no evidence of organic contamination of soils or surface water downgradient of the riot-control-agent disposal area. Benzene, cyanide, and methylisobutyl ketone (MIBK) were detected in the surficial aquifer. Cyanide; 1,1,1-Trichloroethane (TCA); benzene; chloroethane; and phenols were detected in ground water from the confining unit.

At the Robins Point demolition area, slight enrichment of arsenic, copper, and lead was detected but no evidence was detected of organic contamination in the soil samples. In surface-water samples, low concentrations of inorganic constituents were detected, and organic compounds were not detected. There is no indication of inorganic contamination of ground water in the surficial aquifer at this site.

Contamination at the prototype building area was very localized. A soil sampling site next to the building had elevated levels of lead $(93 \mu \mathrm{g} / \mathrm{g})$ and $1,1,1-\mathrm{TCA}(.009 \mu \mathrm{g} / \mathrm{g})$, but with the exception of this site, soils near the prototype building did not appear to be contaminated because of ordnance disposal or testing activities. During the second round of sampling (1992-93), there was no evidence of inorganic or organic ground-water contamination in the vicinity of the prototype building.

\section{Introduction}

J-Field is located at the southernmost tip of the Gunpowder Neck Peninsula in the Edgewood Area of Aberdeen Proving Ground (APG), on the western shore of Chesapeake Bay, in Harford County, Maryland (fig. 1). J-Field has been used by the U.S. Army since World War I as a testing ground for munitions, including chemical-warfare agents. From shortly after World War II into the 1970's, chemical-warfare agents, high-explosive munitions, and industrial chemicals were tested and disposed of at J-Field by open-pit burning and by high-explosive demolition. Only emergency disposal operations have been conducted at J-Field since the early 1980's. Soil, surface-water, and ground-water contamination has resulted from the migration of unburned chemicals and fuels from the disposal areas. Discharge of contaminants from ground water and runoff has resulted in contamination of the marshes and ponds in J-Field, which has created a potential for adverse effects on wildlife and aquatic populations in the area (Hughes, 1993).

In 1977-78, soil and ground-water contamination at J-Field was identified during an environmental survey of the Edgewood Area conducted by the U.S. Army Toxic and Hazardous Materials Agency (USATHAMA) (Nemeth and others, 1983). As a result of this investigation, the U.S. Environmental Protection Agency (USEPA) issued a Resource Conservation and Recovery Act (RCRA) permit (MD3-21-002-1355) in 1986 that required a hydrogeologic assessment at J-Field.

In May 1987, at the request of the Environmental Management Office of APG, the U.S. Geological Survey (USGS) began data collection for the hydrogeologic assessment (HGA). The HGA involved determination of the hydrogeologic framework and characterization of the extent and migration of contaminants in the vicinity of disposal sites, which are referred to as "solid-waste-management units" (SWMU's). The SWMU's at J-Field include the toxic-materials disposal area, the white-phosphorus disposal area, the riot-control-agent disposal area, the prototype building, and the South Beach demolition area. 


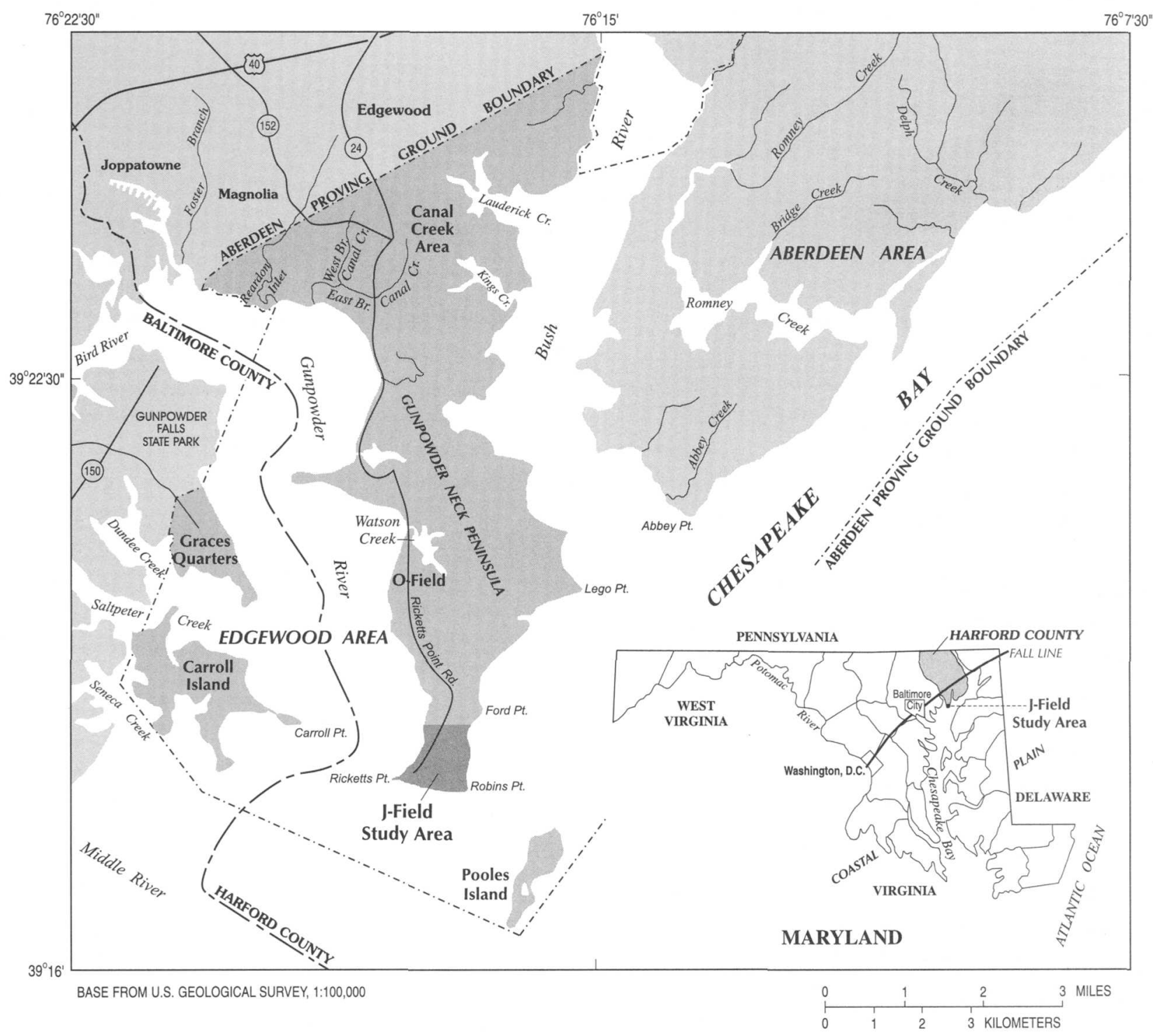

Figure 1. Location of J-Field study area, Aberdeen Proving Ground, Maryland (modified from Hughes, 1993). 
The South Beach demolition area is now (1997) submerged because of shoreline erosion. An observation-well network was installed during the data-collection phase of the investigation to determine directions and rates of ground-water flow. This network was utilized along with the surface-water and soil-sampling networks to determine the concentration and spatial distribution of contaminants at J-Field.

In 1990, the entire Edgewood Area of APG was added to the National Priority List (NPL) by the USEPA, placing it under the regulations and guidelines of the Comprehensive Environmental Response, Compensation, and Liability Act of 1980 (CERCLA), also known as Superfund.

The investigation that is the subject of this report was conducted from 1989 to 1994 as part of a remedial investigation of $\mathrm{J}$-Field in response to CERCLA requirements. The ground-waterquality data for this investigation were collected in two phases: Phase I data were collected in 1990, and Phase II data were collected during 1992-93. During Phase I, preliminary determinations were made of the type and extent of contamination in ground water. During Phase II, the extent of contamination was further delineated and sampling was performed in areas where gaps were identified during analysis of Phase I data. Soil-quality data were collected in 1991 and surface-water-quality data were collected in 1993.

\section{History of Site Testing and Disposal Activities}

Because detailed records of the location and nature of chemical-warfare agent tests performed at J-Field are not available, it is not possible to compile a summary of the quantities of chemicals released. Nemeth (1989) provides information on each chemical agent that may have been disposed of at J-Field, and suggests that because the chemical-agent tests were of such a small scale, there is little possibility of residual environmental contamination by these materials.

Between 1940 and 1970, open-pit burning at J-Field was used extensively to dispose of many types of chemical agents, high explosives, and chemical wastes. Although no records were kept of the quantities and types of chemicals and agents that were disposed of by open-pit burning, they probably included various nerve agents [such as VX ( $b$-diisopropylaminoethyl-mercapto-O-ethyl methylphosphonothioate), arsenicals (such as adamsite and lewisite), riot-control agents (such as CS (O-chlorobenzylmalonitrile), which was the principal Army tear gas agent after 1960, and CN (alpha-chloroacetophenone), which was the principal Army tear gas agent prior to 1960), and mustards (Nemeth and others, 1983). Munitions containing these agents, white phosphorus, and high explosives also were disposed of at J-Field. Nerve agents may have been neutralized with chlorine bleach or sodium hydroxide before burning. Chemical wastes were primarily generated from the industrial production of chemical-warfare agents at APG and probably consisted of organic solvents. Other materials disposed of at J-Field were napalm, liquid-smoke materials, and agentcontaminated storage or manufacturing materials (Nemeth and others, 1983).

The typical procedure for open-pit burning was to place wood dunnage in the disposal pit, add the agents, munitions, and other chemical wastes, and then flood the pit with a hydrocarbon fuel, such as fuel oil. The fuel was ignited and the containers were opened simultaneously by an explosive charge. After the burn was completed, the remaining materials were moved to the adjacent re-burn pit where the process was repeated. After completion of the second burn, any remaining debris was pushed into the adjacent marsh. Some of the liquid materials, such as fuels, organic solvents, and agents probably infiltrated into the soil causing soil and ground-water contamination (Nemeth, 1989).

Disposal of hazardous materials was primarily conducted in three SWMU's at J-Field: the toxicmaterials disposal area, the white-phosphorus disposal area, and the riot-control-agent disposal area (fig. 2). These SWMU's are described in detail in Nemeth and others (1983) and Nemeth (1989). Since the 1970's, the pits at the toxicmaterials and white-phosphorus disposal areas have been blocked by mounds of soil to prevent drainage to adjacent surface-water bodies. Water that collects in the pit at the riot-control-agent disposal area presently (1997) drains into the tidal Gunpowder River. 


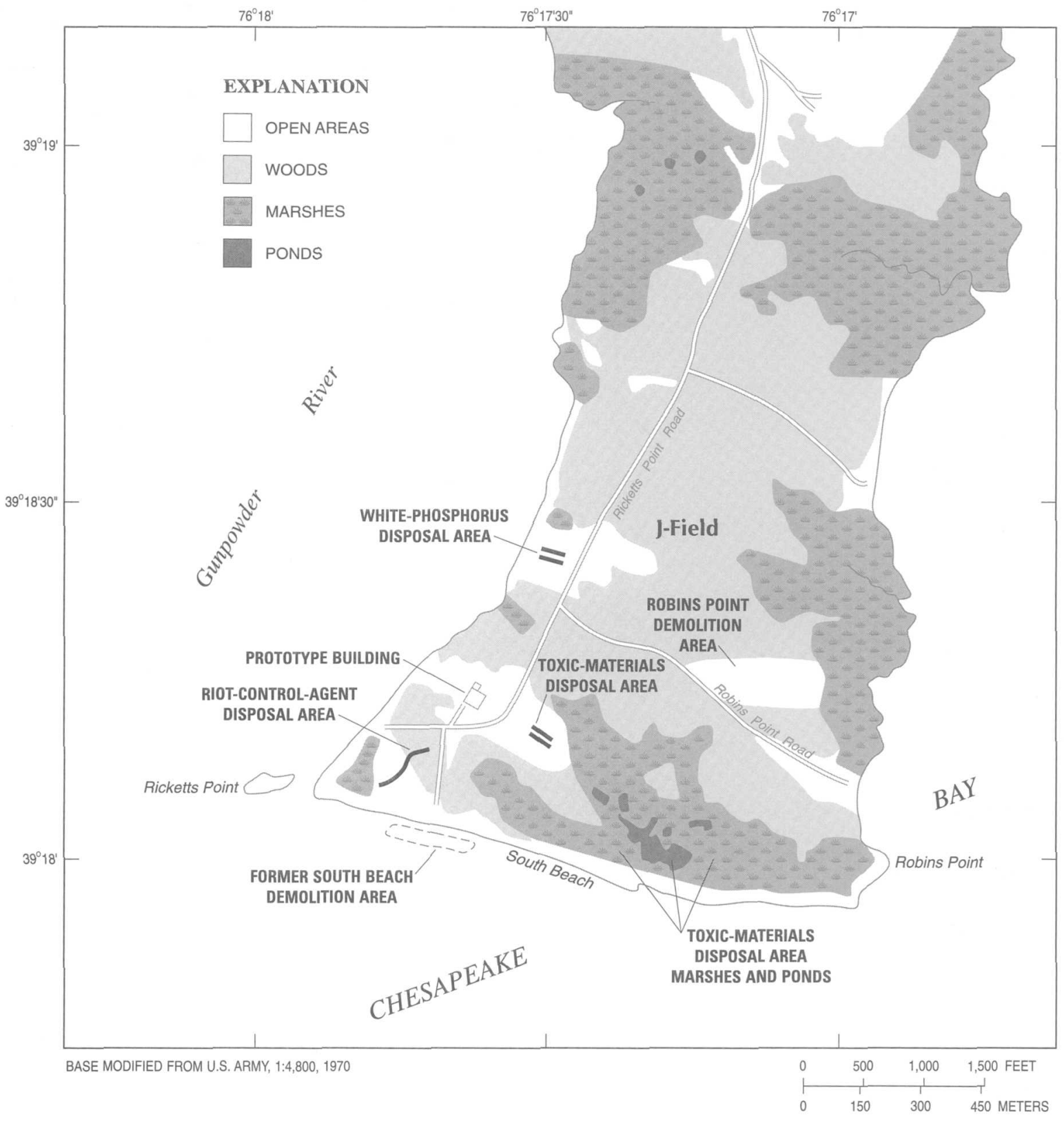

Figure 2. Location of solid-waste management units, the prototype building, South Beach, and land-cover types at J-Field, Aberdeen Proving Ground, Maryland (modified from Hughes, 1993). 
Since about 1970, unexploded ordnance discovered during excavations at APG and laboratory chemicals from small-scale testing have been detonated at J-Field, primarily at the Robins Point demolition area (fig. 2), but also at the whitephosphorus disposal area. The procedure involves detonation of the ordnance or laboratory vial with enough high explosives to destroy the chemicals in the resulting fireball.

The prototype building (fig. 2) is a three-story, steel-reinforced, open concrete structure that was probably used to store chemicals although there are no records of such use (Hughes, 1993). The building was designed to simulate typical German construction practices during World War II and was used to test the effectiveness of various weapons on such structures. Numerous circular stains on the concrete floor of the building probably resulted from storage drums. There are no pits or other obvious signs of disposal activities in the immediate vicinity of the prototype building.

The South Beach demolition area was used primarily to detonate high-explosive munitions. Because of rapid rates of shoreline erosion, the South Beach demolition area is now submerged, and, therefore, will not be addressed in this report. Its presence is marked only by numerous munitions fragments that can be observed at low tide.

\section{Previous Investigations}

The first environmental survey of J-Field was conducted during $1977-78$ by USATHAMA (Nemeth and others, 1983). The study involved a search of available records of disposal activities, collection of hydrogeologic data, and chemical analyses of soil, sediment, surface water, and ground water. Wells installed for the study were screened from approximately 8 to $18 \mathrm{ft}$ below land surface. Nemeth and others (1983) concluded that deposits of interbedded sand and clay encountered during test-hole drilling were from the Cretaceous Potomac Group. Water levels measured in observation wells indicated that ground-water flow was from the upland areas toward the adjacent rivers or wetlands, and that the water table generally followed the land-surface topography. No contaminants were detected in soil samples, in sediment samples from boreholes, or in surface-water samples, although low concentrations of volatile organic compounds (VOC's) were detected in ground-water samples. Nemeth and others (1983) concluded that the levels of contaminants at J-Field were not a threat to the environment and that future monitoring was not necessary.

The environmental effects of the munitions: disposal operations at J-Field were reevaluated in 1983 by Princeton Aqua Science (1984). The study involved site inspections, interviews with appropriate site-operations personnel, and field investigations. Sediment samples were collected from boreholes and analyzed for chemical constituents. At the toxic-materials disposal area, the borehole sediment samples contained levels of arsenic, cadmium, lead, and mercury that were higher than those in adjacent areas. After nine observation wells were installed, ground-water samples were collected and analyzed for chemical constituents. At the toxic-materials disposal area, concentrations of nitrate, coliform bacteria, and gross-beta radiation in the ground water exceeded the 1983 USEPA maximum contaminant levels (MCL's). Secondary maximum contaminant levels (SMCL's) for chloride, iron, manganese, and sulfate also were exceeded. At the whitephosphorus disposal area, the MCL for coliform bacteria and the SMCL's for iron and sulfate were exceeded. The study, however, concluded that the burning operations were not adversely affecting ground-water quality and that the disposal practices did not need to be substantially altered (Princeton Aqua Science, 1984).

The most comprehensive information available on the disposal of chemicals at J-Field and a review and summary of previous work at the site is provided in the RCRA Facility Assessment by Nemeth (1989). On the basis of contaminants detected in ground water, Nemeth (1989) recommended further investigations at the toxic-materials disposal area, the white-phosphorous disposal area, the riotcontrol-agent disposal area, the prototype building area, and the South Beach area.

The hydrogeology and results of soil-gas sampling at J-Field are presented in Hughes (1993). The sequence of Coastal Plain sediments beneath J-Field was identified as Cretaceous fluvial deposits overlain by Pleistocene paleochannel deposits. The thickness and distribution of the hydrogeologic units were mapped on the basis of 42 wells drilled for this study-- 16 in the surficial aquifer, 12 in the confining unit of the Talbot 
Formation, 12 in the confined aquifer of the Talbot Formation, and 2 in a confined aquifer of the Patapsco Formation. The hydrogeologic units were mapped offshore by continuous seismicreflection profiling. In the shallow flow system, ground water flows from upland recharge areas toward discharge areas in the wetlands, the tidal Gunpowder River, and the Chesapeake Bay. Soilgas samples showed high relative-flux values for chlorinated solvents, alkanes, phthalates, and aromatic hydrocarbons at the toxic-materials disposal area, the white-phosphorus disposal area, and the riot-control-agent disposal area, indicating that ground-water contaminants are moving from source areas beneath the disposal pits toward discharge points in the marshes and estuaries (Hughes, 1993).

The effects on ground-water flow and movement of contaminants, and overall effectiveness of several remedial actions were simulated with a steady-state ground-water-flow model by Hughes (1995). The simulated remedial actions included installation of (1) an impermeable cover, (2) barriers to horizontal flow, (3) extraction wells, and (4) barriers to horizontal flow in combination with extraction wells. These remedial actions were simulated at the toxic-materials disposal area and the riot-control-agent disposal area but not at the white-phosphorous disposal area because of low concentration and limited distribution of contaminants.

As part of the CERCLA remedial investigation, the USGS collected hydrogeologic, soil-gas and soil-quality data, and water-quality data at J-Field from 1989 to 1994. Data from that investigation, including comprehensive data tables and an evaluation of the quality-assurance data, are presented in Phelan and others (1996), which is a companion report to this report.

\section{Purpose and Scope}

The purpose of this report is to assess the nature and extent of contamination in the soil, surface water, and ground water due to disposal of chemical-warfare agents, high-explosive munitions, and industrial chemicals at five sites at J-Field. On the basis of previous work, the toxicmaterials disposal area, the white-phosphorus disposal area, and the riot-control-agent disposal area were' known to be contaminated, and the
Robins Point demolition area and the prototype building area were suspected of being contaminated. Interpretations presented in this report are based on analyses of water and soil samples collected between 1989 and 1994, and on the hydrogeology as determined by Hughes (1993). Information from this study will be used to support a Remedial Investigation and Feasibility Study (RI/FS) for J-Field.

The scope of work included collection and analyses of ground-water, soil-, and surface-water samples. The ground-water-quality data for this investigation were collected in two phases: Phase I data were collected in 1990, and Phase II data were collected during 1992-93. During Phase I, preliminary determinations were made of the type and extent of contamination in the ground water. Fifty-five wells were sampled during the summer of 1990. During Phase II, the extent of contamination was further delineated and sampling was performed in areas where gaps were identified during analysis of Phase I data. A total of 48 wells were sampled between November 1992 and January 1993. The chemical quality of soil at J-Field was sampled at 36 sites during April 11-16, 1991. Twenty surface-water sites were sampled in the spring of 1992 . In the fall of 1992 , the same 20 sites were revisited, but because of seasonal water-level declines, samples could only be obtained at 5 of the sites.

\section{Description of Study Area}

J-Field is located at the southernmost tip of the Gunpowder Neck Peninsula (fig. 1). The topography is relatively flat. Along the west-central part of the study area, north-south trending uplands approximately 10 to $15 \mathrm{ft}$ above sea level slope gently toward the shores of the surrounding estuaries or marshes. Tidal estuaries border J-Field on three sides--the tidal Gunpowder River on the west, and the Chesapeake Bay to the south and east (fig. 2). Land cover at J-Field includes open fields, second-growth forests, forested wetlands, and tidal and nontidal marshes (fig. 2). The marsh that lies south and east of the toxic-materials disposal area (fig. 2) is nontidal and is preserved by a sandbar as narrow as 15- $\mathrm{ft}$ wide at times of high tide in the Chesapeake Bay and times when water levels are high in the marsh. This sandbar is apparently 
stabilized by the root system of the abundant Phragmites grasses.

This report focuses on five sites at J-Field: the toxic-materials disposal area, the white-phosphorus disposal area, the riot-control-agent disposal area, the Robins Point demolition area, and the prototype building (fig. 2). The areas immediately surrounding the toxic-materials and white-phosphorus disposal areas are clear of trees and brush and are usually mowed twice a year. At both of these disposal areas, there are two parallel disposal pits that are approximately $15-\mathrm{ft}$ apart. Each pit originally was up to $10-\mathrm{ft}$ deep and was approximately $200-\mathrm{ft}$ long by 15 -ft wide. At the toxicmaterials disposal area, remnants of older pits extend approximately $100 \mathrm{ft}$ into the marsh southeast of the existing pits. The riot-control-agent disposal area is in a wooded area and contains a single pit approximately $500-\mathrm{ft}$ long. All of the pits were originally designed so that any precipitation that collected in them would drain into an adjacent marsh or river. The disposal pits at the toxic-materials disposal area and the whitephosphorus disposal area, however, have been blocked by mounds of soil since the 1970's to prevent drainage. At the riot-control-agent disposal area, water that collects in the pit drains into the tidal Gunpowder River. The Robins Point demolition area is near the southeastern tip of $\mathrm{J}$-Field, and is where most emergency ordnancedisposal activities for the Edgewood Area of APG take place. There are no known disposal pits or past chemical disposal activities in the Robins Point area. The prototype building is surrounded by a large open field. There are no pits or other signs of disposal activities in the immediate vicinity of the prototype building.

\section{Acknowledgments}

The authors thank John Wrobel and Gerald Garcia of the Directorate of Safety Health and Environment of APG for providing logistical support. Maynard W. Geisler and Kenneth S. Deptol, APG safety technicians at Range Control, are thanked for their courtesy and care in controlling and coordinating site access for all work at J-Field. The authors also thank Peter Pritchard and Walter Von cannon of the Aberdeen Test Center for logistical support during field work. The authors thank Louis Martino of Argonne National
Laboratory (ANL), whose help with coordination of data-collection efforts among the USGS, ANL, and contractors at the site was crucial to this study. Roxanne Diehl of the U.S. Army Environmental Center and Robert Brown of Potomac Research are thanked for extensive data retrievals. Julie Kramer and Karen German of Quanterra Laboratories also are thanked for assistance with data retrievals. The authors thank Dorothy Tepper, Cherie Miller, James Gerhart, Dorothea Hanchar, Leon Joseph. Bachman, and Joel Dysart of the U.S. Geological Survey for their helpful reviews of the manuscript. The Publications Section of the MarylandDelaware-District of Columbia District of USGS is thanked for assisting in editing the report and drafting the illustrations.

\section{Geologic Setting}

The study area is located within the Atlantic Coastal Plain Physiographic Province. This province is characterized by a wedge of unconsolidated sediments composed of heterogeneous layers of sand, silt, and clay that dip and thicken to the southeast.

Between November 1995 and April 1996, a corehole was drilled to bedrock at Robins Point as part of a regional study to determine the extent of confining units and to further define the regional hydrogeology. Detailed lithologic descriptions of the Coastal Plain sediments encountered in this corehole are provided in Powars (1997). Paleozoic weathered metamorphic rock is at the top of rock at a depth of $888 \mathrm{ft}$ below land surface. Cretaceous deposits of the Potomac Group include the aquifers and confining units of the Patuxent Formation at 647 to $888 \mathrm{ft}$ below land surface, and the Patapsco Formation at 177 to $647 \mathrm{ft}$ below land surface. The Pleistocene deposits include the confined aquifer of the Talbot Formation at 132 to $177 \mathrm{ft}$ below land surface, and the confining unit of the Talbot Formation at 31 to $132 \mathrm{ft}$ below land surface. The surficial aquifer, from land surface to $31 \mathrm{ft}$, is composed of Holocene sediments.

The sediments that make up the Potomac Group were deposited in a complex river system consisting of channels, flood plains, and cutoffmeander swamps (Minard and others, 1980). The Patapsco Formation was deposited in a fluvial environment (Hughes, 1995). The individual beds within the Patapsco Formation at J-Field are, for 
the most part, laterally discontinuous and variable in thickness (Hughes, 1993). The Talbot

Formation is a complex sequence of fluvial and estuarine sediments that were deposited in a Pleistocene paleochannel (Hughes, 1991; Powars, 1997). The geology and mineralogy of geologic units within the unconsolidated sequence are described in more detail in Hughes (1993) and Powars (1997).

\section{Hydrologic Setting}

The shallow ground-water and surface-waterflow systems at J-Field are somewhat independent of conditions elsewhere on the Gunpowder Neck Peninsula because the shallow ground-water-flow system is controlled by a northeast-southwest trending paleochannel (Hughes, 1991) (fig. 3), and no nontidal streams flow into J-Field from surrounding areas. The tidal Gunpowder River, Chesapeake Bay, and tidal marshes surround J-Field (fig. 2).

\section{Ground-Water-Flow System}

This study focuses on the surficial aquifer, the confining unit, and the confined aquifer--the three major hydrogeologic units within the Talbot Formation. Ground water in the shallow flow system at J-Field flows from recharge zones in the upland areas toward discharge zones in adjacent wetlands, streams, or estuaries. Generalized directions of ground-water flow are shown in figure 4.

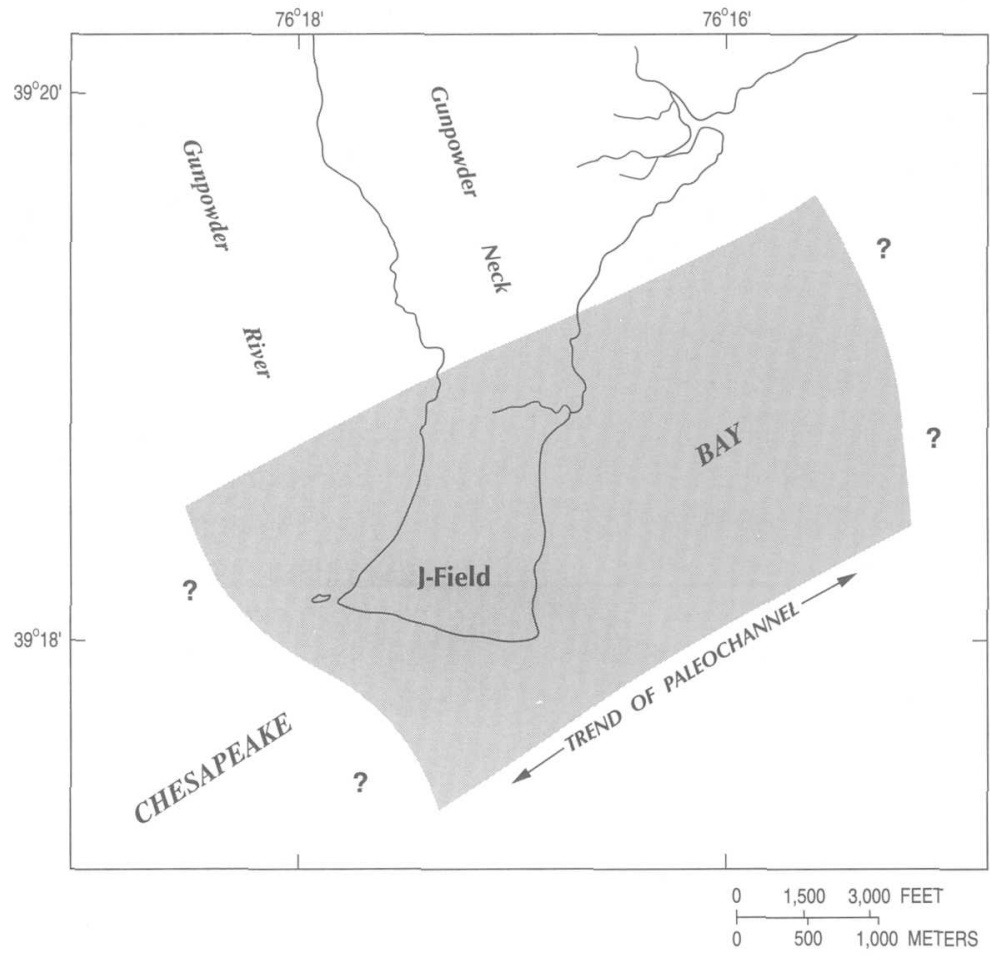

EXPLANATION

AREA UNDERLAIN BY PALEOCHANNEL (Queried where uncertain)

Figure 3. Estimated extent of paleochannel deposits at J-Field, Aberdeen Proving Ground, Maryland (modified from Hughes, 1993). 


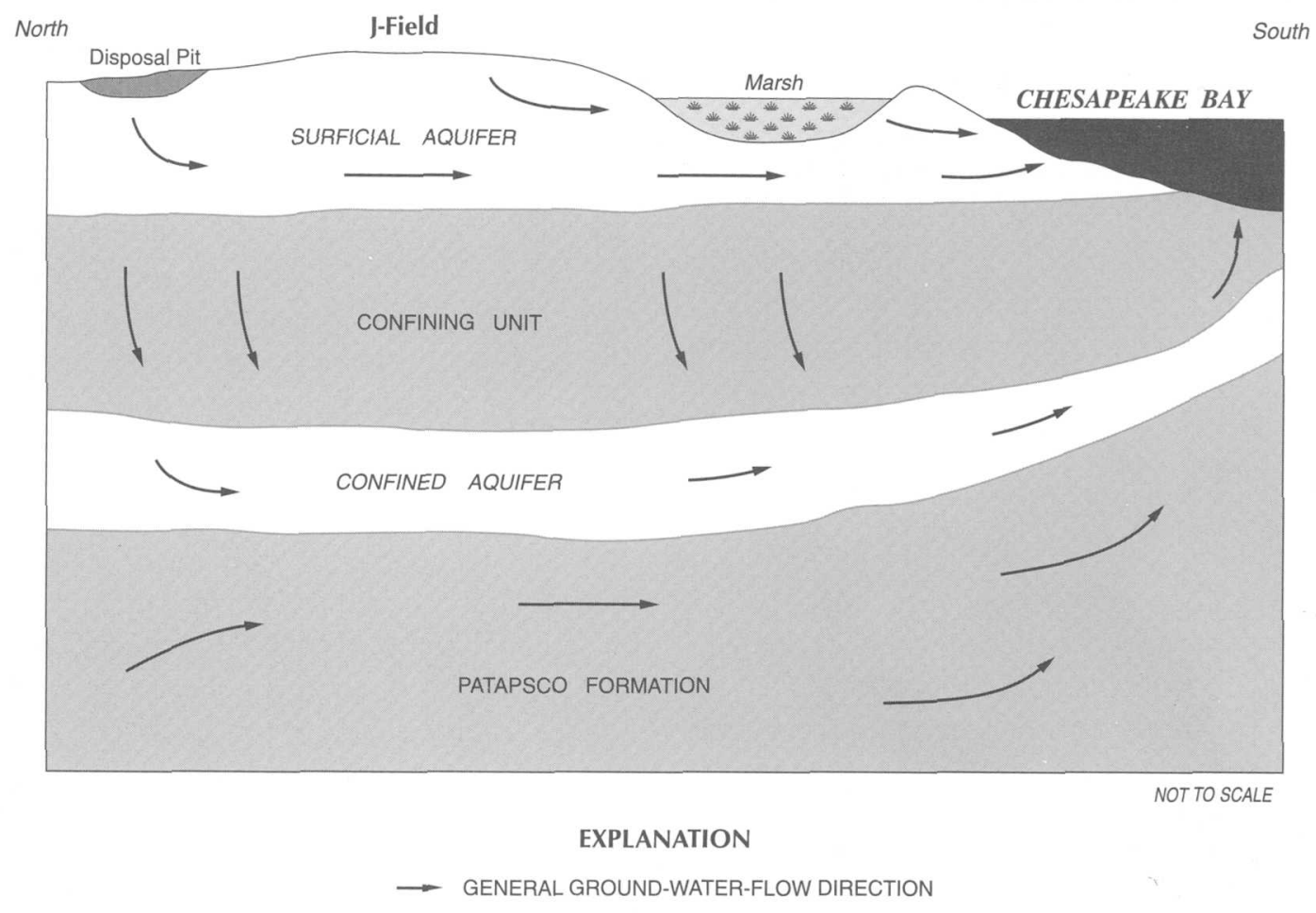

Figure 4. Hydrogeologic units and general ground-water-flow direction in the J-Field area, Aberdeen Proving Ground, Maryland (from Hughes, 1995).

The surficial aquifer, which is approximately 30 to $40-\mathrm{ft}$ thick, is composed of marginal marine sediments consisting of medium-grained to finegrained sand with interbedded clay (Hughes, 1995). Individual sand and clay beds range from 2 to 10 -ft thick and are laterally discontinuous (Hughes, 1995). Hydraulic head and groundwater-flow directions in the surficial aquifer in November 1989 are shown in figure 5.

The surficial aquifer is recharged by precipitation that percolates downward to the water table. Although a small fraction of ground water in the surficial aquifer percolates slowly downward through the confining unit to the confined aquifer (Hughes, 1993), most of the ground water flows laterally toward discharge areas in the adjacent marshes and estuaries.

The hydraulic conductivity of the surficial aquifer, as determined by slug tests, ranges from 0.29 to $1.04 \mathrm{ft} / \mathrm{d}$, with a median value of $0.69 \mathrm{ft} / \mathrm{d}$ (Hughes, 1993). The hydraulic conductivity of the surficial aquifer is so low that the aquifer could be classified as Type III (not a viable source of drinking water) according to Maryland Department of the Environment regulations (Maryland Department of the Environment, 1988). Assuming a maximum aquifer thickness of $40 \mathrm{ft}$ and a maximum hydraulic conductivity of $1.04 \mathrm{ft} / \mathrm{d}$, the maximum transmissivity of the surficial aquifer at $\mathrm{J}$-Field is $41.6 \mathrm{ft}^{2} / \mathrm{d}$, which is well below the minimum transmissivity of $133 \mathrm{ft}^{2} / \mathrm{d}$ for Type I aquifers in Maryland.

The confining unit that underlies the surficial aquifer ranges in thickness from 40 to $110 \mathrm{ft}$ (Hughes, 1995). This confining unit is of estuarine origin and consists of silty, sandy clay. 


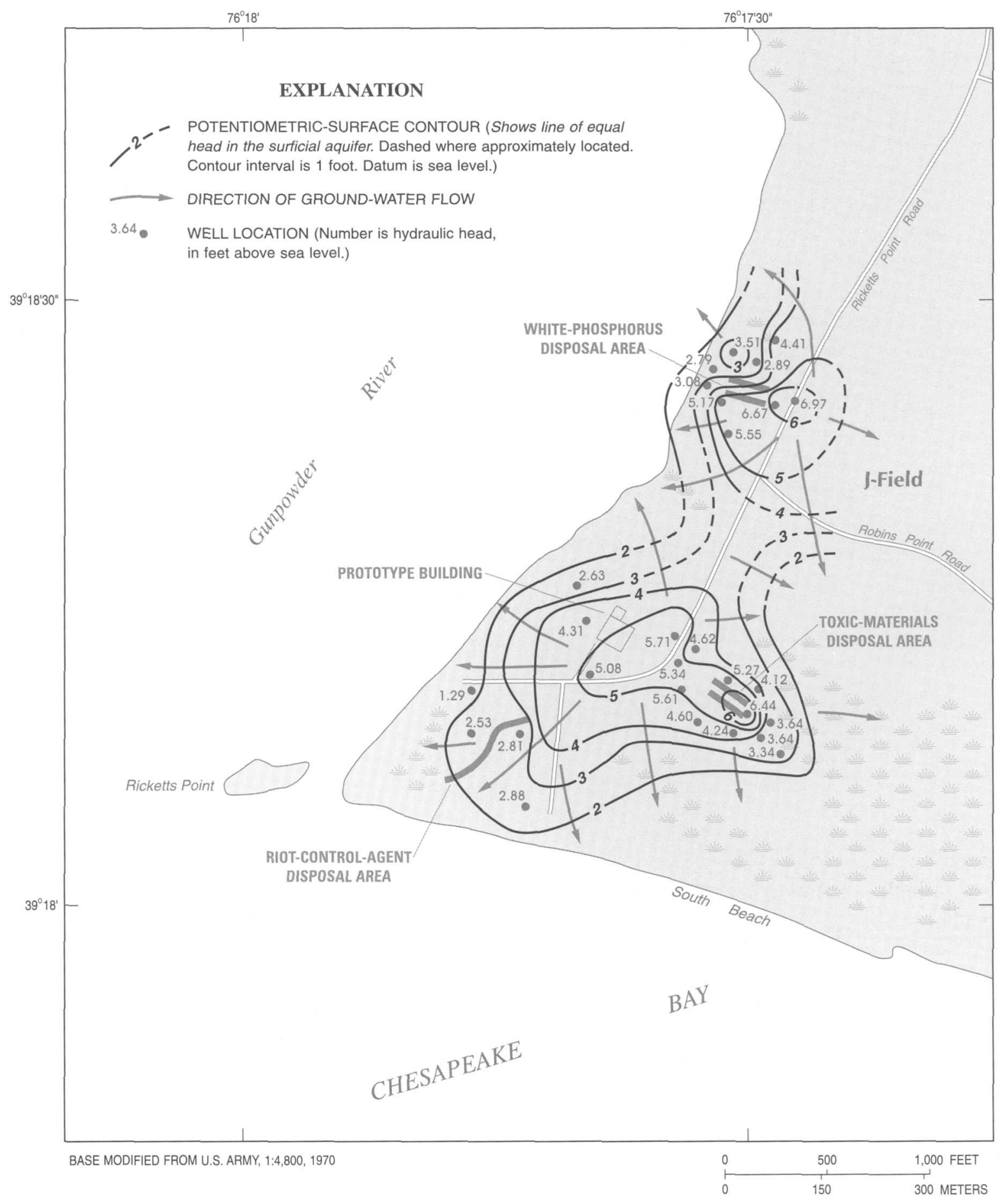

Figure 5. Hydraulic head and direction of ground-water flow in the surficial aquifer, November 1989, J-Field, Aberdeen Proving Ground, Maryland (from Hughes, 1993). 
The sand is very fine grained and composes less than 30 percent of the confining unit. Although only trace amounts of bivalve shells and shell fragments are present in the upper part of this unit, they make up as much as 70 percent of the unit in some sections near its base. Fine-grained organic particles are present in minor amounts in some zones but leaves, stems, and large woody fragments compose up to 75 percent of other zones. Water-level elevations in the confining unit are typically between those measured in the surficial and confined aquifer wells, but water-level elevations in the confining unit may exceed those in the adjacent aquifers, particularly during the dry season in late summer. A head gradient of as much as $6 \mathrm{ft}$ between the surficial aquifer and the confined aquifer indicates that the confining unit appreciably slows the movement of water between the two units (Hughes, 1995). The main component of flow in the confining unit is generally downward toward the confined aquifer. The horizontal hydraulic conductivity of the confining unit, on the basis of slug tests, ranges from less than 0.01 to $0.20 \mathrm{ft} / \mathrm{d}$, with a median of $0.05 \mathrm{ft} / \mathrm{d}$ (Hughes, 1993).

The confined aquifer, which underlies the confining unit, ranges from 40 to 50 thick and consists primarily of gravelly sand mixed with abundant clay and clayey sand (Hughes, 1995). This confined aquifer is of fluvial origin and contains sediment derived from local sources in the Piedmont Province or from the ancestral Susquehanna River Basin (Hughes, 1993). The direction of flow is affected by pressure loading because of tides, but the net flow generally radiates from the topographic highs near Ricketts Point Road toward the Gunpowder River and the Chesapeake Bay on all sides of the peninsula, with the exception of the white-phosphorus disposal area where the flow is to the east, as shown in figure 6 (Hughes, 1993). The hydraulic conductivity of the confined aquifer, on the basis of slug tests, ranges from 3 to $900 \mathrm{ft} / \mathrm{d}$, depending on the amount of fine material present (Hughes, 1993). Where an abundance of silt and clay are present, the median horizontal hydraulic conductivity is $10.5 \mathrm{ft} / \mathrm{d}$; where the aquifer contains only minor amounts of fine material, the median is $390 \mathrm{ft} / \mathrm{d}$ (Hughes, 1993).

\section{Surface-Water-Flow System}

The surface-water-flow system at J-Field includes tidal and nontidal marshes, wetlands, and small tidal streams. The surface-water divide between the tidal Gunpowder River and the Chesapeake Bay is approximately delineated by Ricketts Point Road (fig. 1). There are several ponds at J-Field, and the largest pond is located in the marsh southeast of the toxic-materials disposal area (fig. 2).

The marsh and pond to the east and south of the toxic-materials disposal area are nontidal, and are the primary receptors of ground-water discharge from the surficial aquifer and of surface runoff from the toxic-materials disposal area. Washover from the Chesapeake Bay during storms is a secondary source of water for the marsh. During the spring, the water level in the marsh in the toxicmaterials disposal area is usually about $2 \mathrm{ft}$ higher than high tide in the surrounding estuary, but in the summer the water level of the marsh drops below that of the bay. This could allow ground-water flow from the marsh toward the bay in the spring, and from the bay toward the marsh in the fall. Surface-water runoff from the white-phosphorus disposal pits and the riot-control-agent pits discharges into the Gunpowder River and the Chesapeake Bay.

Tidal waters in the study area include the Gunpowder River, the Chesapeake Bay, small streams bordering J-Field, and most marshes other than the marsh in the toxic-materials disposal area. The tidal creeks at J-Field do not drain any of the SWMU's and, therefore, were not investigated during this study.

\section{Methods Of Investigation}

The following sections describe methods for collection and analysis of the soil-quality, surfacewater, and ground-water samples. These methods are described in detail in Phelan and others (1996). Methods of soil-gas sample collection for the 1989-90 sampling rounds are described in Hughes (1993). The numbering systems for all wells and environmental samples are described below. A section is included on evaluation of the qualityassurance data. 


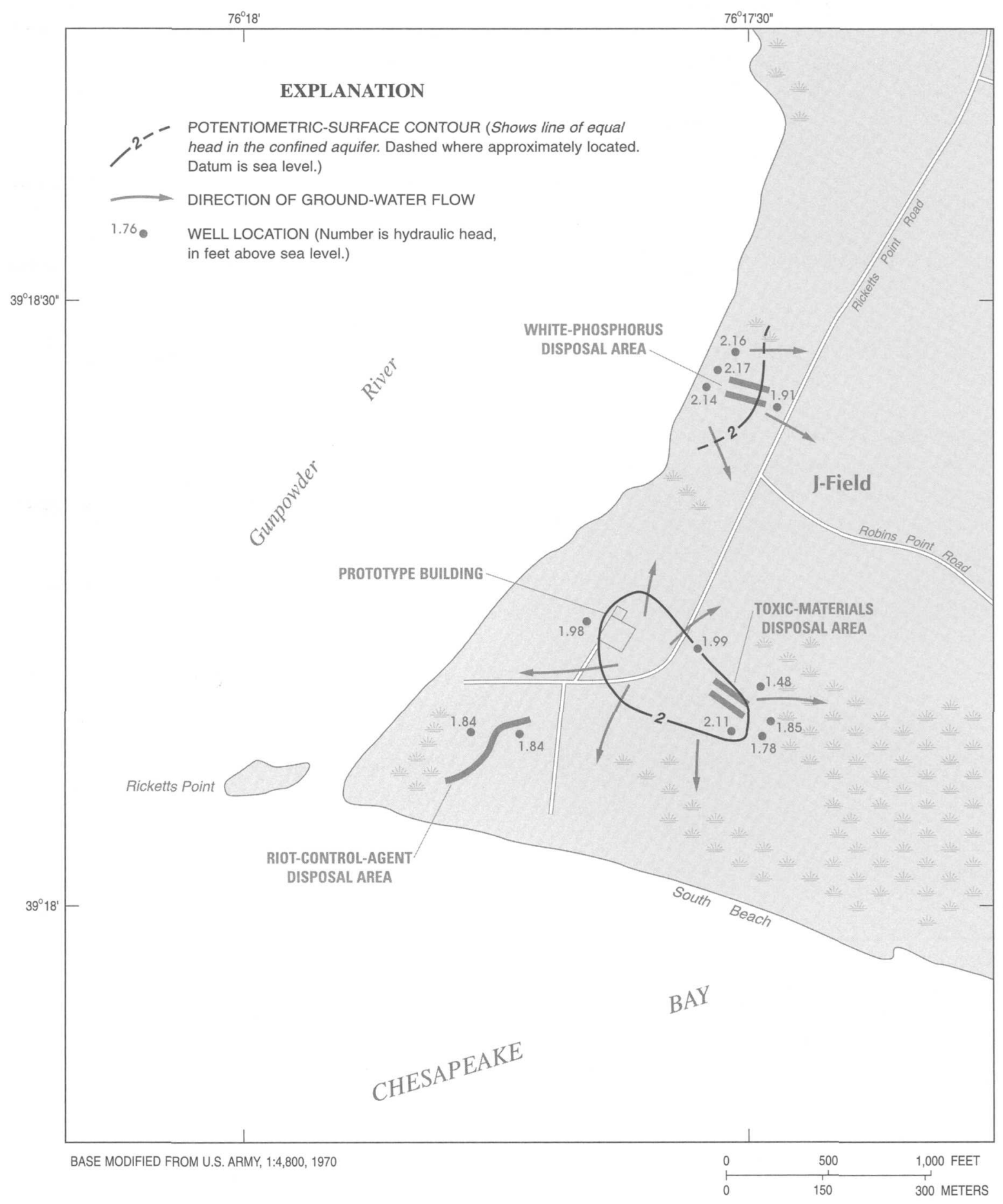

Figure 6. Hydraulic head and direction of ground-water flow in the confined aquifer, November 1989, J-Field, Aberdeen Proving Ground, Maryland (from Hughes, 1993). 


\section{Sample Collection}

Phase I ground-water samples were collected in May and June of 1990. Soil samples were collected in April 1991. Surface-water samples were collected during April and September of 1992. Phase II ground-water samples were collected from November 1992 to January 1993.

\section{Soils}

Analyses of the type, distribution, and relative abundance of organic compounds in soil gas can aid in locating the greatest concentrations of organic contaminants in ground water and soil (Hughes, 1993). Soil-gas samples were collected by Hughes (1993) using a static technique; this technique and the results are described in detail in Hughes (1993). The results of these analyses only can be used to determine areas of greatest soil-gas contamination rather than the actual concentration of contaminants in soil or ground water. The technique is more sensitive to detecting some compounds than others (Hughes, 1993). The first set of soil-gas samples was collected and analyzed in April 1989 and was used as a screening tool to locate sites to drill observation wells and to identify possible areas of soil contamination. Additional observation wells were drilled in the summer of 1989. A second set of soil-gas samples were collected in April 1990 to better define the extent of organic contamination in the soils and ground water (Hughes, 1993).

Sites where soil-quality samples were collected in April 1991 are shown in figure 7. Samples were taken upgradient, downgradient, and near each of the five areas described in this report. A total of 40 samples were collected at 36 sites (a sample was not collected at site 35). Samples from sites 8, 12, 18 , and 27 were actually duplicate samples from sites $7,11,17$, and 26 . Soil-sampling sites were surveyed and checked with magnetometers to ensure safety from unexploded ordnance. A shallow (6-in. deep and approximately 1 - $\mathrm{ft}$ wide) hole was dug at each site with a stainless-steel shovel, and surface debris was removed. Soil samples were promptly taken from the bottom of the hole, placed into three 40-milliliter (mL) amber glass vials and tightly capped. These samples were later analyzed for VOC's and semivolatile organic compounds (SVOC's). The soil in the bottom of the hole was then homogenized by mixing in place. A $250-\mathrm{mL}$ and 1-L sample bottle were filled with the homogenized soil for inorganic analyses. All samples were packed on ice and shipped by overnight express to the laboratory in Cambridge, Massachusetts.

\section{Surface Water}

Surface-water samples were collected in April 1993 from 20 sites (fig. 8) and were analyzed for inorganic and organic constituents. Most of the sites were in shallow marshes or other low-lying areas of ponded water but site 20 was in the Chesapeake Bay, south of the toxic-materials disposal area marsh, and sites 14 and 15 were in the toxic-materials disposal area pond. These same 20 sites were to be sampled again in September 1993, but because of seasonal water-level declines, only 5 of the original sites contained water.

Surface-water samples were collected by submerging the sample bottles in the surface-water body and capping them while still underwater. All samples were unfiltered and were analyzed for total (suspended plus dissolved) concentrations. Specific conductance, $\mathrm{pH}$, water temperature, dissolved oxygen, and alkalinity were measured in the field.

\section{Ground Water}

In 1989, 38 observation wells were drilled as part of this study and were used in conjunction with 19 existing wells to establish a water-level and ground-water-quality sampling network (fig. 9). An additional four wells (JF133, 143, 153, and 163) were drilled in the surficial aquifer in 1992. Methods used for drilling and construction of the wells, the numbering system for the wells, and the sampling methods are described in the following sections.

Ground-water samples were collected from 55 wells during May-June 1990 (Phase I), and from 48 wells during December 1992 and January 1993 (Phase II). All environmental samples were analyzed for VOC's, SVOC's, polychlorinated biphenyls (PCB's), pesticides, and metals. Selected samples also were analyzed for explosive compounds, chemical-warfare-agent degradation 


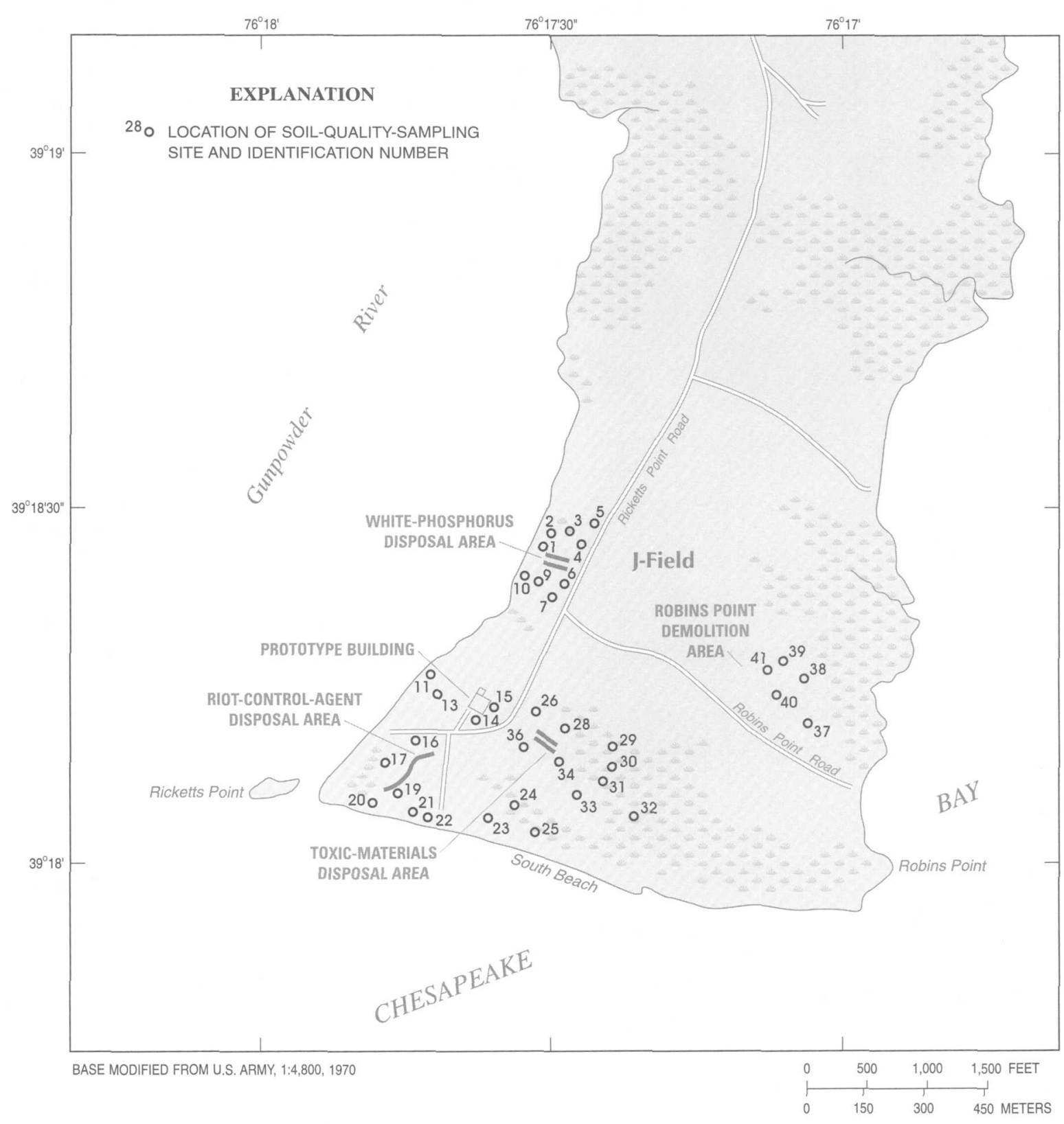

Figure 7. Location of soil-quality-sampling sites, April 1991, J-Field, Aberdeen Proving Ground, Maryland (from Phelan and others, 1996). 


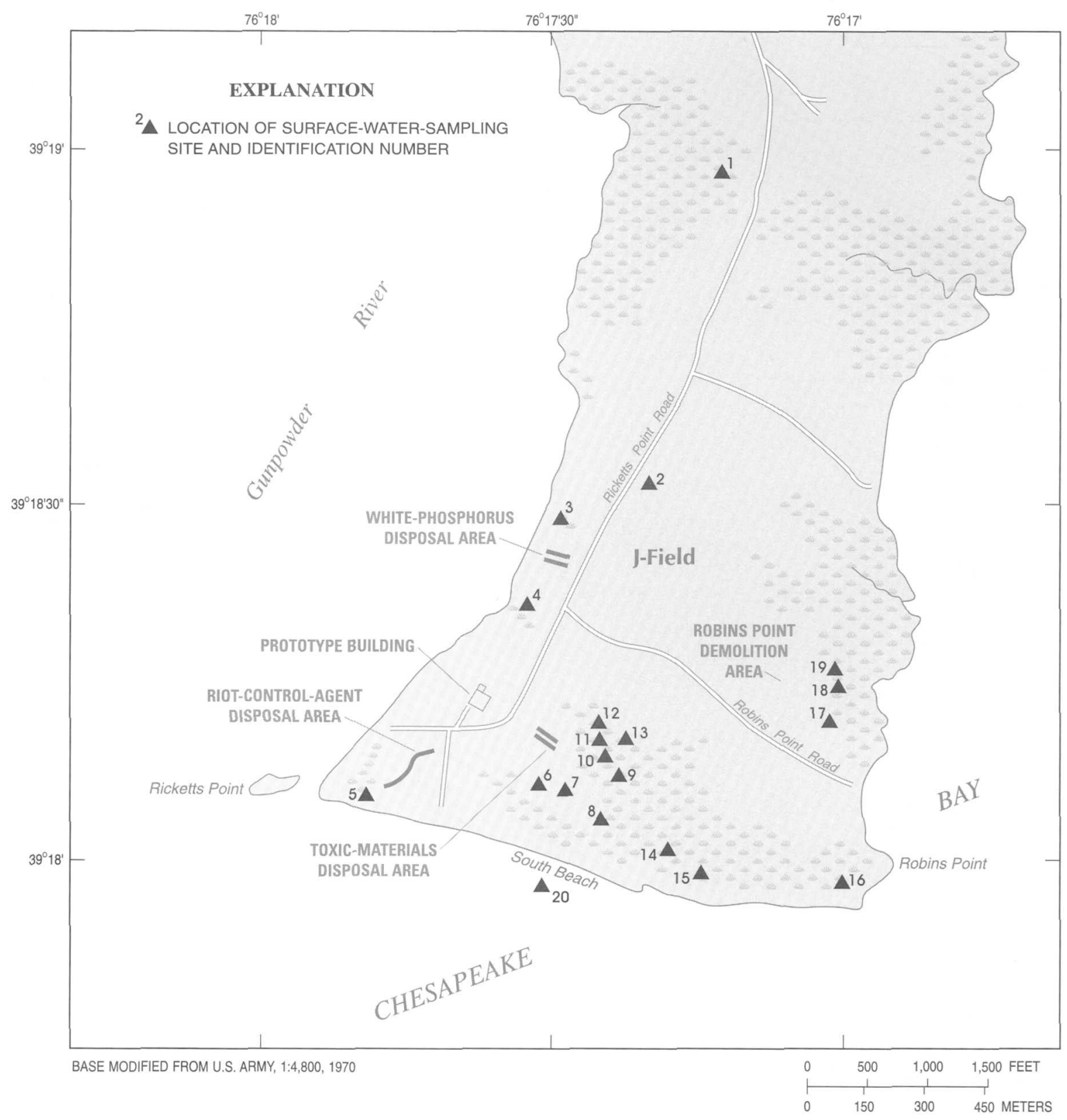

Figure 8. Location of surface-water-sampling sites, April and September 1993, J-Field, Aberdeen Proving Ground, Maryland (from Phelan and others, 1996). 


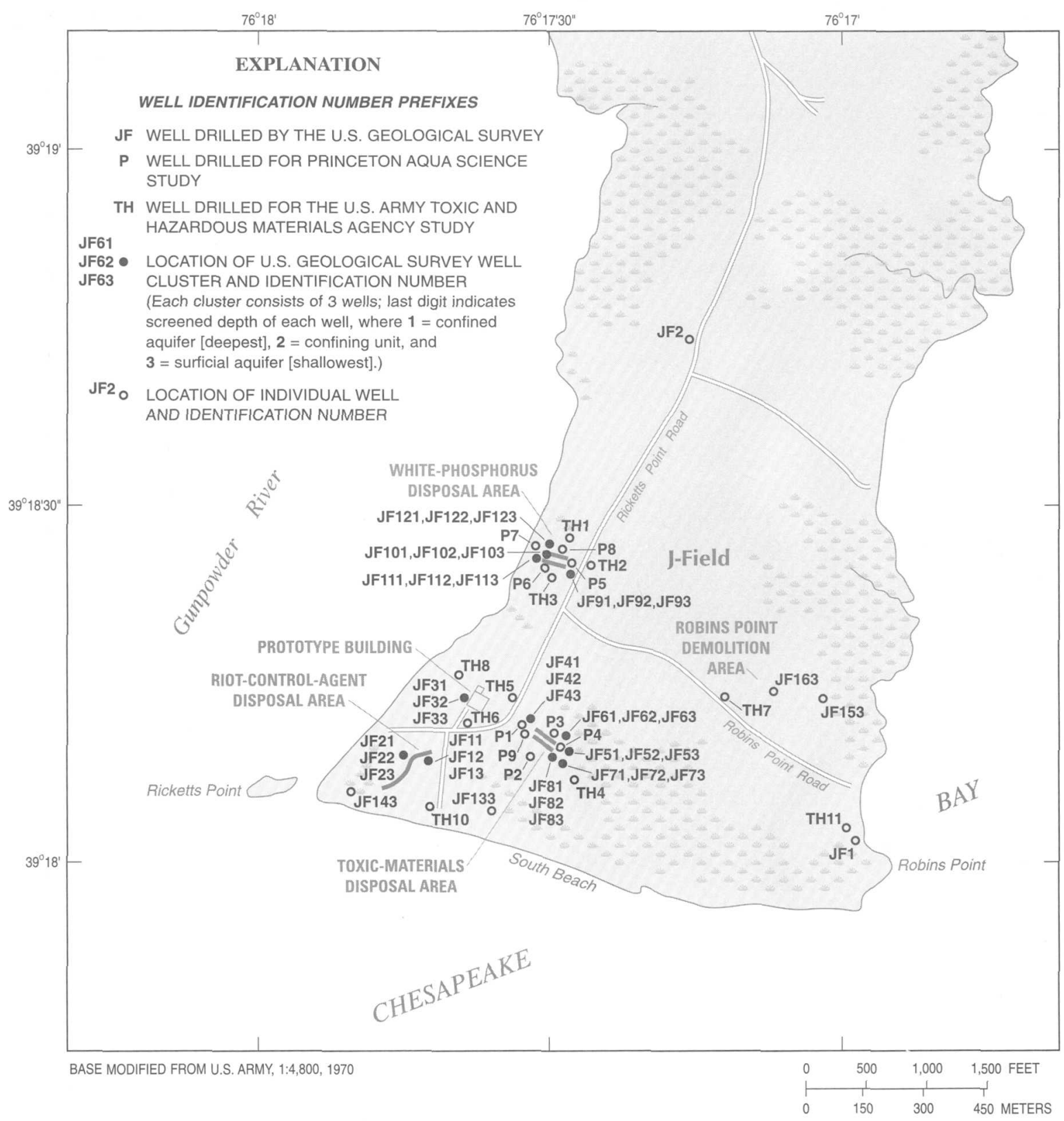

Figure 9. Location of wells at J-Field, Aberdeen Proving Ground, Maryland (modified from Phelan and others, 1996). 
products, cyanide, total organic carbon, total dissolved solids, and total organic halogens.

Borehole Drilling and Well Development

Seven exploratory boreholes were drilled by the USGS to define the subsurface hydrogeologic framework. The boreholes were drilled using a mud-rotary technique to depths of approximately $300 \mathrm{ft}$ below land surface. Five of the boreholes were filled with cement grout after borehole geophysical logging was performed. Wells JF1 and JF2 were screened in the Patapsco Formation (fig. 9). Lithologic logs from the boreholes are presented in Hughes (1993), and the borehole geophysical logs are presented in Phelan and others (1996).

The remaining 40 wells were installed in shallow 10-in.-diameter boreholes that were drilled with a hollow-stem auger rig. All wells were constructed using 4-in. polyvinyl chloride (PVC) well casing. Well screens were made of 4-in. wirewrapped stainless steel. The casing and well screens were threaded to avoid use of glues or solvents in well construction. A filter pack of medium-sized quartz sand was installed using tremie pipe from the bottom of the borehole to $1 \mathrm{ft}$ above the top of the well screen. A 2-ft-thick layer of bentonite clay pellets was added to prevent grout penetration into the filter pack. Cement grout containing 5-percent bentonite was then added through a tremie pipe to fill the annular space between the borehole and casing from the bentonite seal up to land surface. A 6-in. by 6-in. square steel protective pipe was placed around the well casing. A 4-ft by 4-ft cement pad was placed around all finished wells. The wells were developed with an airlift system until either clear water was pumped from the well or, for extremely low-yielding wells, three well volumes of water were removed. Water levels in wells screened in the confining unit were lowered to the screen depth and pumping was stopped to allow the water levels to recover. Development of wells screened in the confining unit may not have been as complete as in the wells with higher yields. The water pumped from the wells during development was sampled for VOC's and then taken to the Edgewood sewage-treatment facility for disposal.
Well-Numbering System

Wells constructed for the Princeton Aqua Science (1984) study are numbered P1 to P9, and the wells constructed for the USATHAMA study are numbered TH1 to TH11 (fig. 9). All of the "P" and "TH" wells are screened in the surficial aquifer. Observation wells JF1 and JF2 were constructed in two exploratory boreholes and are screened in the Patapsco Formation. Well clusters consisting of three observation wells each were constructed at 12 sites and are referred to herein as "USGS well-cluster sites 1 to 12 ." The numbers for the individual wells at the cluster sites begin with the prefix JF, followed by the cluster-site number and a number that indicates the hydrogeologic unit in which each well is screened. The last number is " 1 " for the confined aquifer well, "2" for the confining-unit well, and "3" for the surficial-aquifer well. For example, the confined-aquifer well at USGS well-cluster site 9 is JF91, the confining-unit well is JF92, and the surficial-aquifer well is JF93. Observation wells numbered JF133, JF143, JF153, and JF163 are single, non-clustered wells that are screened in the surficial aquifer. The well-construction data for the observation wells at J-Field are listed in table 1 .

\section{Sampling Methods}

Ground-water samples were collected after wells had been purged of at least three well volumes, and after field parameters had stabilized. Teflon bailers and/or submersible compressed-air piston pumps (stainless steel and Teflon) that did not introduce air into the ground water were used to purge the wells. All purging was done from the top of the water column, and the pump was lowered as the water level dropped.

Water-quality samples during Phase I were collected from the discharge of the low flow (less than $1 \mathrm{gal} / \mathrm{min}$ ) stainless-steel and Teflon sampling pumps. Six gallons of tap water and then 6 gal of distilled water were flushed through the pump and hoses between samples from different wells to prevent cross contamination of the samples. During Phase II, the same purging procedures were used, but samples were collected from clean, dedicated Teflon bailers. All samples were packed in ice and shipped in coolers overnight to the laboratory in Denver, Colorado. All ground-water 
Table 1. Well-construction data for observation wells installed at J-Field, Aberdeen Proving Ground, Maryland

[No., number; ft, feet; ft bls., feet below land surface; MUD, well installed using mud rotary; AUG, well installed using hollowstem auger; K, aquifers in Patapsco Formation; A, confined aquifer; B, confining unit; $C$, surficial aquifer; --, data not available; USATHAMA, U.S. Army Toxic and Hazardous Material Agency]

\begin{tabular}{|c|c|c|c|c|c|c|c|}
\hline $\begin{array}{l}\text { Well } \\
\text { No. }\end{array}$ & $\begin{array}{l}\text { Maryland } \\
\text { permit } \\
\text { No. }\end{array}$ & $\begin{array}{l}\text { Altitude } \\
\text { of land } \\
\text { surface } \\
\text { (ft) }\end{array}$ & $\begin{array}{l}\text { Drilling } \\
\text { method }\end{array}$ & $\begin{array}{l}\text { Depth of } \\
\text { boring } \\
\text { (ft) }\end{array}$ & \multicolumn{2}{|c|}{$\begin{array}{l}\text { Screened } \\
\text { interval } \\
\text { (ft bls) }\end{array}$} & $\begin{array}{l}\text { Unit } \\
\text { screened }\end{array}$ \\
\hline \multicolumn{8}{|c|}{ Wells installed for the U.S. Geological Survey study } \\
\hline JF1 & HA-88-1036 & 4.95 & MUD & 190 & 185 & -190 & $\mathrm{~K}$ \\
\hline $\mathrm{JF} 2$ & HA-88-1035 & -- & MUD & 300 & 208 & -213 & K \\
\hline JF11 & HA-88-1037 & 7.42 & AUG & 90 & 85 & -90 & A \\
\hline $\mathrm{JF} 12$ & HA-88-1038 & 7.30 & AUG & 55 & 50 & -55 & B \\
\hline JF13 & HA-88-1039 & 7.18 & AUG & 25.5 & 20.5 & -25.5 & $\mathrm{C}$ \\
\hline JF21 & HA-88-1040 & 2.99 & AUG & 71 & 68 & -71 & A \\
\hline JF22 & HA-88-1041 & 2.99 & AUG & 52.5 & 47.5 & -52.5 & B \\
\hline JF23 & HA-88-1042 & 3.10 & AUG & 19 & 16 & -19 & $\mathrm{C}$ \\
\hline JF31 & HA-88-1043 & 7.67 & AUG & 81.3 & 73.8 & -78.8 & A \\
\hline JF32 & HA-88-1044 & 7.70 & AUG & 54.4 & 49.4 & -54.4 & B \\
\hline JF33 & HA-88-1045 & 7.79 & AUG & 20 & 15 & -20 & $\mathrm{C}$ \\
\hline JF41 & HA-88-1046 & 10.22 & AUG & 90 & 85 & -90 & A \\
\hline JF42 & HA-88-1047 & 10.30 & AUG & 62 & 57 & -62 & B \\
\hline JF43 & HA-88-1048 & 10.63 & AUG & 35 & 30 & -35 & $\mathrm{C}$ \\
\hline JF51 & HA-88-1050 & 5.02 & AUG & 115 & 110 & -115 & A \\
\hline JF52 & HA-88-1049 & 5.27 & AUG & 65 & 60 & -65 & B \\
\hline JF53 & HA-88-1051 & 5.10 & AUG & 19.2 & 14.2 & -19.2 & $\mathrm{C}$ \\
\hline JF61 & HA- $88-1052$ & 4.29 & AUG & 100 & 95 & -100 & A \\
\hline JF62 & HA- $88-1053$ & 4.08 & AUG & 65 & 60 & -65 & B \\
\hline JF63 & HA-88-1054 & 4.10 & AUG & 19 & 16 & -19 & $\mathrm{C}$ \\
\hline JF71 & HA-88-1055 & 7.26 & AUG & 125 & 120 & -125 & A \\
\hline JF72 & HA-88.1056 & 8.28 & AUG & 81 & 76 & -81 & B \\
\hline JF73 & HA-88-1057 & 7.48 & AUG & 18 & 15 & -18 & $\mathrm{C}$ \\
\hline JF81 & HA-88-1059 & 10.01 & AUG & 123 & 120 & -123 & A \\
\hline JF82 & HA- $88-1058$ & 10.39 & AUG & 75 & 70 & -75 & B \\
\hline JF83 & HA-88-1060 & 10.42 & AUG & 20 & 15 & -20 & $C$ \\
\hline JF91 & HA-88-1061 & 10.18 & AUG & 79 & 74 & -79 & A \\
\hline JF92 & HA-88-1062 & 10.60 & AUG & 55.5 & 50.5 & -55.5 & B \\
\hline JF93 & HA-88-1063 & 10.28 & AUG & 25 & 20 & -25 & $\mathrm{C}$ \\
\hline
\end{tabular}


Table 1. Well-construction data for observation wells installed at J-Field, Aberdeen Proving Ground, Maryland--Continued

\begin{tabular}{|c|c|c|c|c|c|c|c|}
\hline $\begin{array}{l}\text { Well } \\
\text { No. }\end{array}$ & $\begin{array}{l}\text { Maryland } \\
\text { permit } \\
\text { No. }\end{array}$ & $\begin{array}{l}\text { Altitude } \\
\text { of land } \\
\text { surface } \\
\text { (ft) }\end{array}$ & $\begin{array}{l}\text { Drilling } \\
\text { method }\end{array}$ & $\begin{array}{l}\text { Depth of } \\
\text { boring } \\
\text { (ft) }\end{array}$ & \multicolumn{2}{|c|}{$\begin{array}{l}\text { Screened } \\
\text { interval } \\
\text { (ft bls) }\end{array}$} & $\begin{array}{l}\text { Unit } \\
\text { screened }\end{array}$ \\
\hline \multicolumn{8}{|c|}{ Wells installed for the U.S. Geological Survey study--Continued } \\
\hline JF101 & HA-88-1064 & 5.36 & AUG & 76 & 73 & -76 & A \\
\hline JF102 & HA-88-1065 & 5.70 & AUG & 55 & 52 & -55 & B \\
\hline JF103 & HA-88-1066 & 5.41 & AUG & 28 & 25 & -28 & $\mathrm{C}$ \\
\hline JF111 & HA-88-1067 & 6.51 & AUG & 75 & 69.1 & -75 & A \\
\hline JF112 & HA-88-1068 & 6.19 & AUG & 50 & 47 & -50 & B \\
\hline JF113 & HA-88-1069 & 6.77 & AUG & 25 & 22 & -25 & $\mathrm{C}$ \\
\hline JF121 & HA- $88-1070$ & 4.16 & AUG & 70 & 67 & -70 & A \\
\hline JF122 & HA-88-1071 & 4.42 & AUG & 55 & 52 & -55 & B \\
\hline JF123 & HA-88-1072 & 4.15 & AUG & 28 & 25 & -28 & $\mathrm{C}$ \\
\hline JF133 & HA- $88-1423$ & 3.0 & AUG & 10 & 5 & -10 & $\mathrm{C}$ \\
\hline JF143 & HA-88-1415 & 4.9 & AUG & 10 & 5 & -10 & $\mathrm{C}$ \\
\hline JF153 & HA-88-1425 & 5.9 & AUG & 10 & 5 & -10 & C \\
\hline JF163 & HA-88-1422 & 8.7 & AUG & 12 & 5 & -12 & $\mathrm{C}$ \\
\hline \multicolumn{8}{|c|}{ Wells drilled for the Princeton Aqua Science study (Princeton Aqua Science, 1984) } \\
\hline $\mathrm{Pl}$ & HA-81-0529 & 11.61 & AUG & 22 & 5 & -20 & $\mathrm{C}$ \\
\hline $\mathrm{P} 2$ & HA-81-0526 & 8.18 & AUG & 22 & 5 & -20 & $\mathrm{C}$ \\
\hline P3 & HA-81-0527 & 7.76 & AUG & 22 & 5 & -20 & $\mathrm{C}$ \\
\hline P4 & HA- $81-0520$ & 7.19 & AUG & 20 & 5 & -20 & $\mathrm{C}$ \\
\hline P5 & HA-81-0525 & 10.58 & AUG & 17 & 2 & -17 & C \\
\hline P6 & -. & 8.25 & AUG & 22 & 2 & -17 & $\mathrm{C}$ \\
\hline P7 & - & 5.18 & AUG & 20 & 5 & -20 & $\mathrm{C}$ \\
\hline P8 & - & 6.03 & AUG & 20 & 5 & -20 & $\mathrm{C}$ \\
\hline P9 & - & 8.18 & AUG & 22 & 2 & -17 & $\mathrm{C}$ \\
\hline \multicolumn{8}{|c|}{ Wells drilled for the USATHAMA study (Nemeth and others, 1983) } \\
\hline TH1 & - & 4.38 & AUG & -- & 6 & -16 & $\mathrm{C}$ \\
\hline TH2 & -- & 10.45 & AUG & -- & 8 & -18 & $\mathrm{C}$ \\
\hline TH3 & -- & 6.86 & AUG & -- & 8 & -18 & $\mathrm{C}$ \\
\hline TH4 & -- & 5.26 & AUG & -- & 8 & -18 & $\mathrm{C}$ \\
\hline TH5 & -. & 9.24 & AUG & -- & 10 & -20 & $\mathrm{C}$ \\
\hline TH6 & -- & 9.64 & AUG & -. & 10 & -20 & $\mathrm{C}$ \\
\hline TH7 & -- & 5.61 & AUG & -- & 7 & -17 & $C$ \\
\hline TH8 & -. & 6.19 & AUG & -- & 7 & -17 & C \\
\hline TH10 & -- & 6.92 & AUG & -- & 8 & -18 & $\mathrm{C}$ \\
\hline TH11 & - & 5.28 & AUG & -- & 8 & -18 & $\mathrm{C}$ \\
\hline
\end{tabular}


samples to be analyzed for dissolved inorganic constituents were filtered through a 0.45 -micron filter.

After each well had been purged and sampled, dissolved oxygen was measured within the well, using a meter with a 50 -ft-long probe cable. A stirrer was attached to the probe to allow proper water flow past the membrane at the bottom of the probe. In the surficial aquifer wells, dissolved oxygen was measured at the well screen.

Dissolved oxygen concentrations in wells screened deeper than $50 \mathrm{ft}$ could not be measured at the well screen, but was measured as deep in the well as possible.

\section{Laboratory Analysis}

The ground-water samples from Phase I were analyzed by Data Chem Laboratories in Salt Lake City, Utah, and the soil samples were analyzed by Arthur D. Little Environmental Chemistry Laboratory in Cambridge, Massachusetts. The Phase I ground-water and soil-quality sampling was done in accordance with EPA-approved SW846 methods used for samples associated with SWMU's.

During the Phase I sampling, ground-water and soil samples were analyzed for organic compounds, which included VOC's and SVOC's, explosives, insecticides, and organosulfur compounds, in addition to inorganic constituents such as major ions and trace metals. Phase II groundwater and surface-water samples from 1993 were analyzed by Rocky Mountain Analytical Laboratories in Denver, Colorado, using U.S. Environmental Protection Agency-approved Contract Laboratory Program (CLP) methods for CERCLA sites. The Phase II ground-water and surface-water samples were analyzed for similar constituents and properties as the Phase I samples.

\section{Quality Assurance and Data Evaluation}

Assessment of the quality of the soil, surfacewater, and ground-water data is an important step in data interpretation. A summary of this assessment is provided below and a more detailed discussion is provided in Phelan and others (1996).

\section{Soils Data}

On the basis of relative percent differences (RPD's) between duplicate analyses, measurement reproducibility for inorganic analytes in soils is within reason given the sample media. There were few detections of VOC and SVOC analytes in soils. The only organic analyte detected in duplicate sample pairs was acetone, which was found at low levels in three of the four pairs of duplicate samples (Phelan and others, 1996). Acetone is not representative of field samples, is probably a laboratory contaminant, and, therefore, is not included in the interpretation of soil data in this report. No RPD's could be calculated for organic compounds in soils because of the lack of meaningful detectable concentrations in duplicate samples. Analyses of soil samples collected from sites immediately after the most contaminated sites indicated that no cross contamination occurred between consecutive samples. On the basis of the above discussion, the overall quality of the soil data is considered good.

\section{Surface-Water Data}

Reproducibility was good for most major ions, with RPD's ranging from 0 to 10 percent. The highest variability in the data for one duplicate pair was for total iron, with an RPD of 42 percent. Reproducibility for trace metals was acceptable, with RPD's less than 29 percent. The reproducibility of surface-water organic data was generally good, and data were unbiased for concentrations reported as "less than $10 \mu \mathrm{g} / \mathrm{L}$ " (Phelan and others, 1996). Estimates of measurement reproducibility for the surface-water VOC and SVOC data are limited, however, because the duplicate sample pairs seldom contained measurable concentrations of VOC's and SVOC's. Quality-assurance blank data indicated that laboratory contamination of surface-water samples probably resulted for four VOC's--acetone, methylene chloride, methyl isobutyl ketone, and methyl ethyl ketone, and one SVOC-- $N$-nitrosodi-phenylamine (Phelan and others, 1996). These five analytes were detected at concentrations less than $10 \mu \mathrm{g} / \mathrm{L}$ in at least one trip blank, one ambient blank, and several laboratory blanks. The laboratory reported that acetone and methylene chloride are common laboratory contaminants in the methods used for these analyses. Data on these five analytes are, therefore, not interpreted in this report and are not reported in tables; however, the data are presented in Phelan and others (1996). 


\section{Ground-Water Data}

Phase I and II ground-water samples were collected with different equipment and during different years. Samples for Phase I and II were analyzed by different laboratories. Changes in field and laboratory procedures were due to changes in regulatory requirements.

The reproducibility of Phase I and II inorganic ground-water-quality data is good on the basis of median relative percent differences of generally less than 10 percent between duplicate samples; however, during Phase I, some field blanks showed evidence of possible carry over of inorganic analytes at low levels. With the exception of perhaps phosphorus, sample concentrations for these analytes were often at least an order of magnitude higher than the concentrations found in the field blanks (Phelan and others, 1996).

During Phase II sampling, concentrations of total calcium, magnesium, sodium, iron, manganese, and zinc were detected in at least two of the three field blanks. The concentrations of calcium, magnesium, and iron in field blanks were lower than those in ground-water samples.

Manganese and zinc concentrations in field blanks, however, sometimes exceeded those in the groundwater samples. Suspect data are qualified in the data tables in this report with a " $v$ ".

The overall reproducibility of Phase I and II organic ground-water-quality data is good; however, there are cases of possible sample bias. An analysis of trip, field, and laboratory blank data from Phase II indicates that at least 50 percent of the blanks were contaminated with one or more of the following eight analytes:

$\begin{array}{ll}\text { Acetone } & \text { Methylene chloride } \\ \text { Methyl ethyl ketone } & \text { Methyl isobutyl ketone } \\ \text { Methyl } n \text {-butyl ketone } & \begin{array}{l}\text { bis (2-ethyl-hexyl) } \\ \text { phthalate }\end{array} \\ \text { Di-n-octyl phthalate } & N \text {-nitrosodipheny- } \\ & \text { lamine. }\end{array}$

Concentrations of these analytes in blanks seldom exceeded 10 to $20 \mu \mathrm{g} / \mathrm{L}$. Because contamination was frequent, however, Phase II concentration data for these eight analytes have been qualified with a " $v$ " in the data tables.

\section{Assessment of Soil, Surface-Water, and Ground-Water Contamination at Selected J-Field Sites}

Soil, surface-water, and ground-water contamination were assessed at the toxic-materials disposal area, the white-phosphorus disposal area, the riot-control-agent disposal area, the Robins Point demolition area, and the prototype building. Relatively uncontaminated sites were selected as control sites to provide a basis for comparison with contaminated sites or sites that were suspected to be contaminated.

\section{Selection and Assessment of Control Sites Soils}

It is not possible to compare contaminated soils to uncontaminated soils at J-Field because detectable levels of trace metals and certain organic analytes are prevalent, which may be partially due to atmospheric deposition of combustion products. Because there are no control sites for soils at $\mathrm{J}$-Field, concentrations of metals in soils at contaminated sites were compared to average crustal abundances or to ranges typically found in natural soils. With the exception of benzoic acid, which is a naturally occurring organic compound that was found in nearly all soil samples at J-Field, the VOC's and SVOC's detected in soils are considered contaminants of anthropogenic origin. Concentrations of trace metals in sediment from borehole samples described by Hughes (1993) and soil samples from Phelan and others (1996) were compared to average crustal abundances to assess the level of contamination. Enrichment factors give an indication of how a concentration of an analyte in soils compares to concentrations that could be expected due to natural occurrences. Enrichment factors greater than 10 suggest possible contamination; however, conclusions based on these comparisons should be made cautiously because crustal abundances are based on broad averages of natural materials. The greater the enrichment factor, the greater the probability that contamination is present. The enrichment factors have been normalized to iron to correct for grainsize effects on the concentrations and are calculated with the formula below. The median concentration of all iron samples from each site 
was used to calculate the enrichment factors for that specific site.

$$
\text { Enrichment factor }=\frac{C_{m} / P_{f e}}{A C_{m} / A C_{f e}},
$$

where

$C_{m}$ is the concentration of the metal, in micrograms per gram,

$P_{f e}$ is the median percent of iron in the soil samples at each site at J-Field,

$A C_{m}$ is the average crustal abundance for the metal, in micrograms per gram, and

$A C_{f e}$ is the average crustal abundance for iron, in percent [average crustal abundances from Greenwood and Earnshaw (1986)].

\section{Surface Water}

Because most surface-water runoff at J-Field originates at or near known contaminated areas, and because past burning and current demolition activities provide a potential source of atmospheric contaminants, no surface-water bodies were considered to be representative of background conditions. The surface water at site JFSW20, which is in the Chesapeake Bay and was sampled during the spring and fall of 1993, was relatively uncontaminated and can be used as a basis of comparison for the runoff from the SWMU's and from the tidal and nontidal marshes and ponds at J-Field. No organic contamination was detected at site JFSW20. Concentrations of inorganic and organic constituents in surface water at J-Field that exceeded concentrations at JFSW20 could indicate possible contamination. Surface-water samples from J-Field also were compared to surface-water samples that were collected at Carroll Island (Tenbus and Phillips, 1996), part of Aberdeen Proving Ground that is west of J-Field, across the Gunpowder River (fig. 1).

\section{Ground Water}

Control wells were selected from the group of wells that were sampled during Phase I and/or Phase II at J-Field, to be used as a basis of comparison for evaluating which wells were contaminated. The following criteria were established for ground-water-control wells and had to be met in both Phase I and Phase II if the well was sampled during both sampling rounds: (1) the $\mathrm{pH}$ was below 8.0, (2) the concentration of any organic compound was $5 \mu \mathrm{g} / \mathrm{L}$ or less, (3) two or fewer organic compounds were detected in either Phase I or Phase II, (4) no trace metals except iron or manganese exceeded an MCL (or SMCL), and (5) the well was not screened in the surficial aquifer immediately downgradient of a known contaminated site. Although ground-water samples from wells JF1 and JF2 met these criteria, they were not considered control wells because they are screened in the Patapsco Formation, which is below the confined aquifer of the Talbot Formation. Wells that are considered control wells are listed in table 2.

Table 2. Ground-water-control wells at J-Field, Aberdeen Proving Ground, Maryland

$\left[*\right.$, sampled only during Phase $1 ;{ }^{* *}$, sampled only during Phase II]

\begin{tabular}{ccc}
\hline $\begin{array}{c}\text { Surficial-aquifer } \\
\text { wells }\end{array}$ & $\begin{array}{c}\text { Confining-unit } \\
\text { wells }\end{array}$ & $\begin{array}{c}\text { Confined-aquifer } \\
\text { wells }\end{array}$ \\
\hline P5* & JF12 & JF11 \\
TH3 & JF32 & JF101 \\
TH6* & JF42* & JF111 \\
TH10 & JF92* & JF121 \\
TH11* & & \\
JF43 & & \\
JF93 & & \\
JF163** & & \\
\hline
\end{tabular}

Field Parameters

Summary statistics for field parameters in Phase I ground-water samples from control wells in the surficial aquifer, confining unit, and confined aquifer are shown in table 3 . These statistics 


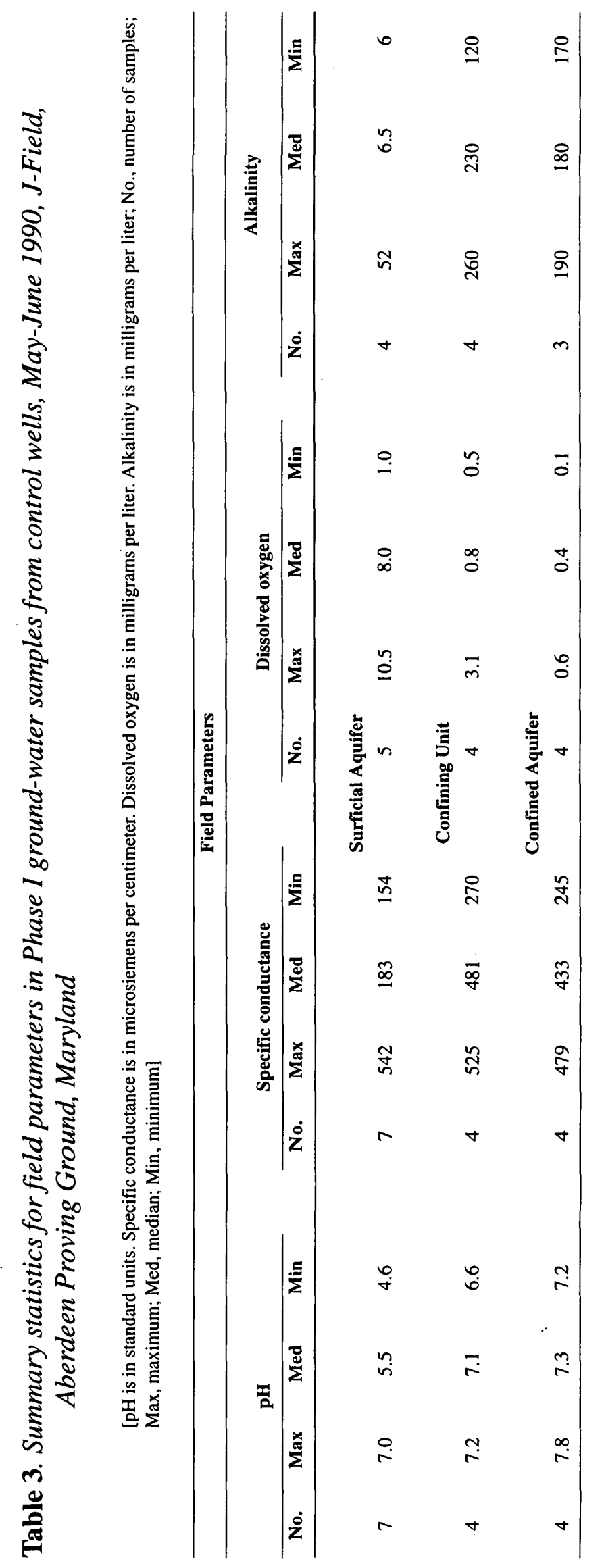


provide a basis for comparing field parameters in control wells to those in contaminated wells. Only Phase I data are presented here because more control wells were sampled during Phase I than during Phase II, and the inclusion of Phase II data in the statistics would bias the data in favor of wells that were sampled twice. Median values for alkalinity and specific conductance were highest in the confining unit, slightly lower in the confined aquifer, and lowest in the surficial aquifer. The median $\mathrm{pH}$ values were higher in the confining unit and confined aquifer compared to the surficial aquifer, probably due to the acidity of precipitation that recharges the surficial aquifer. Dissolved oxygen concentrations were lower in the confining unit and confined aquifer than in the surficial aquifer.

\section{Inorganic Constituents}

Major-ion concentrations were used to provide a basis to compare control wells with contaminated wells and to determine where ground water was susceptible to brackish-water intrusion. Ground water from control wells in the surficial aquifer (table 2) had the lowest total concentrations of major ions. Concentrations of sodium, potassium, chloride, and fluoride in control wells in the surficial aquifer were similar to those in control wells in the confining unit and confined aquifer. Concentrations of calcium and bicarbonate were similar in ground water from control wells in the confining unit and the confined aquifer and these concentrations were higher than in control wells in the surficial aquifer. Sulfate concentrations were lower in ground water from control wells in the confining unit and confined aquifer than in ground water from control wells in the surficial aquifer. Iron and manganese were detected at levels above their respective SMCL's (300 and $50 \mu \mathrm{g} / \mathrm{L}$ ) during Phases I and II at nearly all wells and in the surficial aquifer, the confining unit, and the confined aquifer.

Eighteen trace metals were analyzed during Phase I, and seven were analyzed during Phase II. Dissolved trace metals detected in samples from ground-water control wells during Phase I sampling include aluminum, arsenic, barium, cobalt, and zinc. Barium, cobalt, and zinc were detected in Phase II. Summary statistics for dissolved trace metals in Phase I and II ground-water samples from control wells are shown in table 4.

Arsenic, which has a detection limit of $2 \mu \mathrm{g} / \mathrm{L}$, was present in control wells in the Phase I samples in the confined aquifer at concentrations below $5 \mu \mathrm{g} / \mathrm{L}$ and was below the detection limit in control wells in the surficial aquifer and confining unit. In the samples from Phase I, barium concentrations were similar in control wells in the surficial and confined aquifers. In the Phase II samples, cobalt was present in some control wells in the surficial aquifer, but not in control wells in the confining unit or the confined aquifer. In both the Phase I and Phase II samples, zinc concentrations were higher in control wells in the surficial aquifer than in control wells in the confining unit or confined aquifer.

\section{Organic Compounds}

The VOC's and SVOC's of interest are almost always of anthropogenic origin (with the exception of benzoic acid), and any detection can be considered to be evidence of contamination. Organic compounds detected in Phase I in samples from the ground-water control wells included a concentration of $3.5 \mu \mathrm{g} / \mathrm{L}$ of benzene detected in well JF12 (confining unit), and a concentration of $2.2 \mu \mathrm{g} / \mathrm{L}$ of chloroform in well JF42 (confining unit). In Phase II ground-water samples from control wells screened in the surficial aquifer, chloroethane was detected at a concentration of $4.0 \mu \mathrm{g} / \mathrm{L}$ in well JF12 and cyclotetramethylene tetranitramine (HMX, an explosive) was detected at a concentration of $2.6 \mu \mathrm{g} / \mathrm{L}$ in well JF43.

\section{Assessment of the Toxic-Materials Disposal Area}

The toxic-materials disposal area is the most contaminated site at J-Field. Ground-water discharge and surface-water runoff in the vicinity discharge to the nontidal marsh to the east and south of the disposal area (Hughes, 1993) (fig. 5). Soil contamination to the east of the disposal pits probably resulted from runoff from the pits. On the basis of soil-gas measurements, two plumes of organic contamination were mapped downgradient of the disposal pits (Hughes, 1993). Organic parent and degradation compounds were detected in surface water and ground water downgradient of the disposal pits. 


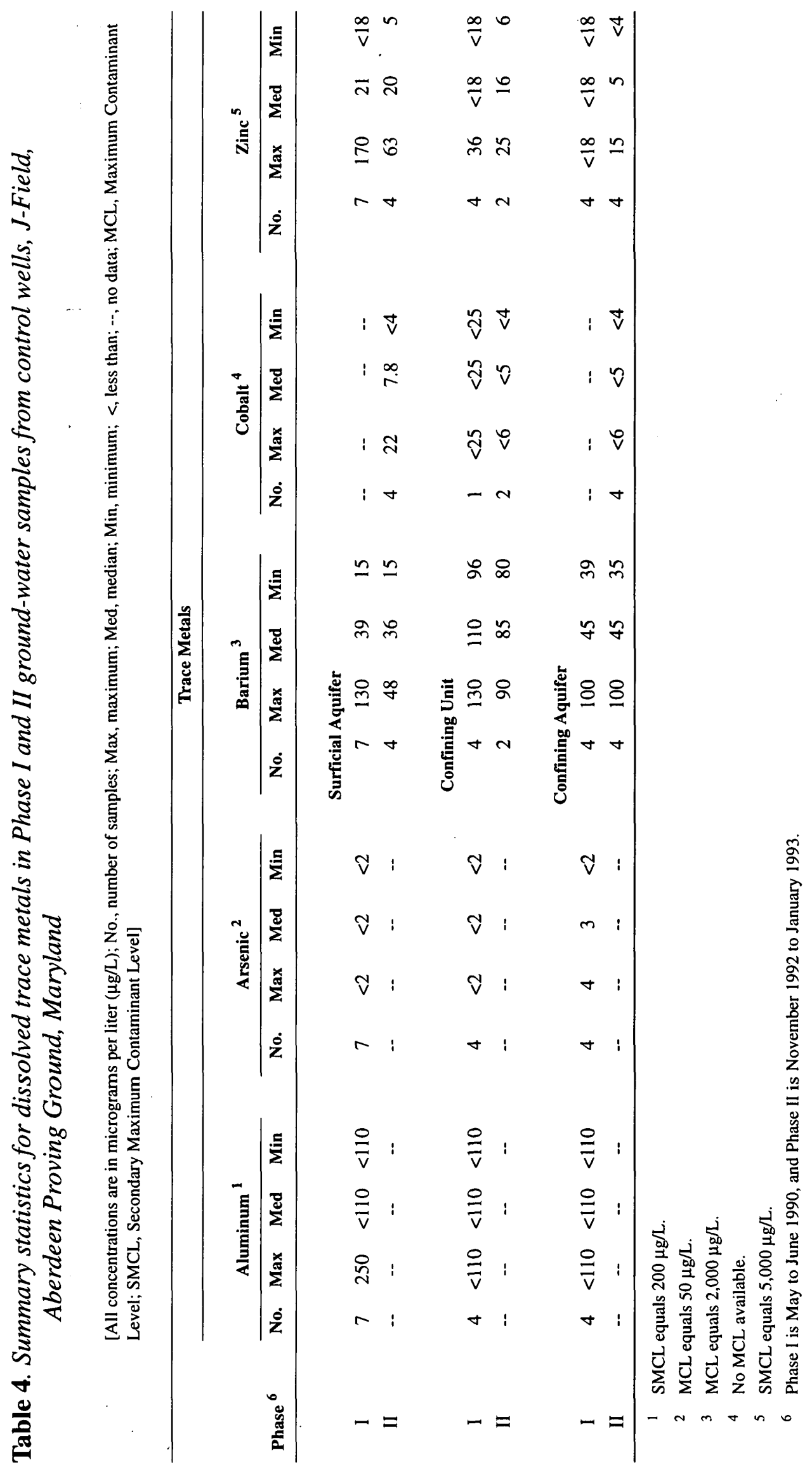


The locations of soil-sampling sites in the toxic-materials disposal area are shown in figure 7 , surface-water-sampling sites are shown in figure 8 , and well locations are shown in figure 9 . The only ground-water control wells at the toxic-materials disposal area are JF43, which is screened in the surficial aquifer, and JF42, which is screened in the confining unit. Both of these control wells are near Ricketts Point Road, uphill (west) and upgradient of the disposal pits.

\section{Soil Gas}

On the basis of soil-gas measurements, two plumes of organic contamination were mapped downgradient of the disposal pits at the toxicmaterials disposal area by Hughes (1993). The orientations of these plumes generally followed the ground-water-flow paths from the disposal pits. One plume extended toward the east; and the other extended toward the south, each toward a different arm of the nontidal marsh. The general directions of ground-water flow in the surficial aquifer in the toxic-materials disposal area are shown in figures 5 and 10.

The first set of soil-gas samples were collected closer to the disposal pits and observation wells, and with a tighter grid pattern than the second set of soil-gas samples. The extent of the contamination plumes based on Phase I soil-gas data for trichloroethene (TCE), tetrachloroethene (PCE), and alkanes [tetrachloroethane (PCA), carbon tetrachloride, and chloroform] as defined by Hughes (1993) is shown in figure 10. Maps of soil-gas data for the Phase II soil-gas samples are presented in Hughes (1993).

\section{Soils}

Chromium, copper, and lead were detected in all soil samples from the area surrounding the disposal pits (table 5). Concentrations of the trace metals arsenic, antimony, cadmium, copper, chromium, lead, and mercury in soils near the disposal pits were well in excess of concentrations typically found in the Talbot Formation, suggesting a local source of contamination. The distribution and concentration of trace metals are shown in figure 11. The area where debris from past burning activities has been pushed out to the edge of the marsh east of the disposal pits (push-out area) had the highest concentrations of metals. The metal and organic contamination in this area also may have resulted from runoff from the disposal pits.

The enrichment factors for metals detected in soils at the toxic-materials disposal area are shown in table 6. On the basis of enrichment factors, median arsenic concentrations in soil samples at the toxic-materials disposal area were slightly elevated when compared to the average crustal abundances, and median concentrations of lead showed a significant level of contamination. The enrichment factors of the maximum concentrations of metals in soils showed high levels of contamination for arsenic, antimony, boron, copper, and lead. At site JF29 (fig. 7), the maximum concentration of mercury detected was greater than $0.5 \mu \mathrm{g} / \mathrm{g}$, which was above the calibration range of the instrument. Mercury contamination is indicated at this site because this concentration represents an enrichment factor of greater than $\mathbf{3 0}$ times the average crustal abundance.

Organic compounds detected in soils at J-Field are shown in table 7. The locations and concentrations of organic compounds detected in soils near the toxic-materials disposal area are shown in figure 11. TCE was the only VOC detected in soils and was present at concentrations of 0.01 to $0.02 \mu \mathrm{g} / \mathrm{g}$ (fig. 11). Other VOC's in the soils near land surface (where the samples were collected) have probably volatilized over time. The actual distribution of VOC's in the soils does not reflect the distribution anticipated on the basis of the soilgas measurements. There were no detections of SVOC's at the soil-sampling sites in the southeast soil-gas plume. There were five detections of SVOC's at sites in the soil-gas plume east of the disposal pits. Benzo-(a)anthracene, benzylbutyl phthalate, di-n-butyl phthalate, bis-2-ethylhexyl phthalate, and hexachlorobenzene were detected at concentrations well above the detection limit. Detection limits ranged from 0.26 to $2.0 \mu \mathrm{g} / \mathrm{g}$ depending on the compound and the date of analysis (table 7). 
TCE CONCENTRATIONS IN GROUND WATER,

IN MICROGRAMS PER LITER (PHASE I / PHASE II)

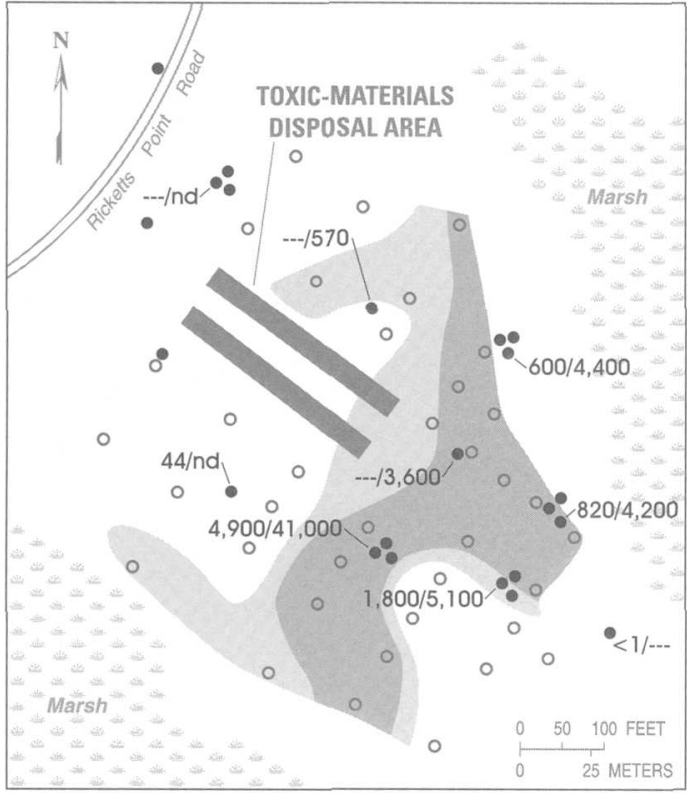

SOIL-GAS CONCENTRATIONS,

TCE RELATIVE-FLUX VALUES (lon counts)

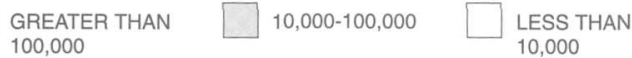
100,000 10,000
PCE CONCENTRATIONS IN GROUND WATER,

IN MICROGRAMS PER LITER (PHASE I / PHASE II)

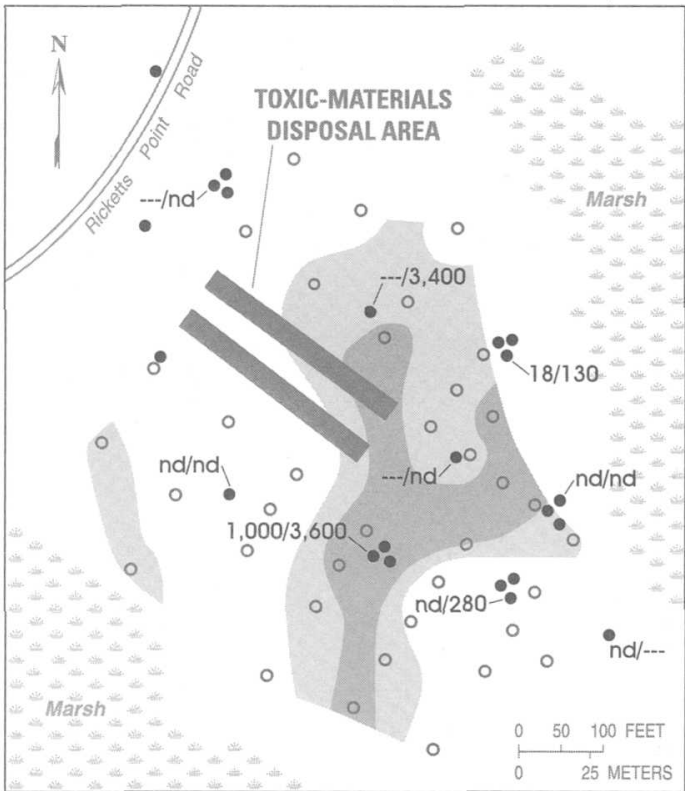

SOIL-GAS CONCENTRATIONS,

PCE RELATIVE-FLUX VALUES

(lon counts)

GREATER THAN

100,000

$10,000-100,000$

LESS THAN 10,000

GENERAL DIRECTIONS OF GROUND-WATER FLOW IN THE SURFICIAL AQUIFER

CTET, AND CHLOROFORM IN GROUND WATER,

IN MICROGRAMS PER LITER (PHASE I / PHASE II)
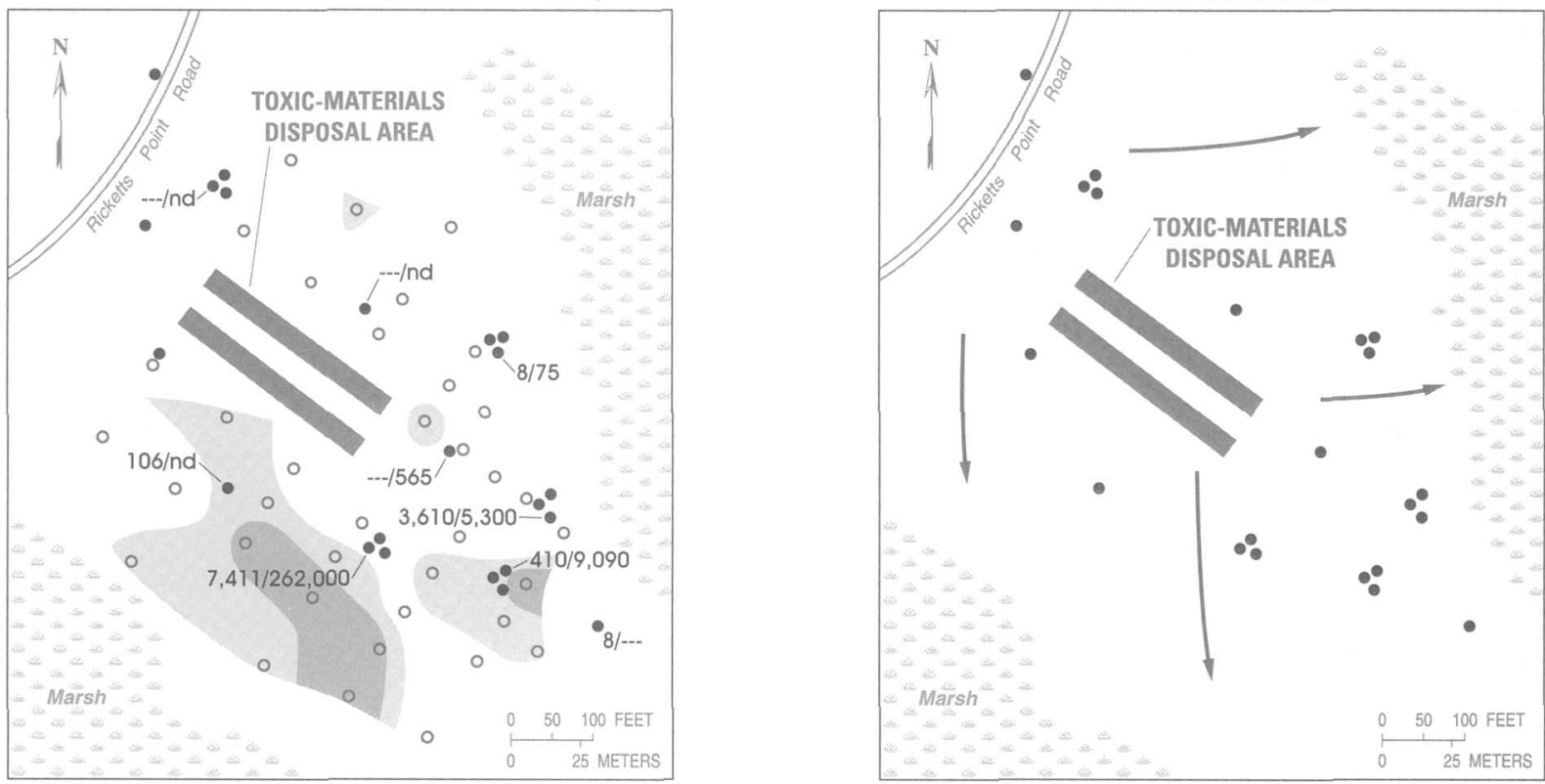

SOIL-GAS CONCENTRATIONS,

ALKANE RELATIVE-FLUX VALUES

$$
\text { (lon counts) }
$$

GREATER THAN $\square 25,000-100,000 \square$ LESS THAN

\section{EXPLANATION}

18/130. WELL LOCATION (Numbers are concentrations,
in micrograms per liter, for Phase I / Phase II.)

\section{- SOIL-GAS COLLECTOR LOCATION}

GENERAL DIRECTION OF GROUND-WATER FLOW IN THE SURFICIAL AQUIFER

[TCE, trichloroethene; PCE, tetrachloroethene; PCA, tetrachloroethane; TCA, trichloroethane; CTET, carbon tetrachloride; nd, not detected; ---, not analyzed; <, less than]

Figure 10. Results of Phase I soil-gas analyses compared to organic compounds detected in the surficial aquifer during Phase I and II ground-water sampling, and directions of ground-water flow in the surficial aquifer at the toxic-materials disposal area, J-Field, Aberdeen Proving Ground, Maryland (modified from Hughes, 1993). 


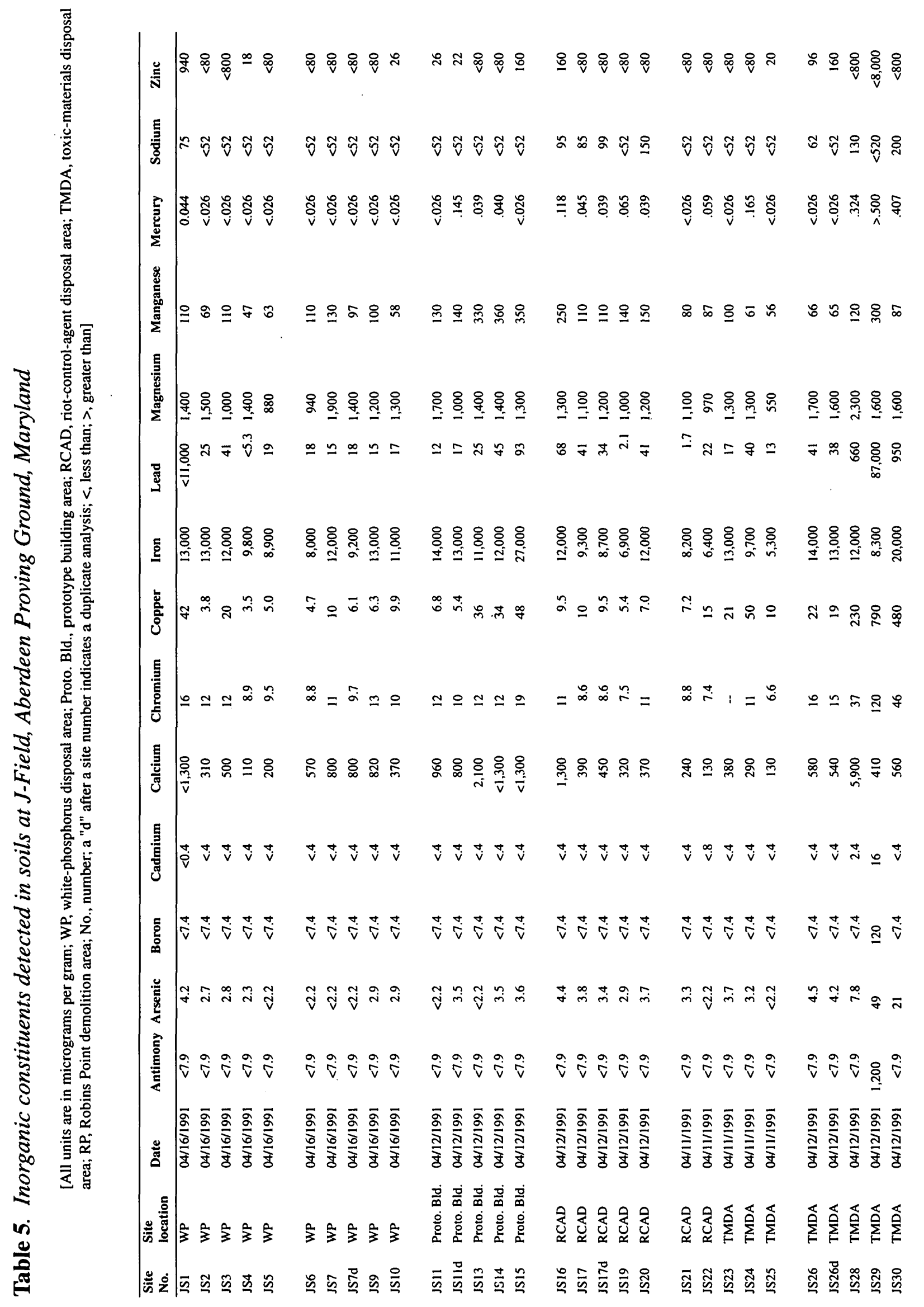




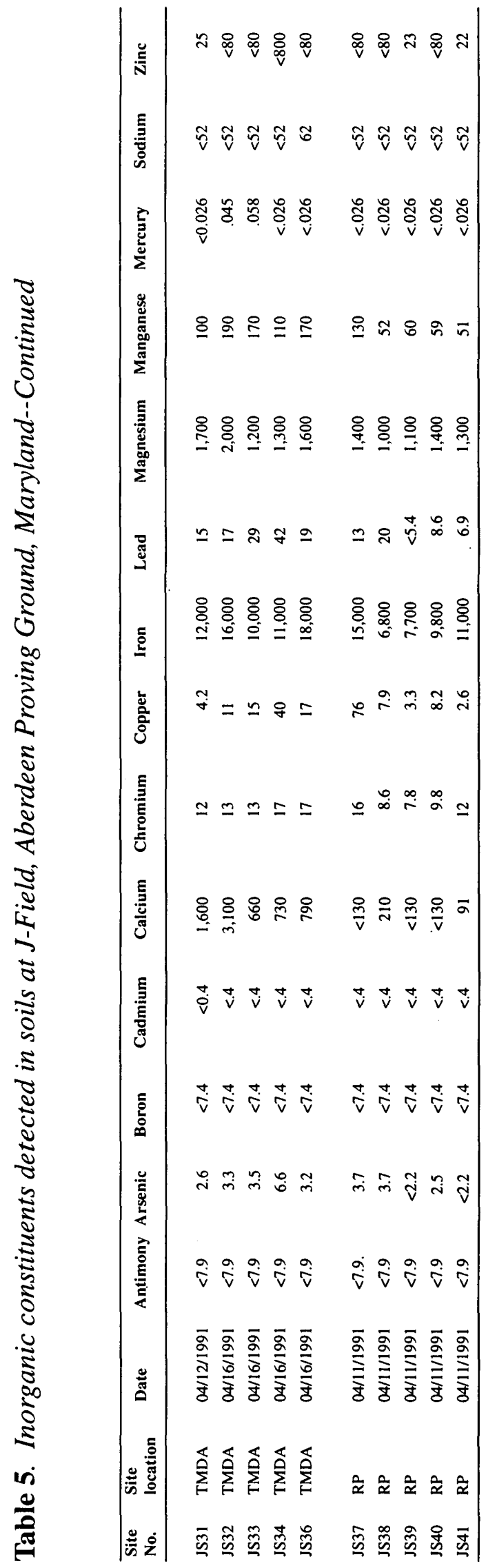




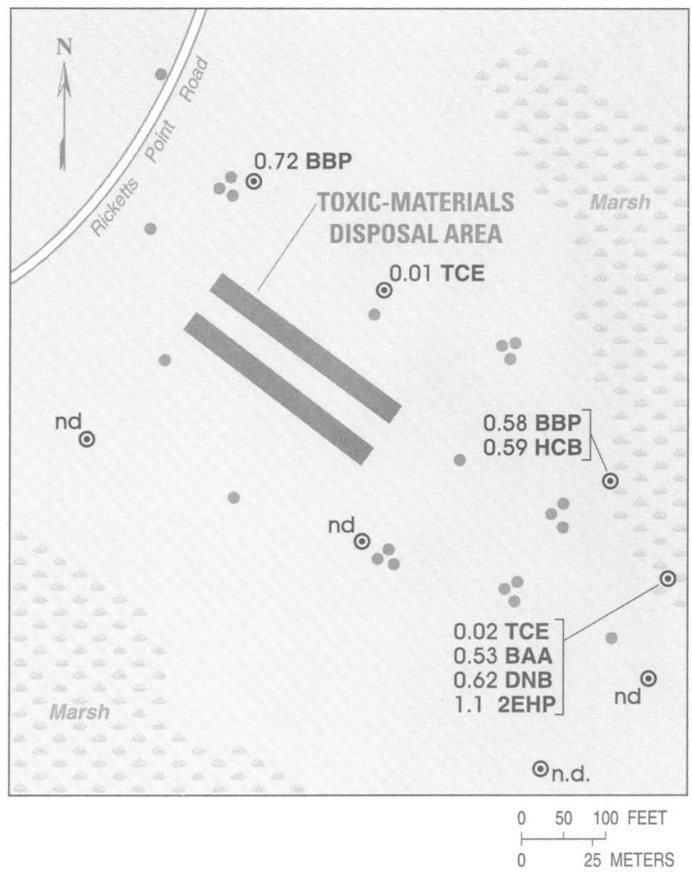

TRACE METALS IN SOILS, IN MICROGRAMS PER GRAM

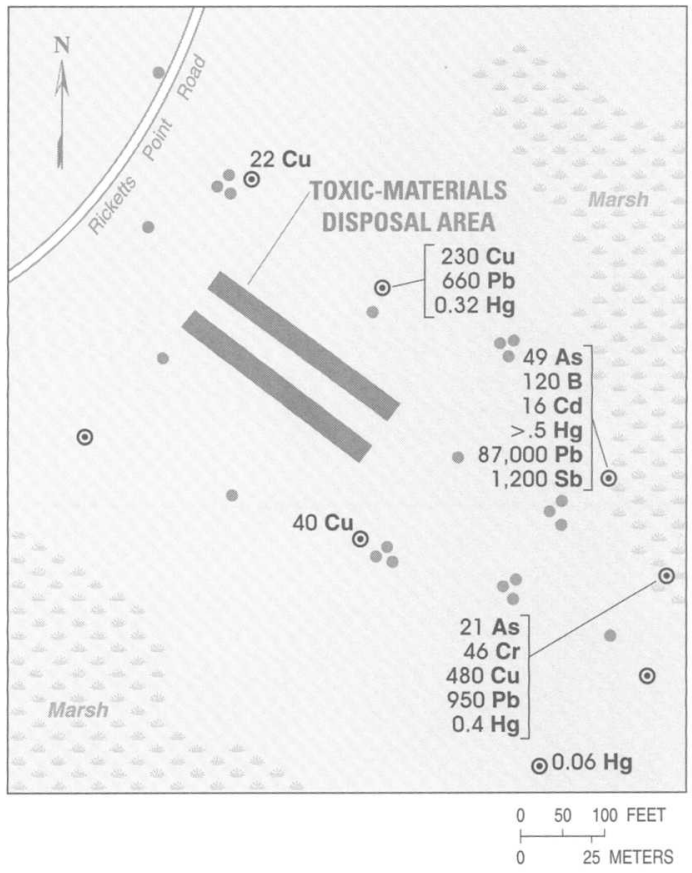

\section{EXPLANATION}

\section{- WELL LOCATION \\ ○ SOIL-QUALITY SAMPLING SITE}

[TCE, trichloroethene; BBP, benzylbutyl phthalate; HCB, hexachlorobenzene; BAA, benzo-(a)-anthracene; DNB, di-n-butyl-phthalate; 2EHP, bis 2-ethylhexylphthalate As, arsenic; B, boron; Cd, cadmium; $\mathbf{C r}$, chromium; $\mathbf{C u}$, copper; $\mathbf{H g}$, mercury; $\mathbf{P b}$, lead; $\mathbf{S b}$, antimony; nd, not detected; $\mu \mathrm{g} / \mathrm{g}$, micrograms per gram; >, greater than]

(NOTE concerning trace metals map: $\mathbf{A s}, \mathrm{Cr}, \mathrm{Cu}$, and $\mathrm{Pb}$ were detected at all sites in the area shown. If the concentrations for these four trace metals are not specified for each site on the map, the concentrations were less than the following: As, $10 \mu \mathrm{g} / \mathrm{g} ; \mathbf{C r}, 20 \mu \mathrm{g} / \mathrm{g} ; \mathbf{C u}, 20 \mu \mathrm{g} / \mathrm{g} ; \mathrm{and} \mathbf{P b}, 50 \mu \mathrm{g} / \mathrm{g}$.)

Figure 11. Organic compounds and trace metals detected in soils at the toxic-materials disposal area, J-Field, Aberdeen Proving Ground, Maryland. 


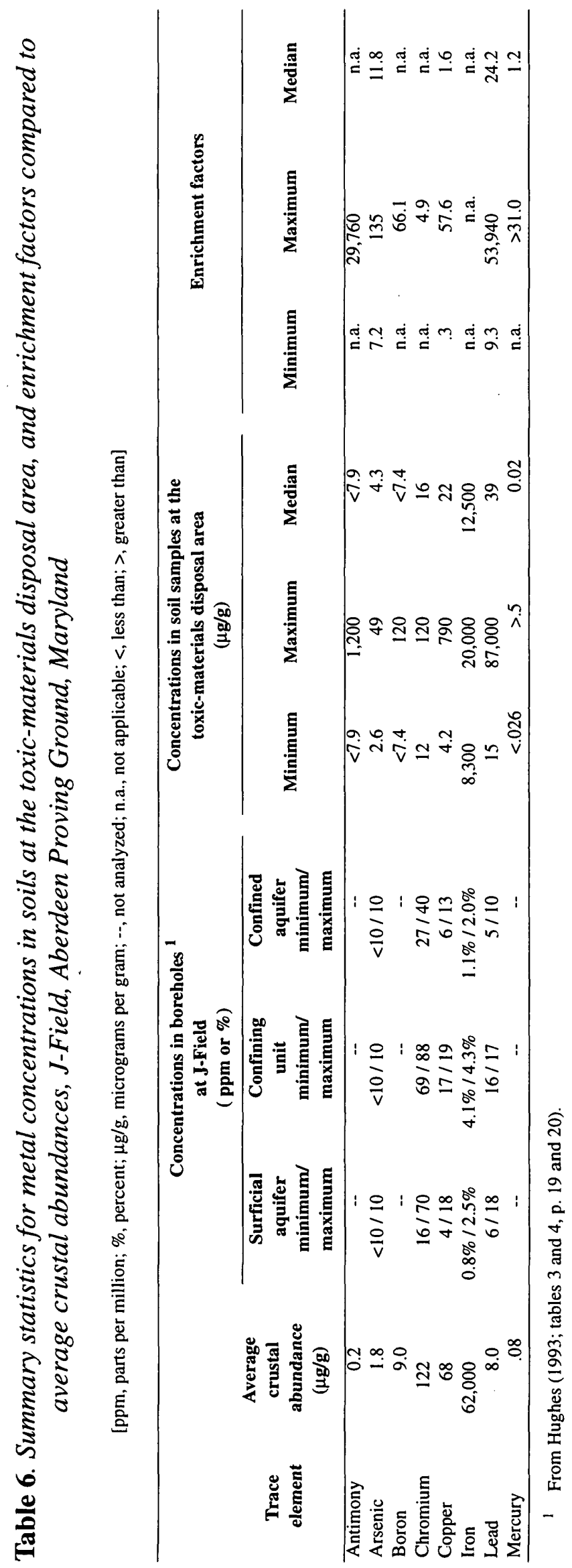


Table 7. Organic compounds detected in soils at J-Field, Aberdeen Proving Ground, Maryland

[All units are in micrograms per gram; detected concentrations are shown in bold numbers; a "d" after a site number indicates a duplicate analysis; No., number; <, less than; --, data not available

Site locations:

WP, white-phosphorus disposal area

Proto. Bld., prototype building area

RCAD, riot-control-agent disposal area

TMDA, toxic-materials disposal area

RP, Robins Point demolition area]

\begin{tabular}{|c|c|c|c|c|c|c|c|c|c|}
\hline \multirow[b]{2}{*}{$\begin{array}{l}\text { Site } \\
\text { No. }\end{array}$} & \multirow[b]{2}{*}{$\begin{array}{l}\text { Site } \\
\text { location }\end{array}$} & \multirow[b]{2}{*}{ Date } & \multicolumn{2}{|c|}{$\begin{array}{l}\text { Volatile organic } \\
\text { compounds }\end{array}$} & \multicolumn{5}{|c|}{ Semivolatile organic compounds } \\
\hline & & & $\begin{array}{l}\text { 1,1,1- } \\
\text { TCA }\end{array}$ & TCE & $\begin{array}{l}\text { Benzo-(a) } \\
\text { anthracene }\end{array}$ & $\begin{array}{l}\text { Benzyl- } \\
\text { butyl } \\
\text { phthalate }\end{array}$ & $\begin{array}{l}\text { Di-n- } \\
\text { butyl } \\
\text { phthalate }\end{array}$ & $\begin{array}{l}\text { bis-2- } \\
\text { Ethylhexyl } \\
\text { phthalate }\end{array}$ & $\begin{array}{l}\text { Hexachloro- } \\
\text { benzene }\end{array}$ \\
\hline JSI & WP & $04 / 16 / 1991$ & $<0.004$ & $<0.004$ & $<0.30$ & $<0.33$ & 4.8 & $<0.39$ & $<0.26$ \\
\hline JS2 & WP & $04 / 16 / 1991$ & $<.004$ & $<.004$ & $<.30$ & $<.33$ & $<.33$ & $<.39$ & $<.26$ \\
\hline JS3 & WP & $04 / 16 / 1991$ & $<.004$ & $<.004$ & $<.30$ & $<.33$ & $<.33$ & $<39$ & $<.26$ \\
\hline JS4 & WP & $04 / 16 / 1991$ & $<.004$ & $<.004$ & $<.30$ & $<.33$ & $<.33$ & $<.39$ & $<.26$ \\
\hline JS5 & WP & $04 / 16 / 1991$ & $<.004$ & $<.004$ & $<.30$ & $<.33$ & $<.33$ & $<.39$ & $<.26$ \\
\hline JS6 & WP & 04/16/1991 & $<.004$ & $<.004$ & $<.30$ & $<.33$ & $<.33$ & $<.39$ & $<.26$ \\
\hline JS7 & WP & $04 / 16 / 1991$ & $<.004$ & $<.004$ & $<30$ & $<33$ & $<.33$ & $<39$ & $<.26$ \\
\hline JS7d & WP & $04 / 16 / 1991$ & $<.004$ & $<.004$ & $<2.0$ & $<2.0$ & $<2.0$ & $<2.0$ & $<1.0$ \\
\hline JS9 & WP & $04 / 16 / 1991$ & $<.004$ & $<.004$ & $<.30$ & $<.33$ & $<.33$ & $<.39$ & $<.26$ \\
\hline JS 10 & WP & $04 / 16 / 1991$ & $<.004$ & $<.004$ & $<.30$ & $<.33$ & $<.33$ & $<.39$ & $<.26$ \\
\hline JS11 & Proto. Bld. & $04 / 12 / 1991$ & $<.004$ & $<.004$ & $<.30$ & $<.33$ & $<.33$ & $<.39$ & $<.26$ \\
\hline JSIId & Proto. Bld. & $04 / 12 / 1991$ & $<.004$ & $<.004$ & $<.30$ & $<.33$ & $<.33$ & $<.39$ & $<.26$ \\
\hline JS13 & Proto. Bld. & $04 / 12 / 1991$ & $<.004$ & $<.004$ & $<.30$ & $<.33$ & $<.33$ & $<.39$ & $<.26$ \\
\hline JS14 & Proto. Bld. & $04 / 12 / 1991$ & $<.004$ & $<.004$ & $<.30$ & $<.33$ & $<.33$ & $<.39$ & $<.26$ \\
\hline JS15 & Proto. Bld. & $04 / 12 / 1991$ & .009 & $<.004$ & $<2.0$ & $<2.0$ & $<2.0$ & $<2.0$ & $<1.0$ \\
\hline JS16 & RCAD & $04 / 12 / 1991$ & $<.004$ & $<.004$ & $<30$ & $<.33$ & $<.33$ & $<39$ & $<.26$ \\
\hline JS17 & RCAD & $04 / 12 / 1991$ & $<.004$ & $<.004$ & $<.60$ & $<.70$ & $<.70$ & $<.80$ & $<.50$ \\
\hline JS17d & RCAD & $04 / 12 / 1991$ & $<.004$ & $<.004$ & $<.30$ & .53 & $<.33$ & $<.39$ & $<.26$ \\
\hline JS19 & RCAD & $04 / 12 / 1991$ & $<.004$ & $<.004$ & $<.30$ & -- & $<.33$ & $<.39$ & $<.26$ \\
\hline JS20 & RCAD & $04 / 12 / 1991$ & $<.004$ & $<.004$ & $<.30$ & $<.33$ & $<.33$ & $<.39$ & $<.26$ \\
\hline JS2I & RCAD & 04/11/1991 & $<.004$ & $<.004$ & $<.30$ & $<.33$ & $<.33$ & $<.39$ & $<.26$ \\
\hline JS22 & RCAD & $04 / 11 / 1991$ & $<.004$ & $<.004$ & $<30$ & .43 & $<.33$ & $<.39$ & $<.26$ \\
\hline JS23 & TMDA & $04 / 11 / 1991$ & $<.004$ & $<.004$ & $<.30$ & $<.33$ & $<.33$ & $<.39$ & $<.26$ \\
\hline JS24 & TMDA & $04 / 11 / 1991$ & $<.004$ & $<.004$ & $<30$ & .60 & $<.33$ & $<.39$ & $<.26$ \\
\hline JS25 & TMDA & $04 / 11 / 1991$ & $<.004$ & $<.004$ & $<.30$ & $<.33$ & .39 & $<.39$ & $<.26$ \\
\hline JS26 & TMDA & $04 / 12 / 1991$ & $<.004$ & $<.004$ & $<30$ & $<.33$ & $<.33$ & $<.39$ & $<.26$ \\
\hline JS26d & TMDA & $04 / 12 / 1991$ & $<.004$ & $<.004$ & $<.30$ & .72 & $<33$ & $<.39$ & $<.26$ \\
\hline JS28 & TMDA & $04 / 12 / 1991$ & $<.004$ & .01 & $<.30$ & $<.33$ & $<.33$ & $<.39$ & $<.26$ \\
\hline JS29 & TMDA & $04 / 12 / 1991$ & $<.004$ & $<.004$ & $<.30$ & .58 & $<.33$ & $<.39$ & .59 \\
\hline JS30 & TMDA & $04 / 12 / 1991$ & $<.004$ & .02 & .53 & $<.33$ & .62 & 1.1 & $<.26$ \\
\hline JS31 & TMDA & $04 / 12 / 1991$ & $<.004$ & $<.004$ & $<.30$ & $<.33$ & $<.33$ & $<.39$ & $<.26$ \\
\hline JS32 & TMDA & $04 / 16 / 1991$ & $<.004$ & $<.004$ & $<.30$ & $<.33$ & $<.33$ & $<.39$ & $<.26$ \\
\hline JS33 & TMDA & $04 / 16 / 1991$ & $<.004$ & $<.004$ & $<30$ & $<.33$ & $<.33$ & $<.39$ & $<.26$ \\
\hline JS34 & TMDA & $04 / 16 / 1991$ & $<.004$ & $<.004$ & $<.30$ & $<.33$ & $<.33$ & $<.39$ & $<.26$ \\
\hline JS36 & TMDA & $04 / 16 / 1991$ & $<.004$ & $<.004$ & $<.30$ & $<.33$ & $<.33$ & -- & $<.26$ \\
\hline JS37 & RP & $04 / 11 / 1991$ & $<.004$ & $<.004$ & $<.30$ & $<.33$ & $<.33$ & $<.39$ & $<.26$ \\
\hline JS38 & RP & $04 / 11 / 1991$ & $<.004$ & $<.004$ & $<.60$ & $<.70$ & $<.70$ & $<.80$ & $<.50$ \\
\hline JS39 & RP & $04 / 11 / 1991$ & $<.004$ & $<.004$ & $<.30$ & .38 & $<.33$ & $<39$ & $<26$ \\
\hline JS40 & $\mathrm{RP}$ & $04 / 11 / 1991$ & $<.004$ & $<.004$ & $<.30$ & .38 & $<.33$ & $<39$ & $<.26$ \\
\hline JS41 & $\mathrm{RP}$ & $04 / 11 / 1991$ & $<.004$ & $<.004$ & $<.30$ & $<.33$ & $<.33$ & $<.39$ & $<.26$ \\
\hline
\end{tabular}




\section{Surface Water}

The marsh south and east of the toxic-materials disposal area collects runoff from the disposal pits and areas east of Ricketts Point Road and south of Robins Point Road (fig. 2). Ground water in the surficial aquifer near the disposal pits discharges to the marsh, providing a continual source of inorganic and organic contaminants.

Depending on the salinity of Chesapeake Bay at the time, surface water in the marsh south and east of the disposal pits is affected by washover of either fresh or brackish water during storms. These washovers can affect the concentrations of inorganic and organic constituents in the marsh either by increasing concentrations of major ions and trace metals or by diluting concentrations of contaminants. The solubility of trace metals also can be affected by changes in the geochemistry caused by the washovers.

Surface-water-sampling sites JFSW6 - JFSW13 are downgradient of the disposal pits in the marsh, and site JFSW14 is in the large open pond in the eastern part of the marsh. The inorganic surfacewater-quality data are shown in table 8 . The concentrations of organic compounds that were detected in surface water at J-Field are shown in table 9.

\section{Inorganic Constituents}

Major-ion concentrations in the spring in the marsh at site JFSW14 and at site JFSW 15 farther east in the marsh were typically 10 to 20 times lower than concentrations at the same sites in the fall. Similar increases were observed in concentrations between the spring and fall at site JFSW20. Storms that wash water from Chesapeake Bay over the barrier beach can affect the concentrations of major ions and trace metals in the marsh. These higher concentrations in the fall are probably caused by evapotranspiration of marsh water and by washover of brackish water that moves up the Chesapeake Bay in the late summer and early fall.

Concentrations of trace metals in surface water at the toxic-materials disposal area are shown in figure 12. Lead concentrations as high as $51 \mu \mathrm{g} / \mathrm{L}$ were detected in surface water near the disposal pits. Other trace metal concentrations were highest at the edge of the marsh, with minimal detections in the pond. Because all surface-water samples at J-Field were collected for analysis of total (suspended plus dissolved) concentrations, trace-metal concentrations in these samples can be greatly affected by suspended sediment that contains high concentrations of trace metals.

Aluminum concentrations in the marsh ranged from below detection limits (less than $50 \mu \mathrm{g} / \mathrm{L}$ ) to $870 \mu \mathrm{g} / \mathrm{L}$ in the spring, and were 1,100 and $6,100 \mu \mathrm{g} / \mathrm{L}$ in the two samples collected in the marsh in the fall. Aluminum concentrations in the bay at site JFSW20 were $2,000 \mu \mathrm{g} / \mathrm{L}$ in the spring of 1993 , and $250 \mu \mathrm{g} / \mathrm{L}$ in the fall. Aluminum concentrations in surface water in the spring of 1989 at Carroll Island (fig. 1) ranged from less than 141 to $2,300 \mu \mathrm{g} / \mathrm{L}$, with a median of $400 \mu \mathrm{g} / \mathrm{L}$ (Tenbus and Phillips, 1996). High variability in the concentrations of total aluminum is related to differences among samples in the amount of colloidal and suspended material (Stumm and Morgan, 1996). The surface-water sample that was collected from the marsh in the fall of 1993 had a concentration of $6,100 \mu \mathrm{g} / \mathrm{L}$ of aluminum and a $\mathrm{pH}$ of 3.7 ; this concentration also may have been enhanced by the higher solubility of aluminum at this low $\mathrm{pH}$. 


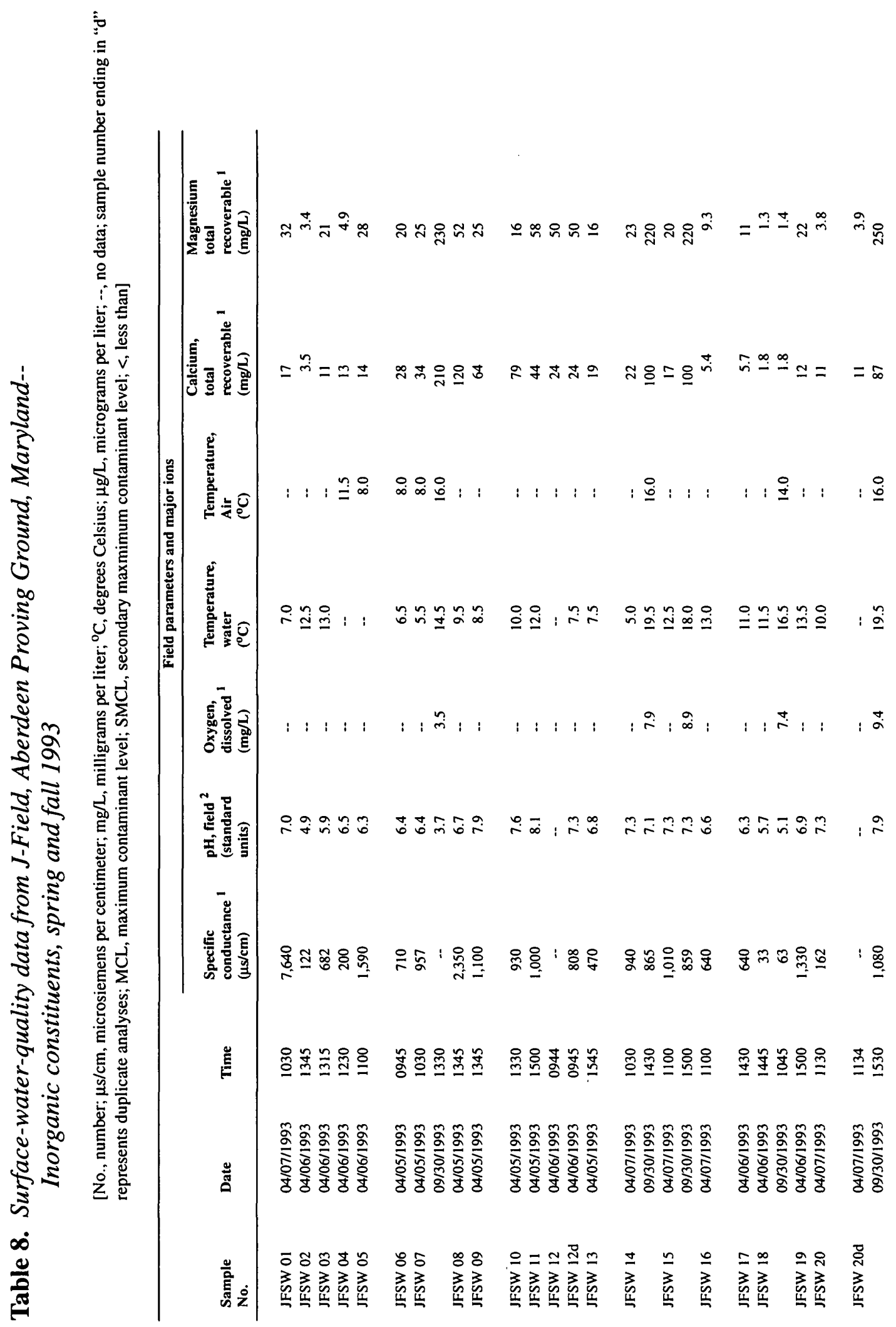




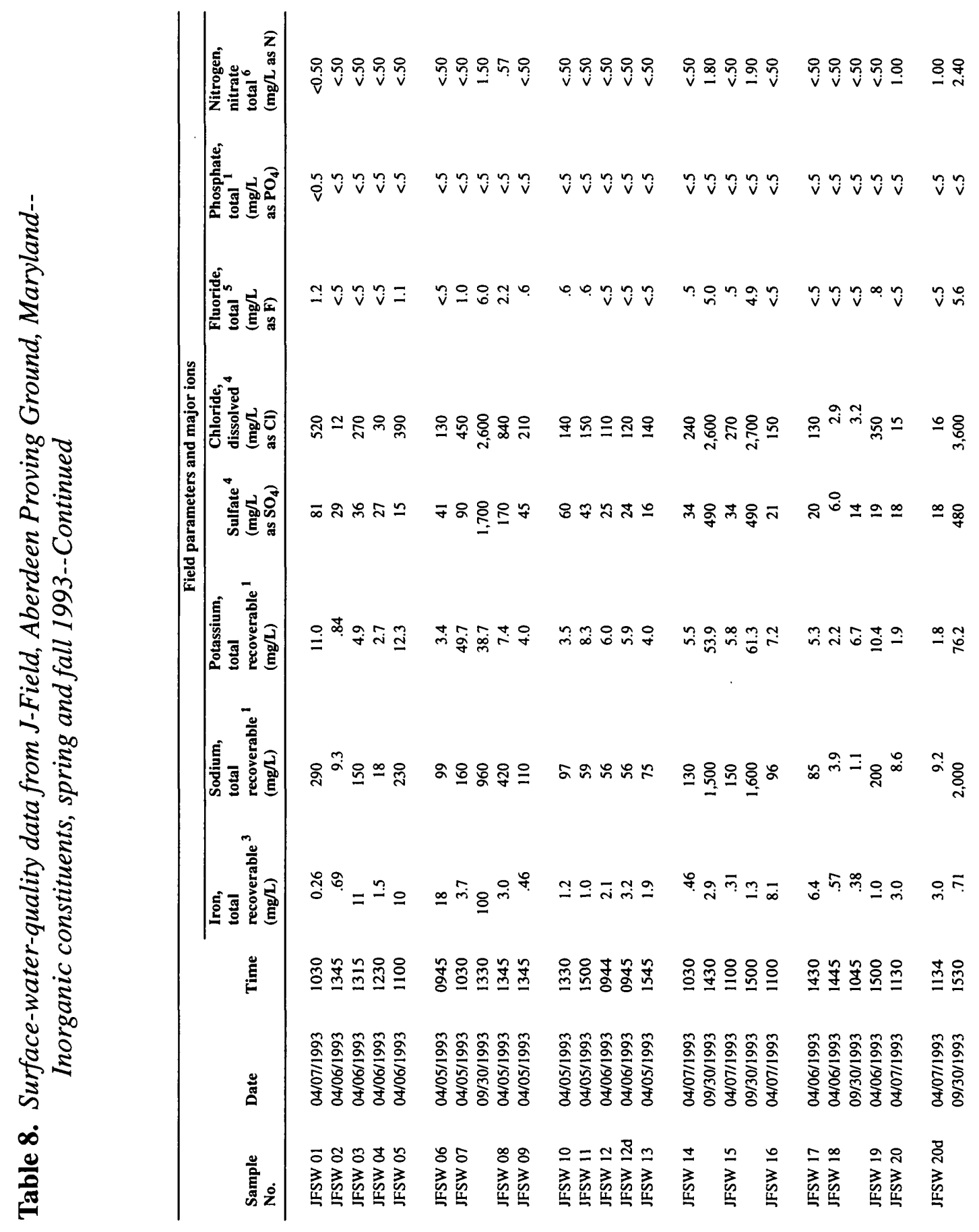




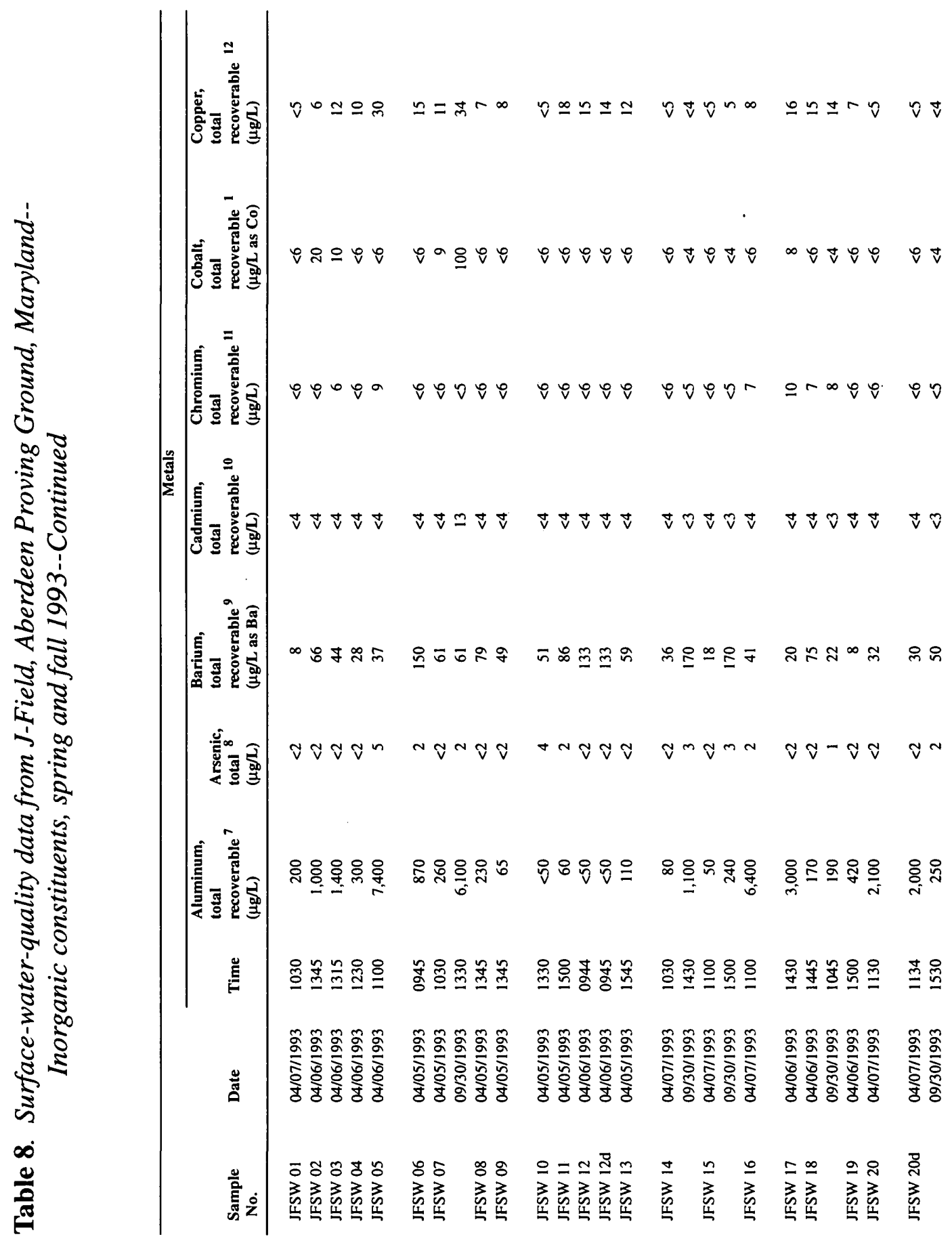




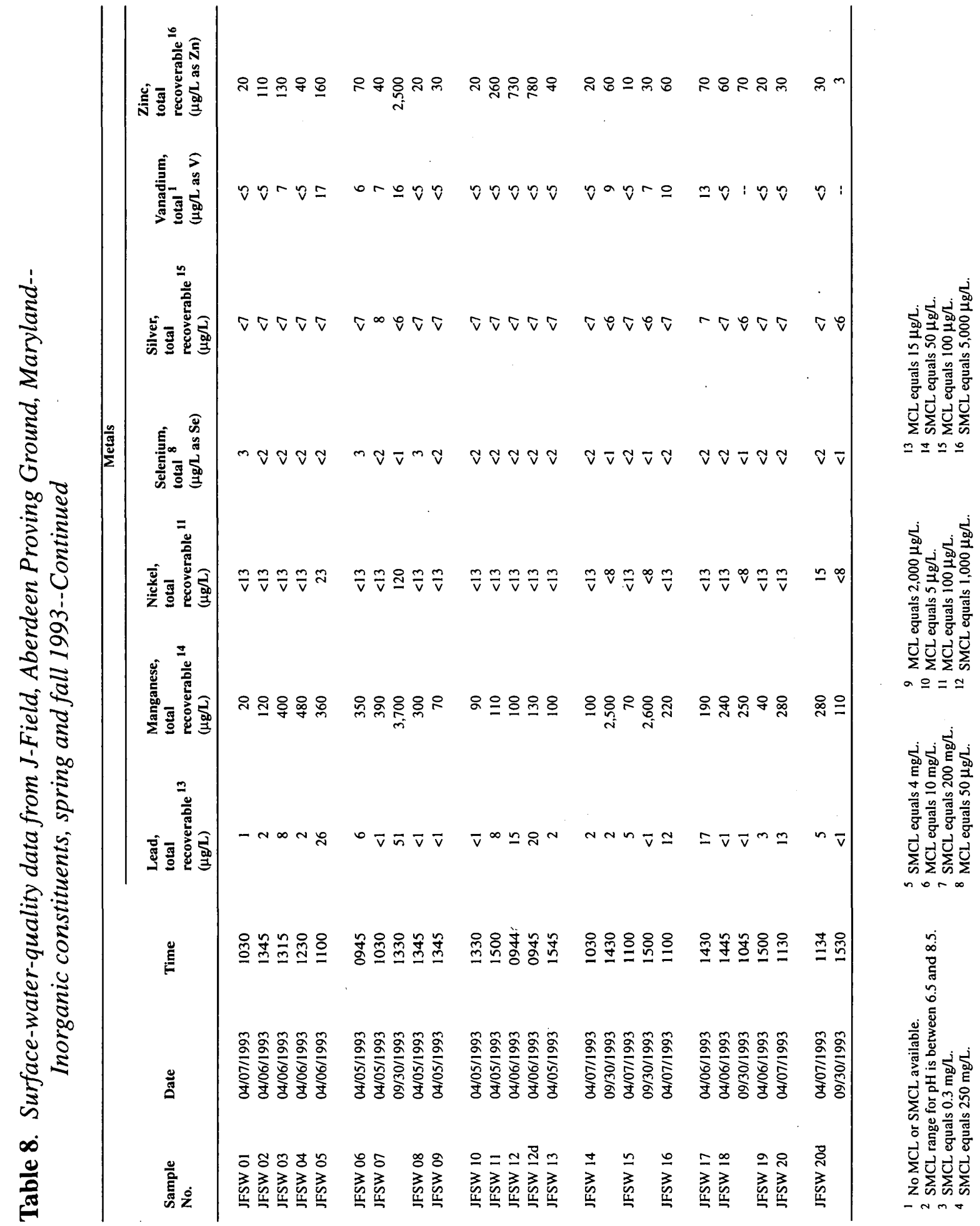




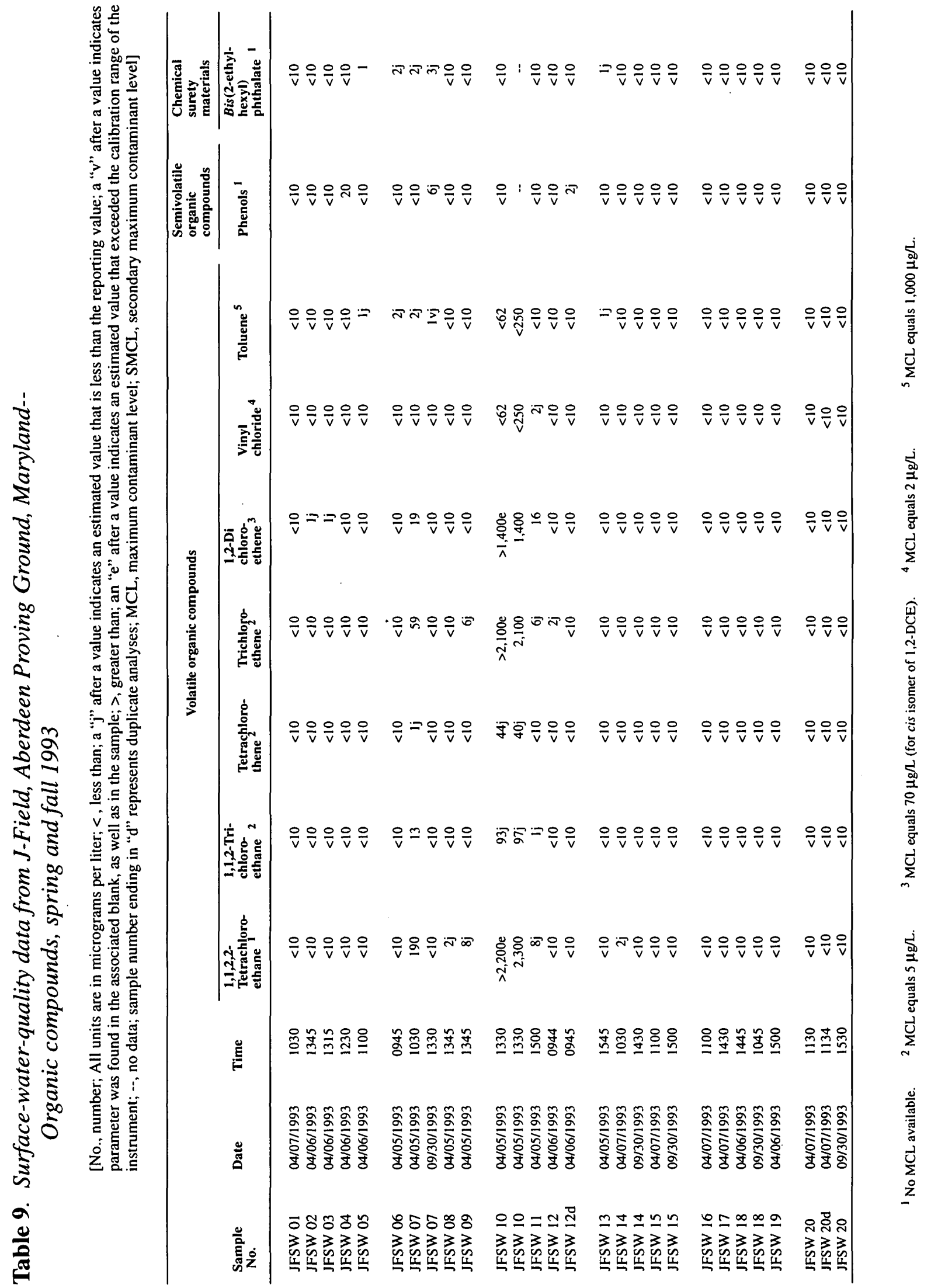




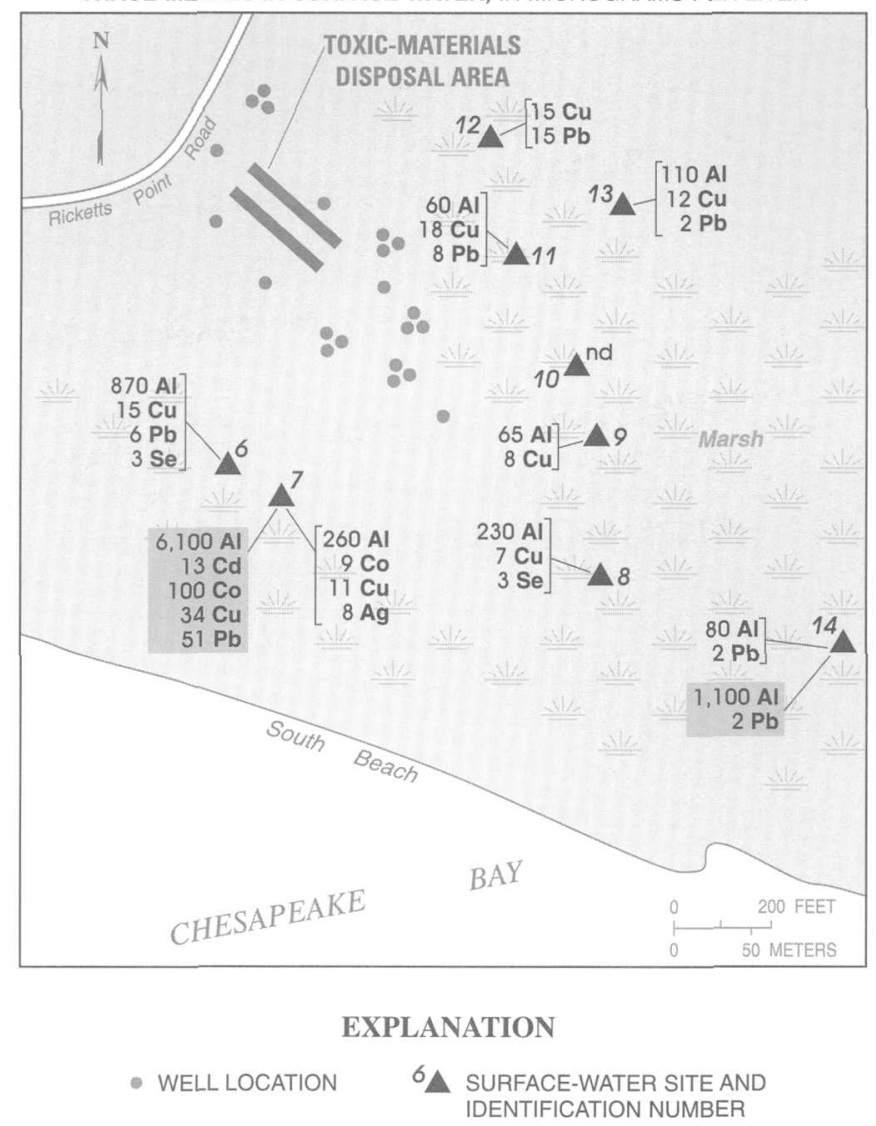

[Ag, silver; Al, aluminum; Cd, cadmium; Co, cobalt; Cu, copper; Pb, lead; Se, selenium; nd, not detected]

(NOTE: All concentrations are in micrograms per liter. Numbers next to brackets represent samples collected in the spring. Numbers in shaded boxes represent samples collected in the fall.)

Figure 12. Concentrations of trace metals detected in surface water at the toxic-materials disposal area, spring and fall 1993 , J-Field, Aberdeen Proving Ground, Maryland.

Cobalt was detected in samples from site JFSW7 in both the spring and fall of 1993, but it was not detected at any other sites at the toxicmaterials disposal area or in the bay at site JFSW20. The concentrations of $9 \mu \mathrm{g} / \mathrm{L}$ in the spring and $100 \mu \mathrm{g} / \mathrm{L}$ in the fall indicate a source of contamination close to site JFSW7. The concentration of cobalt may have increased between the spring and fall because of evapotranspiration. Natural water should contain no more than a few micrograms per liter of cobalt (Hem, 1985). Chromium and mercury were not detected in surface water at the toxic-materials disposal area.

\section{Organic Compounds}

Organic compounds were detected in lower concentrations in surface water than in ground water. The VOC's and SVOC's detected in surface water at J-Field sites are listed in table 9, and the distribution and concentration of VOC's at the toxic-materials disposal area are shown in figure 13. Concentrations of organic compounds were highest and more compounds were detected in samples from surface water closest to the disposal pits compared to samples collected farther from the pits.

The major organic contaminants in surface water at sites JFSW7 and JFSW10 were 1,1,2,2PCA, PCE, 1,1,2-TCA, TCE, and 1,2-Dichloroethylene (DCE) (table 9, fig. 13). The total concentrations of VOC's at these sites and the relative amounts of different VOC's at each site are shown in figure 14. The highest concentrations of VOC's in surface water were found at site JFSW10, which is located immediately downgradient of the toxic-materials disposal area (fig. 8). Total VOC concentrations at this site were approximately $5,900 \mu \mathrm{g} / \mathrm{L}$. The highest 


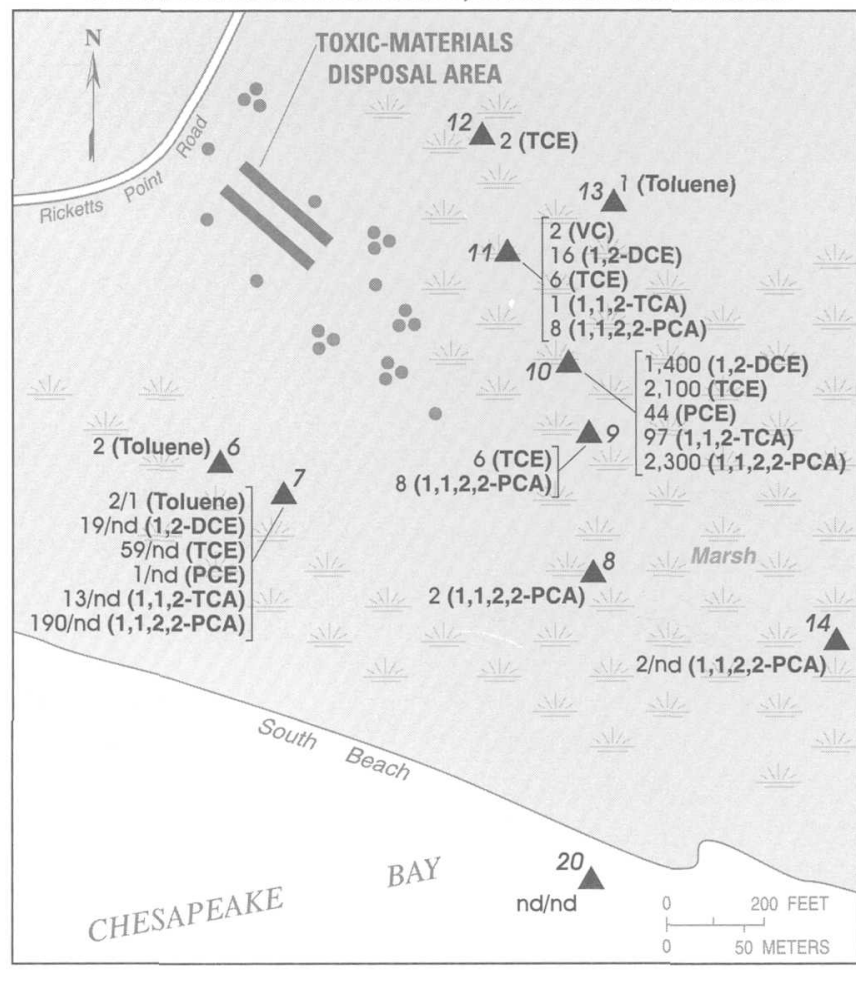

\section{EXPLANATION}

- WELl LOCATION $\quad$ SARFACE-WATER SITE AND
IDENTIFICATION NUMBER

[PCA, tetrachloroethane; TCA, trichloroethane; TCE, trichloroethene; DCE, dichloroethene; VC, vinyl chloride; nd, not detected]

(NOTE: All concentrations are in micrograms per liter. Single concentration values are for spring sampling only. Sites 7 and 14 display concentration values for spring / fall.)

Figure 13. Concentrations of volatile organic compounds detected in surface water at the toxic-materials disposal area, spring and fall 1993, J-Field, Aberdeen Proving Ground, Maryland.

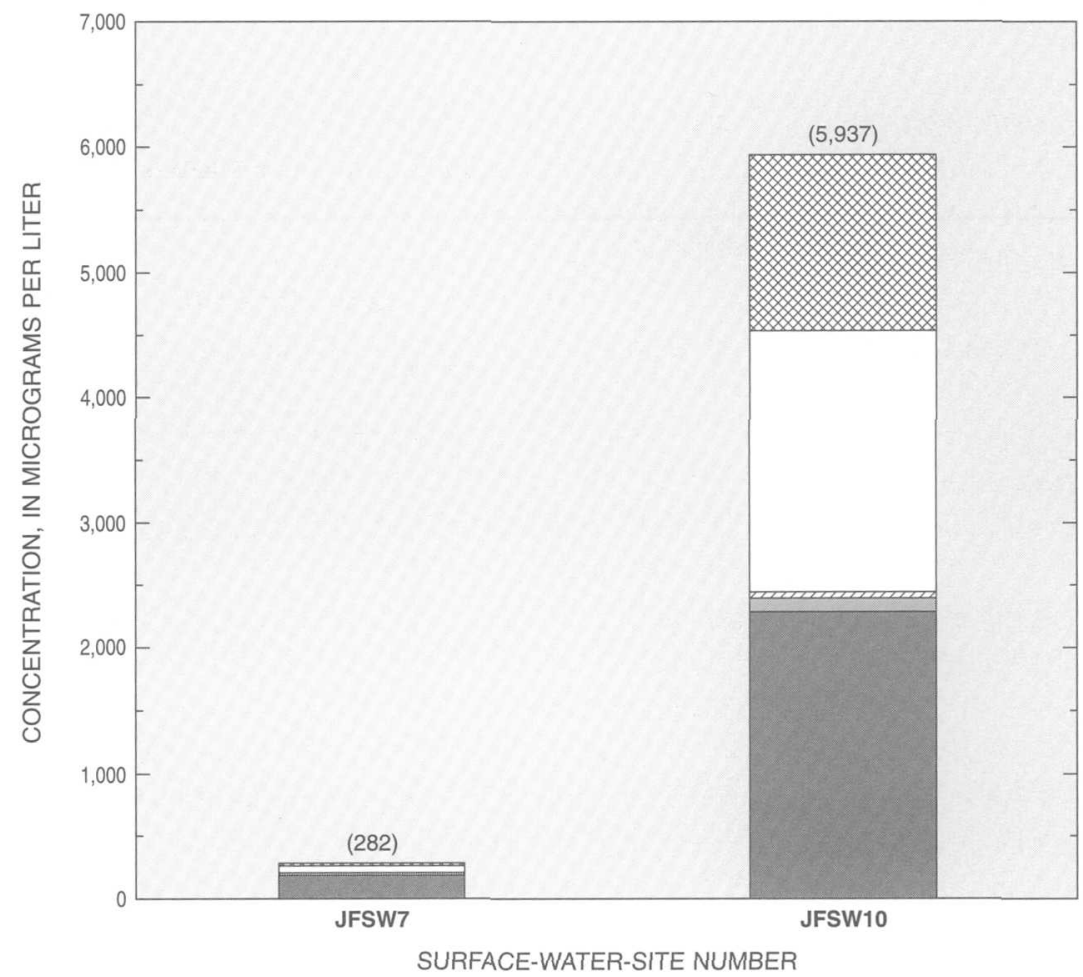

EXPLANATION

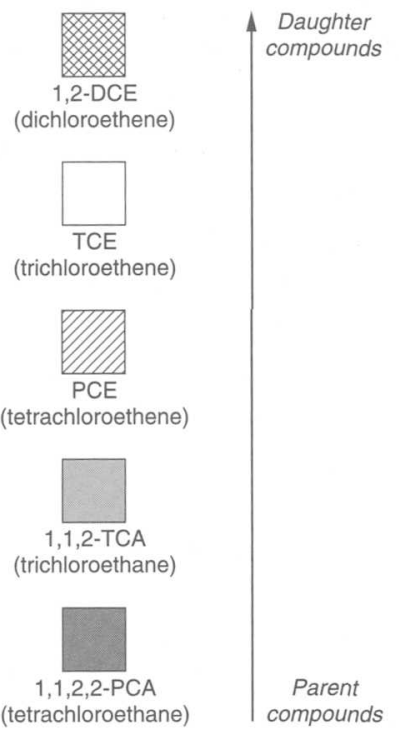

Figure 14. Concentrations of total volatile organic compounds, and the proportions of individual compounds detected in surface water during April 1993 at J-Field, Aberdeen Proving Ground, Maryland. 
concentration of any one compound at site JFSW 10 was $2,300 \mu \mathrm{g} / \mathrm{L}$ of 1,1,2,2-PCA. TCE, PCE, 1,2-DCE, 1,1,2,2-PCE, and 1,1,2-TCA were detected in concentrations above MCL's. These high concentrations are due to discharge of contaminated ground water and surface water to the marsh from the disposal pits. Total VOC's in ground water at upgradient well JF83 (about $300 \mathrm{ft}$ away) were approximately $325,000 \mu \mathrm{g} / \mathrm{L}$.

Some natural attenuation of VOC's may be occurring in the marsh near the toxic-materials disposal area, as indicated by the presence of 1,1,2TCA and 1,2-DCE, which are breakdown products of 1,1,2,2-PCA and TCE, respectively (fig. 14). On the basis of historical information (Nemeth and others, 1983; Nemeth, 1989), 1,1,2,2-PCA, PCE, and TCE are the probable parent compounds in the disposal pit area; however, TCE may result from abiotic breakdown of 1,1,2,2-PCA.

Out of 59 SVOC's that the surface-water samples were analyzed for at J-Field (Phelan and others, 1996), only 3 were detected-- $N$-Nitrosodin-propylamine; phenols; and bis-2-ethylhexyl phthalate, a chemical surety material. $N$-Nitrosodi$n$-propylamine was detected at site JFSW 12 at less than the reporting limit of $10 \mu \mathrm{g} / \mathrm{L}$, but was not detected in the duplicate sample from that site. Concentrations of phenols at the edge of the toxicmaterials disposal area marsh at sites JFSW 7 and JFSW12, were less than the reporting limit of $10 \mu \mathrm{g} / \mathrm{L}$, and probably resulted from natural degradation of plant debris (Thurman, 1986). Bis2-ethylhexyl phthalate was detected at four sites at less than the reporting limit of $10 \mu \mathrm{g} / \mathrm{L}$, and below the MCL of $6 \mu \mathrm{g} / \mathrm{L}$. Because phthalates are commonly used as plasticizers in polymers of vinyl chloride, propylene, ethylene, and styrene (Smith and others, 1988), the bis-2-ethylhexyl phthalate detected at these sites may not be related to chemical testing or disposal activities.

\section{Ground Water}

The following section provides a discussion of field parameters, inorganic constituents, and organic compounds detected in ground water in the surficial aquifer, confining unit, and confined aquifer at the toxic-materials disposal area. The distribution of organic compounds was compared with the soil-gas plumes mapped by Hughes (1993). Twenty-one wells in the vicinity of the toxic-materials disposal area were sampled during at least one of the two phases of ground-water sampling. These 21 wells and the hydrogeologic units they are screened in are listed in the following table.

\begin{tabular}{lll}
\hline $\begin{array}{l}\text { Surficial-aquifer } \\
\text { wells }\end{array}$ & $\begin{array}{l}\text { Confining-unit } \\
\text { wells }\end{array}$ & $\begin{array}{l}\text { Confined-aquifer } \\
\text { wells }\end{array}$ \\
\hline JF43 & JF42* & JF41 \\
JF53 & JF52 & JF5I \\
JF63 & JF62 & JF61 \\
JF73 & JF72 & JF71 \\
JF83 & JF82 & JF81 \\
P1* & \\
P2 & \\
P3 & \\
P4 & \\
P9 & \\
TH4* & \\
$*$ & \\
\end{tabular}

Field Parameters

Ground water in the surficial aquifer immediately beneath and downgradient of the toxicmaterials disposal pits had higher specific conductance values than ground water from the control wells. The median specific-conductance value was $491 \mu \mathrm{S} / \mathrm{cm}$ in ground-water samples taken during Phase I from all wells in the surficial aquifer at the toxic-materials disposal area. This is significantly higher than the median value of $183 \mu \mathrm{S} / \mathrm{cm}$ from the surficial aquifer control wells in Phase I. The specific conductance was greater than $1,000 \mu \mathrm{S} / \mathrm{cm}$ in at least one sampling phase in wells P3, P4, and JF63. The median specific conductance value for wells screened in the confining unit was $638 \mu \mathrm{S} / \mathrm{cm}$ in Phase I, and $481 \mu \mathrm{S} / \mathrm{cm}$ in control wells in this unit. The median specific conductance was $649 \mu \mathrm{S} / \mathrm{cm}$ in ground-water samples taken during Phase I from all of the wells screened in the confined aquifer at the toxicmaterials disposal area, and $433 \mu \mathrm{S} / \mathrm{cm}$ in control wells in this unit. Specific conductance was highest in wells screened in the confining unit and 
in wells screened in the confined aquifer in which the $\mathrm{pH}$ exceeded 8.0. These same trends were observed in Phase II samples from the surficial aquifer, confining unit, and confined aquifer, although fewer wells were sampled in the confining unit and confined aquifer during Phase II than Phase I.

Typical $\mathrm{pH}$ values for ground water in control wells at J-Field ranged from 4.6 to 7.8 . Median $\mathrm{pH}$ values were slightly higher in all wells in the surficial aquifer at the toxic-materials disposal area (6.0 and 6.3 in Phases I and II, respectively) than in all the surficial-aquifer control wells at J-Field (5.5 and 5.2 in Phases I and II, respectively). Median $\mathrm{pH}$ values for wells with $\mathrm{pH}$ less than 8.0 in the confining unit and the confined aquifer were similar to those in the control wells. The $\mathrm{pH}$ exceeded 8.0 in six wells at the toxic-materials disposal area-JF72 ( $\mathrm{pH}=12.4)$ and JF82 ( $\mathrm{pH}=11.9)$ in the confining unit, and in wells JF51 ( $\mathrm{pH}=9.1), \mathrm{JF} 61$ ( $\mathrm{pH}=12.0), \mathrm{JF71}(\mathrm{pH}=11.2)$, and JF81 ( $\mathrm{pH}=9.6)$ in the confined aquifer (fig. 15).

The median alkalinity in the surficial aquifer in the Phase I samples from the toxic-materials disposal area was $83 \mathrm{mg} / \mathrm{L}$ [as calcium carbonate $\left.\left(\mathrm{CaCO}_{3}\right)\right]$, which was considerably higher than the median concentration of $6.5 \mathrm{mg} / \mathrm{L}$ in all control wells in this aquifer at J-Field. Alkalinity values were high in wells in which the $\mathrm{pH}$ exceeded 8.0. In Phase I samples from wells JF72 and JF82, which are confining unit wells in which the $\mathrm{pH}$ exceeded 8.0, the alkalinity values were 700 and $460 \mathrm{mg} / \mathrm{L}$, respectively, which are significantly above the median value of $230 \mathrm{mg} / \mathrm{L}$ in all the control wells screened in this unit. In Phase I samples from wells JF51, JF61, and JF81, which are wells screened in the confined aquifer in which the $\mathrm{pH}$ exceeded 8.0 , alkalinity values are 280 , 400 , and $188 \mathrm{mg} / \mathrm{L}$, respectively, which are all above the median value of $180 \mathrm{mg} / \mathrm{L}$ in all the control wells in this unit.

Three hypotheses were evaluated concerning the high $\mathrm{pH}$ and high alkalinity values in ground water from wells that are downgradient of the disposal areas. The first hypothesis is that burning activities contributed to the elevated $\mathrm{pH}$ and alkalinity values. The typical procedures for openpit burning were to place wood dunnage in the disposal pit, add the chemical agents, munitions, and other chemical wastes, and then flood the pit with a hydrocarbon fuel, such as fuel oil. The fuel was ignited and the containers were opened by an explosive charge. The lye (sodium hydroxide), potash (potassium carbonate), and other compounds that were generated from the burning wood dunnage may have contributed to the elevated $\mathrm{pH}$ and alkalinity values downgradient of the disposal areas.

The second hypothesis concerning the high $\mathrm{pH}$ and alkalinity values downgradient of the toxicmaterials disposal area involves the bulk sodium hydroxide, which may have contained impurities of potassium hydroxide that was added to the disposal pits to neutralize chemical nerve agents. Excess hydroxide ions may have caused elevated $\mathrm{pH}$ and alkalinity values because hydroxide ions are titrated in addition to carbonate species in the application of the alkalinity titration method.

A third hypothesis for the elevated $\mathrm{pH}$ and alkalinity values in samples from these wells is the possibility of contamination from cement grout used during well installation. Contact between ground water and grout can occur if wells are not properly constructed, and can result in elevated $\mathrm{pH}$ values (Walker, 1983; Williams and Evans, 1987). Cement-grout dissolution can result from contact with high ionic strength waters, or with organicsolvent contaminants, both of which can affect the mixing and hardening of the grout and result in high $\mathrm{pH}$ values. Cement-grout contamination is an unlikely explanation, however, for the high $\mathrm{pH}$ values in samples from wells in the confining unit and confined aquifer at J-Field. Lorah and Vroblesky (1989) showed that grout dissolution produced a high $\mathrm{pH}$ brine solution with concentrations of $1,500 \mathrm{mg} / \mathrm{L}$ of potassium and $2,140 \mathrm{mg} / \mathrm{L}$ of bicarbonate. Although potassium concentrations in the wells at J-Field with $\mathrm{pH}$ values greater than 8.0 were up to 70 times greater than concentrations from control wells, bicarbonate concentrations (as determined by alkalinity titration) were only up to twice as high as concentrations in control wells. In addition, the affected wells are not randomly spatially distributed--these wells are all immediately downgradient of the toxic-materials disposal area and the white-phosphorus disposal area, the two most contaminated sites sites at J-Field. 


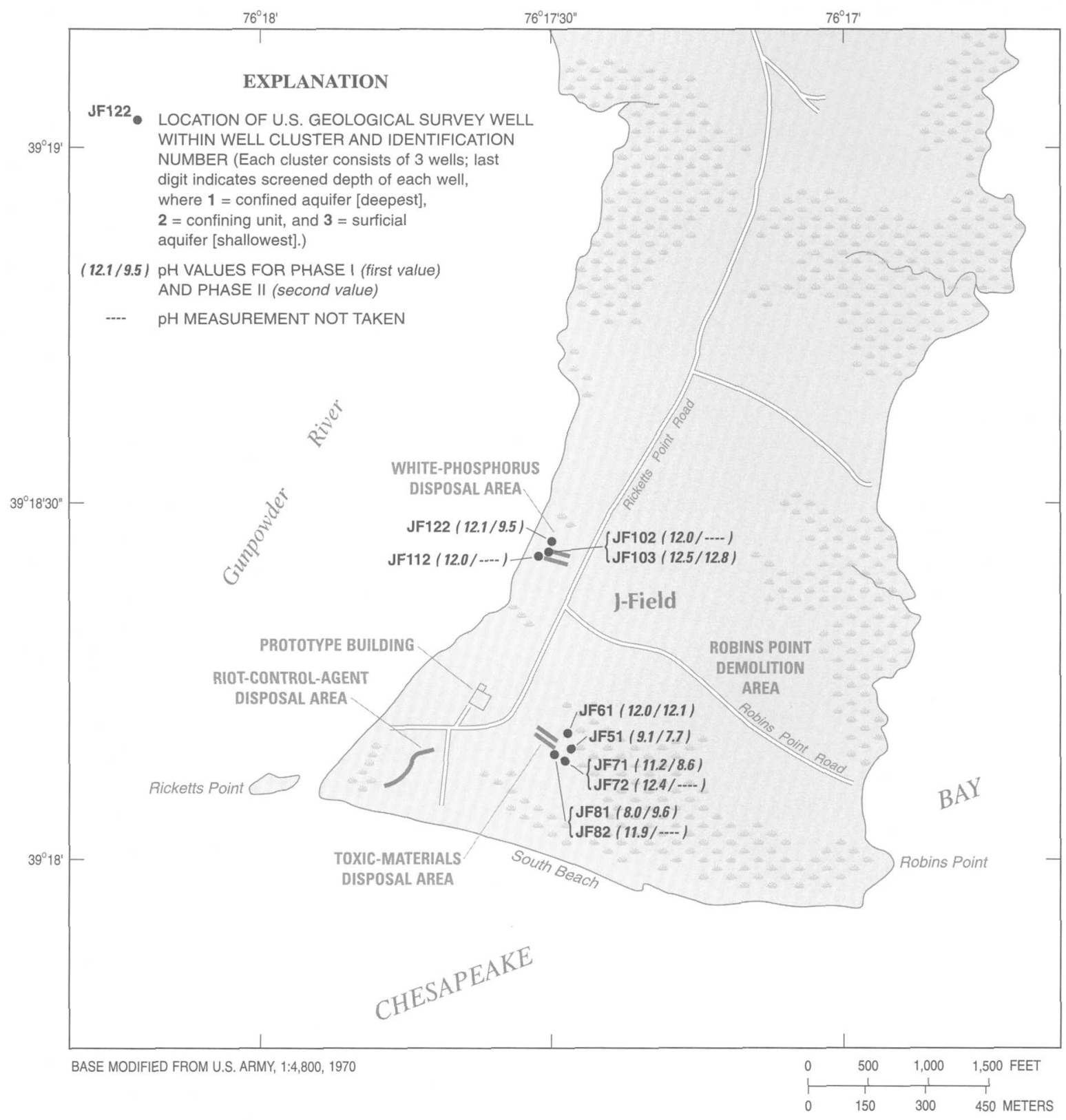

Figure 15. Distribution of $\mathrm{pH}$ values greater than 8.0 in wells at J-Field, Aberdeen Proving Ground, Maryland. 
The chemistry of samples with high $\mathrm{pH}$ values is distinctly different from samples taken at control wells. Water from wells with a pH greater than 8.0 screened in the confining unit had significantly higher potassium, slightly higher alkalinity (bicarbonate), and significantly lower concentrations of magnesium and iron (below the detection limits) than wells with a $\mathrm{pH}$ less than 8.0. Water from wells with a $\mathrm{pH}$ greater than 8.0 in the confined aquifer also had high alkalinity and potassium, but not all of the samples contained lower concentrations of magnesium and iron.

At the toxic-materials disposal area, the median dissolved oxygen concentration in the surficial aquifer during Phase I was $1.1 \mathrm{mg} / \mathrm{L}$, compared to the median concentration of $8.0 \mathrm{mg} / \mathrm{L}$ from control wells in the same aquifer. The lower dissolved oxygen concentrations in the surficial aquifer near the disposal pits were most likely due to anaerobic conditions generated as organic chemicals were metabolized in the aquifer.

\section{Inorganic Constituents}

At the toxic-materials disposal area, concentrations of magnesium, manganese, potassium, and chloride and specific conductance values from wells in the surficial aquifer with $\mathrm{pH}$ less than 8.0 were slightly higher than those concentrations typically found in control wells at J-Field. Majorion concentrations from wells in the confining unit and confined aquifer with $\mathrm{pH}$ less than 8.0 at the toxic-materials disposal area were similar to concentrations in control wells at J-Field. The high concentrations of dissolved sodium $(670 \mathrm{mg} / \mathrm{L})$, chloride $(1,300 \mathrm{mg} / \mathrm{L})$, and sulfate $(320 \mathrm{mg} / \mathrm{L})$ in well JF133 indicate brackish-water intrusion, particularly in comparison to concentrations of these ions in the control wells. Well JF133 is now (1997) located approximately $25 \mathrm{ft}$ from South Beach; the South Beach demolition area has been completely eroded. Brackish water has been observed washing over the beach and covering the ground at the well, allowing the water to percolate downward toward the well screen.
Trace metals detected during Phase I sampling at the toxic-materials disposal area included dissolved aluminium, antimony, arsenic, barium, boron, nickel, and zinc (table 10). Lead was not detected in ground water although it was detected in soils and surface-water samples, indicating that it is partially bound in soils at the site. Barium was detected in all wells at J-Field at levels less than $270 \mu \mathrm{g} / \mathrm{L}$ (Phelan and others, 1996), which is below the MCL of $2,000 \mu \mathrm{g} / \mathrm{L}$. Some concentrations of aluminium, antimony, arsenic, and nickel were above those measured in control wells, and at concentrations that exceeded the MCL's, indicating that disposal activities have released trace metals to the ground water. Because the ground-water samples for dissolved constituents were filtered through a 0.45 -micron filter rather than a 0.1-micron filter, some particulate aluminum could have remained in the sample, which could have increased the dissolved aluminum concentration. The only concentrations of aluminum that exceeded MCL's were detected in samples from the following wells with high $\mathrm{pH}$ values: JF72, with a $\mathrm{pH}$ of 12.4 ; JF82, with a pH of 11.9 ; and JF61, with a pH of 12.0. As $\mathrm{pH}$ exceeds about 9.0, the solubility of aluminum is high enough that water could contain several thousand milligrams per liter (Hem, 1985). Antimony was detected in only one well (JF82), at a concentration of $67 \mu \mathrm{g} / \mathrm{L}$. Because antimony is used in the manufacture of munitions, this concentration could be a result of munitions disposal or detonation.

Phase II samples from the toxic-materials disposal area were not analyzed for aluminum, antimony, boron, and nickel. The concentration of vanadium, which was not detected in any Phase I samples, in well JF82 was $20 \mu \mathrm{g} / \mathrm{L}$; it was the only trace metal analyzed for in the Phase II samples that was detected above concentrations found in control wells. 
Table 10. Dissolved trace metals detected in ground water at the toxic-materials disposal area during Phase I sampling, May-June 1990, J-Field, Aberdeen Proving Ground, Maryland

[All concentrations are in micrograms per liter $(\mu \mathrm{g} / \mathrm{L})$. SMCL, secondary maximum contaminant levels; $\mathrm{MCL}$, maximum contaminant levels; BOLD numbers indicate concentrations that exceed MCL's or SMCL's; * indicates wells with pH higher than $8 ;--$, data not available; $<$, less than]

\begin{tabular}{|c|c|c|c|c|c|c|c|c|}
\hline $\begin{array}{l}\text { Well } \\
\text { No. }\end{array}$ & Hydrogeologic unit & Aluminum ${ }^{1}$ & Antimony ${ }^{2}$ & Arsenic $^{3}$ & Barium ${ }^{4}$ & Boron 5 & Nickel ${ }^{6}$ & Zinc $^{7}$ \\
\hline $\mathrm{P} 3$ & Surficial aquifer & $<110$ & $<60$ & 30 & 55 & 2,500 & $<32$ & 62 \\
\hline P4 & Surficial aquifer & 120 & $<60$ & $<2$ & 74 & -- & $<32$ & 290 \\
\hline JF53 & Surficial aquifer & $<110$ & $<60$ & $<2$ & 93 & $<230$ & 440 & 36 \\
\hline JF63 & Surficial aquifer & $<110$ & $<60$ & 4 & 110 & $<230$ & $<32$ & 19 \\
\hline JF73 & Surficial aquifer & $<110$ & $<60$ & 6 & 56 & $<230$ & $<32$ & $<18$ \\
\hline JF83 & Surficial aquifer & $<110$ & $<60$ & 60 & 120 & $<230$ & $<32$ & 29 \\
\hline JF72* & Confining unit & 340 & $<60$ & $<2$ & 77 & $<230$ & $<32$ & $<18$ \\
\hline JF82* & Confining unit & 430 & 67 & 21 & 140 & $<230$ & $<32$ & $<18$ \\
\hline JF4 1 & Confined aquifer & $<110$ & $<60$ & 4 & 110 & $<230$ & $<32$ & $<18$ \\
\hline JF61* & Confined aquifer & 780 & $<60$ & 8 & 76 & $<230$ & $<32$ & $<18$ \\
\hline JF7 1* & Confined aquifer & $<110$ & $<60$ & 3 & 52 & $<230$ & $<32$ & $<18$ \\
\hline 1 & SMCL equals $200 \mu \mathrm{g} / \mathrm{L}$. & & \multirow{4}{*}{\multicolumn{2}{|c|}{$\begin{array}{l}5 \text { No MCL reported. } \\
6 \text { MCL equals } 100 \mu \mathrm{g} / \mathrm{L} \text {. } \\
{ }^{6} \text { SMCL equals } 5,000 \mu \mathrm{g} / \mathrm{L} \text {. }\end{array}$}} & & & & \\
\hline 2 & MCL equals $6 \mu \mathrm{g} / \mathrm{L}$. & & & & & & & \\
\hline 3 & MCL equals $50 \mu \mathrm{g} / \mathrm{L}$. & & & & & & & \\
\hline 4 & MCL equals $2,000 \mu \mathrm{g} / \mathrm{L}$. & & & & & & & \\
\hline
\end{tabular}

\section{Organic Compounds}

During Phase I, 23 organic compounds were detected in ground-water samples from the toxicmaterials disposal area (table 11). Concentrations of 36 other organic compounds did not exceed the reporting limits. During Phase II, 11 organic compounds were detected (table 12). Concentrations of 106 additional organic compounds that were analyzed for did not exceed the reporting limits (Phelan and others, 1996).

The highest concentrations of organic compounds in ground water in the surficial aquifer downgradient of the disposal pits did not always correlate spatially with the highest relative-flux measurements in the soil gas (fig. 10). Soil-gas concentrations are subject to great variability. Discontinuous clay lenses in the surficial aquifer also could have affected the movement of soil gas from the water table to the land surface. In addition, concentrations of VOC's in the ground water could have changed between the soil-gas sampling (February to March 1989) and the Phase I ground-water sampling (May to June 1990). 


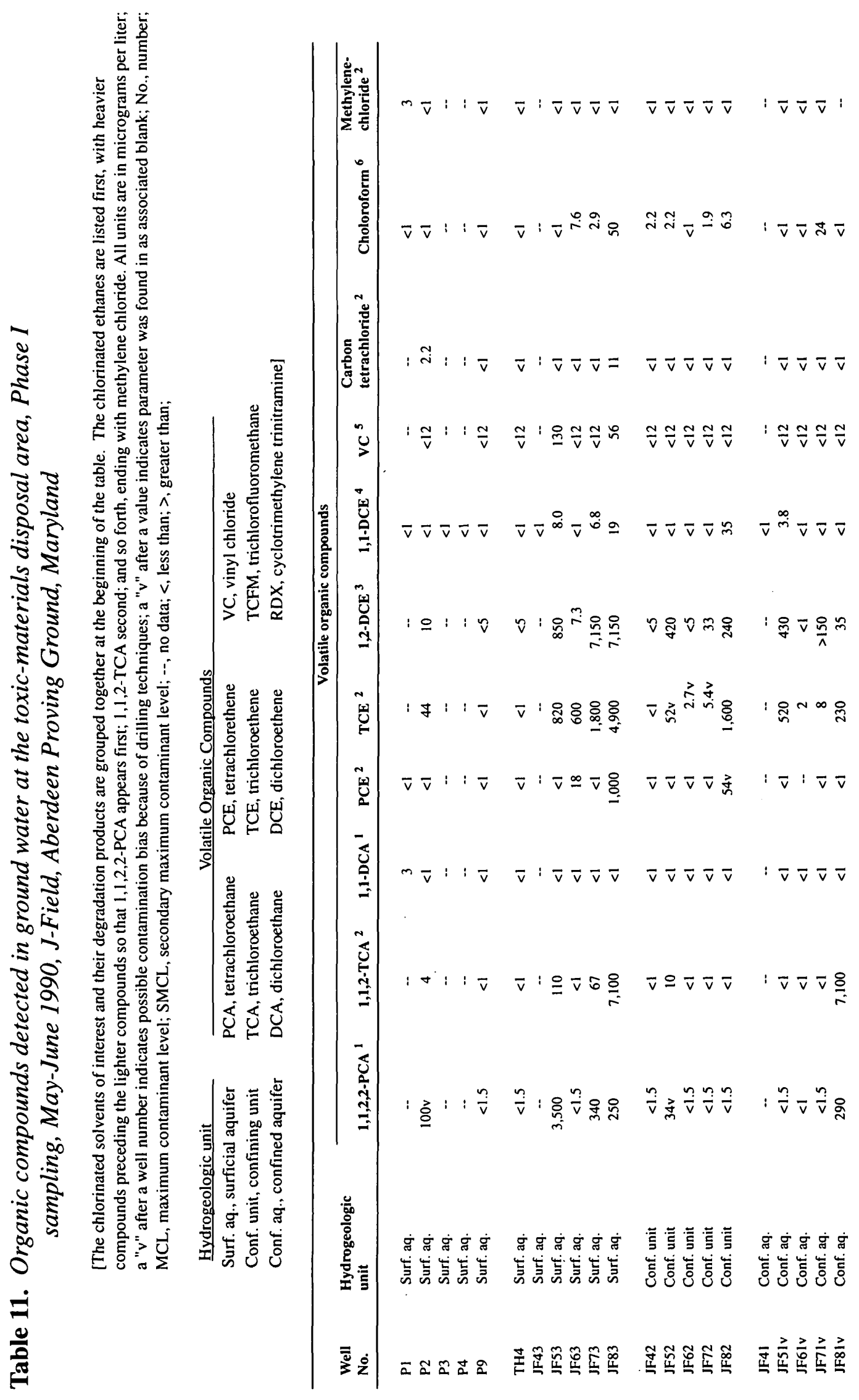




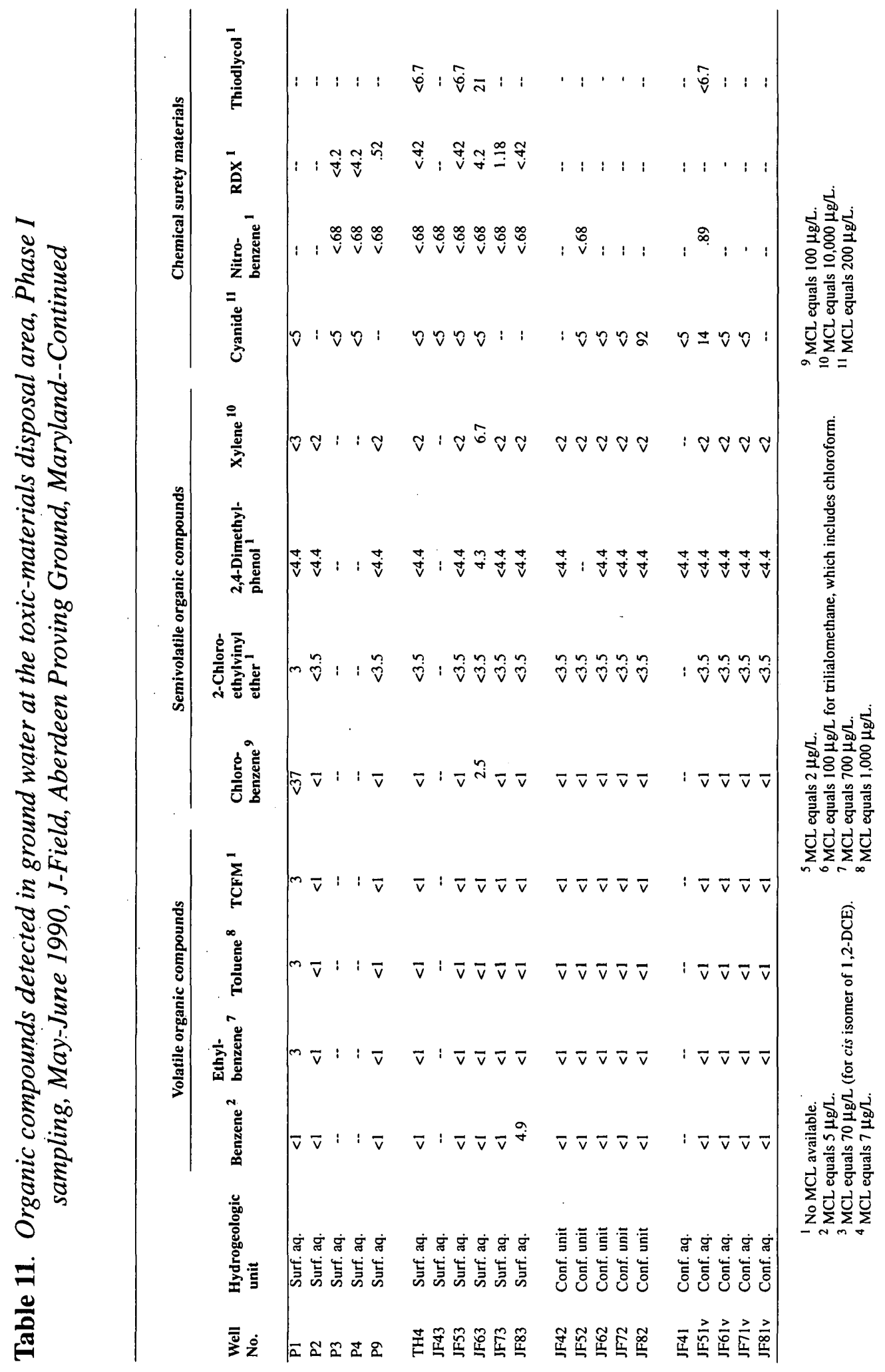




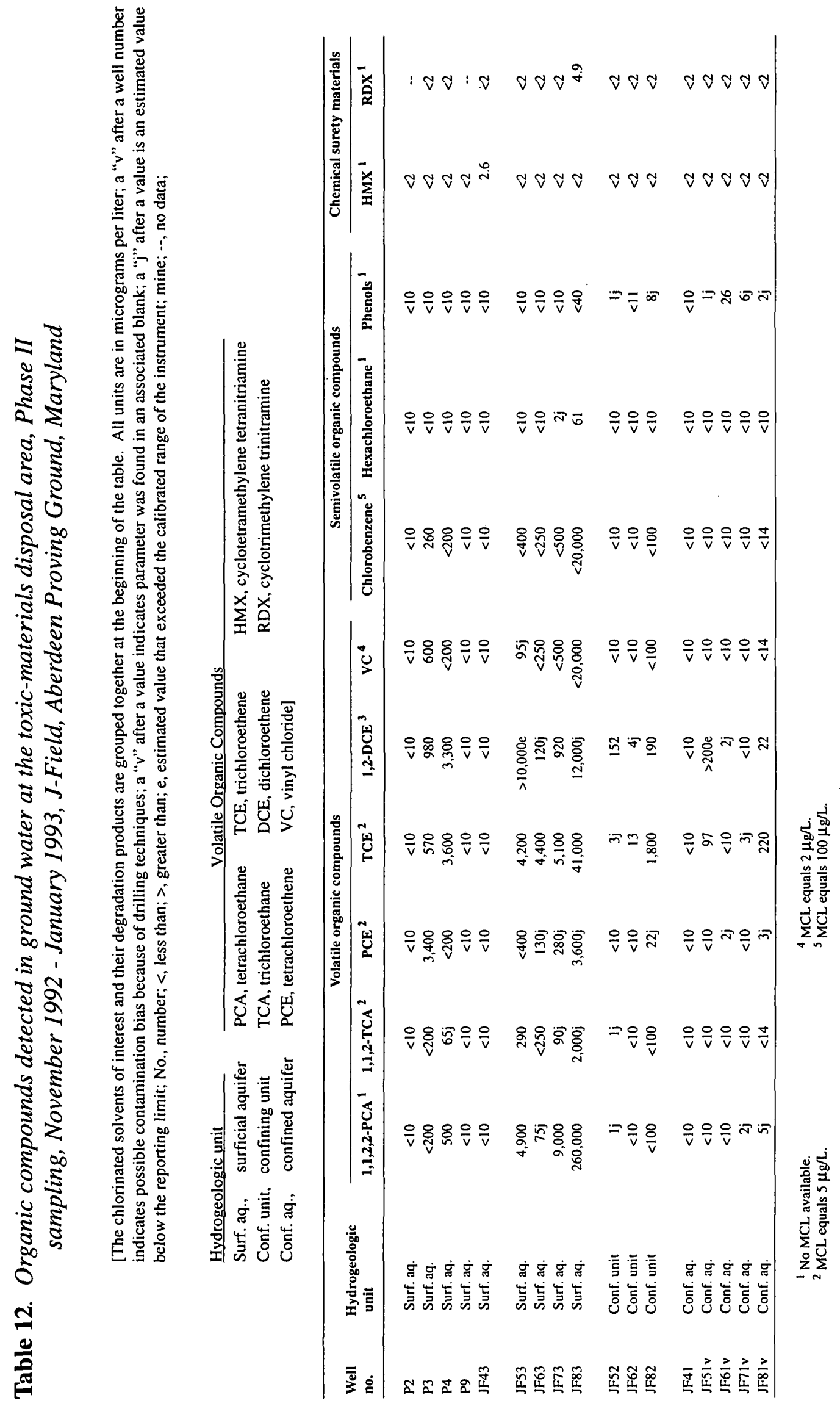


The concentrations of VOC's in Phase I and II ground-water samples from wells downgradient of the toxic-materials disposal area are shown in figures $16 \mathrm{a}$ and 16b. The VOC's with the highest concentrations in the surficial aquifer during Phase I and II, and the changes in the maximum concentrations between Phases I and II are shown below.

\begin{tabular}{|c|c|c|c|}
\hline \multirow[t]{2}{*}{ Compound } & \multicolumn{3}{|c|}{$\begin{array}{l}\text { Maximum concentrations in microgram per liter } \\
(\mu \mathrm{g} / \mathrm{L}) \text { in the surficial aquifer, (and the well in which } \\
\text { the consentrations were detected) }\end{array}$} \\
\hline & Phase I & Phase II & Trend \\
\hline $1,1,2,2-\mathrm{PCA}$ & 3,500 (JF53) & $260,000(\mathrm{JF} 83)$ & $\begin{array}{l}\text { Greatly } \\
\text { increased }\end{array}$ \\
\hline $1,1,2-\mathrm{TCA}$ & $7,100(\mathrm{JF} 83)$ & $2,000(\mathrm{JF} 83)$ & Decreased \\
\hline TCE & 4,900 (JF83) & 41,000 (JF83) & $\begin{array}{l}\text { Greatly } \\
\text { increased }\end{array}$ \\
\hline 1,2-DCE & $\begin{array}{c}7,150(\mathrm{JF73} \text { and } \\
83)\end{array}$ & $12,000(\mathrm{JF83})$ & Increased \\
\hline
\end{tabular}

Total VOC concentrations in wells screened in the surficial aquifer downgradient of the disposal pits (JF53, JF63, JF73, JF83) increased considerably between Phases I and II (figs. 16a and 16b). Possible reasons for this may include (1) ground water at the toxic-materials disposal area is highly variable in its composition; (2) a plume of more heavily contaminated ground water moved into the vicinity of these wells; and (3) ground water in the vicinity of the well screens may not have reached equilibrium with ground water in the aquifer before Phase I sampling, resulting in lower concentrations than were actually present. The $260,000 \mu \mathrm{g} / \mathrm{L}$ concentration of 1,1,2,2-PCA in well JF83 in Phase II was at about 10 percent of its aqueous solubility at ground-water temperature (Montgomery and Welcom, 1990). This high concentration of 1,1,2,2-PCA, relative to its solubility, indicates the presence of dense nonaqueous phase liquid (DNAPL) in the surficial aquifer.

1,1,2,2-PCA, PCE, and TCE are the most likely contaminants that would have been disposed of at the disposal pits. Because 1,1,2,2-PCA can degrade to PCE, and PCE can degrade to TCE, it is not possible to differentiate concentrations of PCE and TCE due to disposal activities from those due to degradation of the 1,1,2,2-PCA. Vinyl chloride (VC) and 1,2-DCE are daughter compounds of
TCE, and considerable amounts of these two compounds have been detected in wells JF53, JF73, and JF83, which are downgradient of the disposal pits (figs $16 \mathrm{a}$ and 16b). The presence of $\mathrm{VC}$ and 1,2-DCE indicates that some degree of natural attenuation of VOC's is occurring within the toxicmaterials disposal area.

The VOC's with the highest maximum concentrations during Phase I and II in the wells screened in the confining unit are shown below.

\begin{tabular}{|c|c|c|}
\hline \multirow[t]{2}{*}{ Compound } & \multicolumn{2}{|c|}{$\begin{array}{l}\text { Maximum concentrations in micrograms per liter } \\
(\mu \mathrm{g} / \mathrm{L}) \text { in the confining unit, (and the well in which } \\
\text { the concentrations were detected) }\end{array}$} \\
\hline & Phase I & Phase II \\
\hline TCE & $1,600(\mathrm{JF} 82)$ & $1,800(\mathrm{JF} 82)$ \\
\hline \multirow[t]{2}{*}{ 1,2-DCE } & 240 (JF82) & 190 (JF82) \\
\hline & 420 (JF52) & 152 (JF52) \\
\hline 1,1-DCE & 35 (JF82) & $<100(\mathrm{JF} 82)$ \\
\hline
\end{tabular}

The VOC concentrations in these wells and in JF62 and JF72, which are downgradient of the disposal pits, did not change appreciably between Phase I and II (figs. 16a and 16b), probably because the rate of ground-water movement in the confining unit is slow. In addition, these wells may have been contaminated by drilling operations, with the contaminants remaining near the well screen during the interval between the sampling phases. Because of this possibility, it is not as likely that the VOC's detected in the confining-unit wells were caused by extensive contamination of the confining unit at the toxic-materials disposal area.

In the confined aquifer, concentrations of 1,1,2,2-PCA and 1,1,2-TCA in well JF81 during Phase I sampling were similar to those detected in the surficial aquifer in well JF83 (fig 16a).

Concentrations of VOC's declined substantially in each of the confined-aquifer wells downgradient of the disposal pits (JF51, JF61, JF71, and JF81) between Phase I and II (figs. 16a and 16b). This decline suggests that the drilling process was the source of VOC contamination in the confined aquifer and that natural attenuation, primarily in the form of dilution, has been occurring and that there is not a continuous source of contaminants to the aquifer. 
Chemical surety materials (CSM) detected during Phase I sampling (table 11) in ground water near the disposal pits included cyanide, nitrobenzene, RDX (cyclotrimethylene trinitramine, an explosive), and thiodiglycol. HMX (cyclotetramethylene tetranitramine, an explosive) and RDX were detected during Phase II sampling (table 12). The cyanide concentrations of $92 \mu \mathrm{g} / \mathrm{L}$ in well JF82 and $14 \mu \mathrm{g} / \mathrm{L}$ in well JF51 in Phase I sampling were below the MCL of $200 \mu \mathrm{g} / \mathrm{L}$. No specific CSM compounds were detected in any given well during both Phase I and II sampling.

\section{Contamination at the Toxic-Materials Disposal Area}

Concentrations of the trace metals antimony, cadmium, copper, chromium, lead, and mercury in soils at the toxic-materials disposal area were well in excess of concentrations typically found in the Talbot Formation. The extent of trace-metal contamination indicated a local source, primarily at the edge of the marsh where debris was pushed from the burn pits. Concentrations of TCE, which was the only VOC detected in soils in the area, were near the minimum reporting limit at two sites. This indicated that organic contamination of soils at the toxic-materials disposal area was not as extensive as indicated in the soil-gas sampling.

Lead concentrations as high as $51 \mu \mathrm{g} / \mathrm{L}$ were detected in surface water near the disposal pits. Other trace metal concentrations in surface water were highest at the edge of the marsh, with minimal detections in the pond. The higher concentrations of metals at the edge of the marsh could result from particulate matter because the surface-water samples were analyzed for total rather than dissolved constituents. If the high concentrations of trace metals are due to particulate matter, then the particles are probably bound in the organic sediments at the edge of the marsh and are, therefore, not transferred to the pond. It also is possible that the high concentration of trace metals are due to dissolved concentrations resulting from the discharge of anoxic ground water. If this is the case, then the change to oxic conditions in the surface water may cause the precipitation of the trace metals, binding them to the organic sediments and preventing them from reaching the pond.
The highest concentrations of organic contaminants in surface water included 1,1,2,2PCA, PCE, TCE, and 1,2-DCE, and were at sites JFSW7 and JFSW10, at the edges of the marsh immediately downgradient of the disposal pits. 1,1,2,2-PCA, PCE, and TCE are the probable parent compounds in the disposal pit area. PCE and TCE at site JFSW10 also may be the result of the breakdown of the 1,1,2,2-PCA. The high concentrations of $1,2-\mathrm{DCE}(1,400 \mu \mathrm{g} / \mathrm{L})$ at site JFSW 10 is an indication of the degradation of the TCE. There was only one detection of a VOC $(2 \mu \mathrm{g} / \mathrm{L}$ of $1,1,2,2-\mathrm{PCA})$ in the pond about $1,500 \mathrm{ft}$ east of the disposal pits, indicating that most of the organic contamination is probably volatilizing from the surface water closer to the disposal area.

Concentrations of aluminum, antimony, arsenic, boron, and nickel in ground water at the toxicmaterials disposal area indicated a local source of contamination. High concentrations of aluminum and antimony were found only in samples from wells in which the $\mathrm{pH}$ exceeded 8.0, which indicates that these concentrations may be the result of increased solubility of colloidal material rather than contamination. Lead was not detected in ground water, although it had been detected at concentrations as high as $87,000 \mu \mathrm{g} / \mathrm{g}$ in soils, indicating that the lead is bound in the soils.

Contaminated ground water from the surficial aquifer is probably discharging close to the edge of the marsh due to the proximity of the disposal pits and the short ground-water-flow paths in the area. Ground water from relatively uncontaminated upgradient areas surrounding the disposal pits would discharge to the marsh farther from the edge, and closer to the relatively uncontaminated ponds farther from the disposal pits. The presence of VC and 1,2-DCE in ground water in the surficial aquifer indicates that natural attenuation of VOC's has occurred within the toxic-materials disposal area. The concentrations of 1,1,2,2-PCA in well JF83 in the surficial aquifer was at 10 percent of its aqueous solubility at ground-water temperature (Montgomery and Welcom, 1990); this high concentration relative to its solubility indicates the presence of DNAPL in the surficial aquifer. 


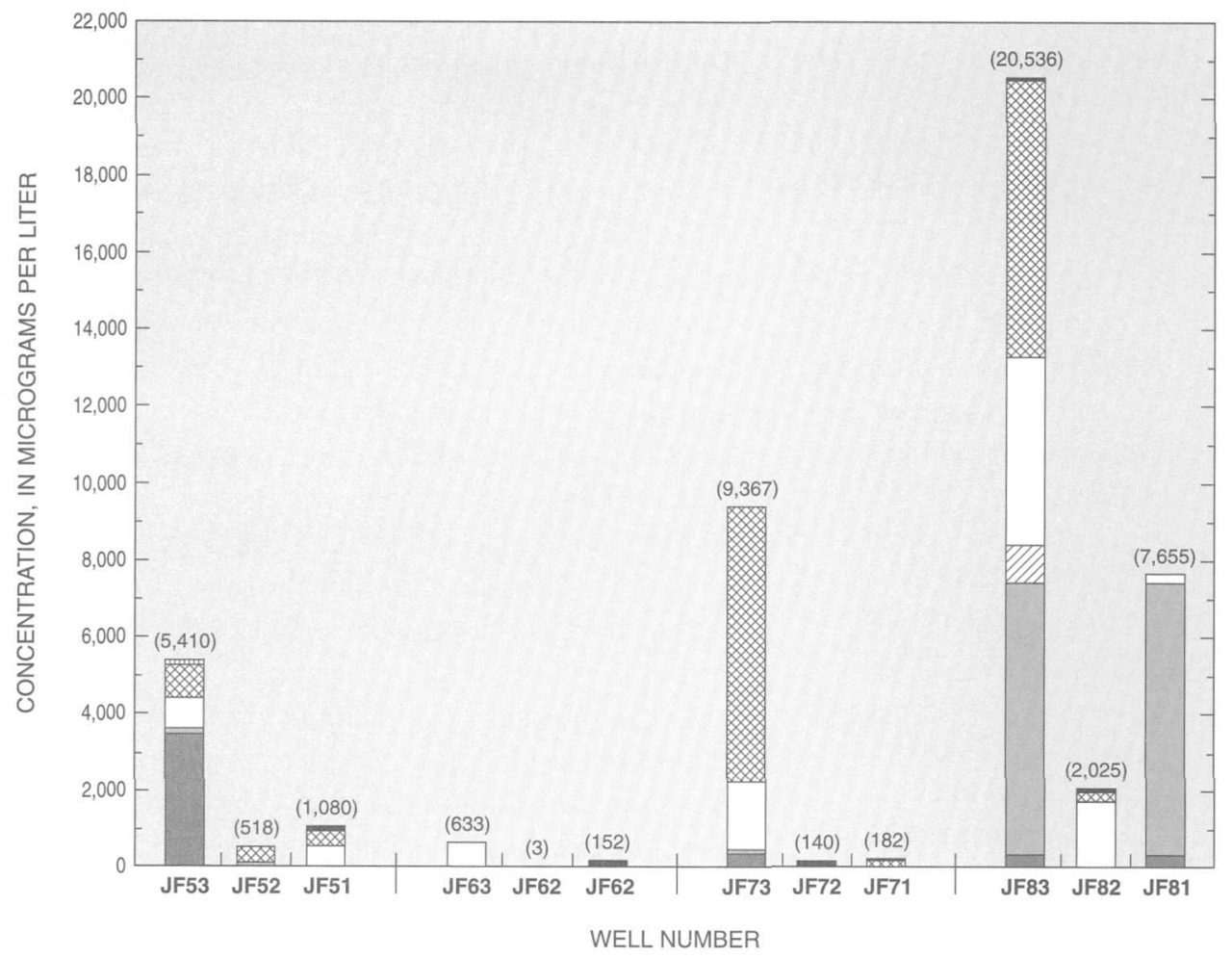

EXPLANATION

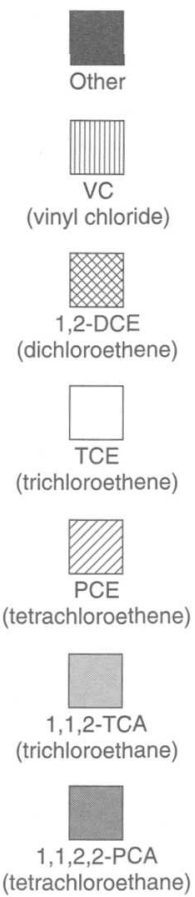

(NOTE: Last digit of well number indicates screened depth of each well, where $1=$ confined aquifer [deepest], $\mathbf{2}$ = confining unit, and $\mathbf{3}=$ surficial aquifer [shallowest].)

Figure 16a. Concentrations of total volatile organic compounds, and the proportions of individual compounds detected in ground water sampled during Phase I at the toxic-materials disposal area, J-Field, Aberdeen Proving Ground, Maryland.

Concentrations of organic compounds detected in the confined aquifer near the disposal pits probably result from introduction of contaminants from the surficial aquifer because of drilling methods. The introduction of organic compounds to the confined aquifer occurred only during the drilling and does not represent a continuing source of contaminants to the aquifer, as evidenced by the significant decrease in concentration of organic compounds between Phase I and Phase II sampling in all wells screened in the confined aquifer.

\section{Assessment of the White-Phosphorus Disposal Area}

The white-phosphorus disposal area was one of the three primary areas used for disposal and testing activities at J-Field. Of the disposal areas discussed in this report, the white-phosphorus disposal area is closest to the Chesapeake Bay, or more specifically, the tidal Gunpowder River. White phosphorus was burned in the pits during testing and disposal activities; however, no records are available concerning the amount and type of all chemicals that were disposed of or burned in the pits. Although disposal activities have been discontinued at the white-phosphorus disposal area since 1980, the site is presently (1997) used as needed to detonate unexploded ordnance that is suspected to contain chemical agents. Sufficient quantities of high explosives are used to destroy the ordnance and any chemical agent that may be present. 


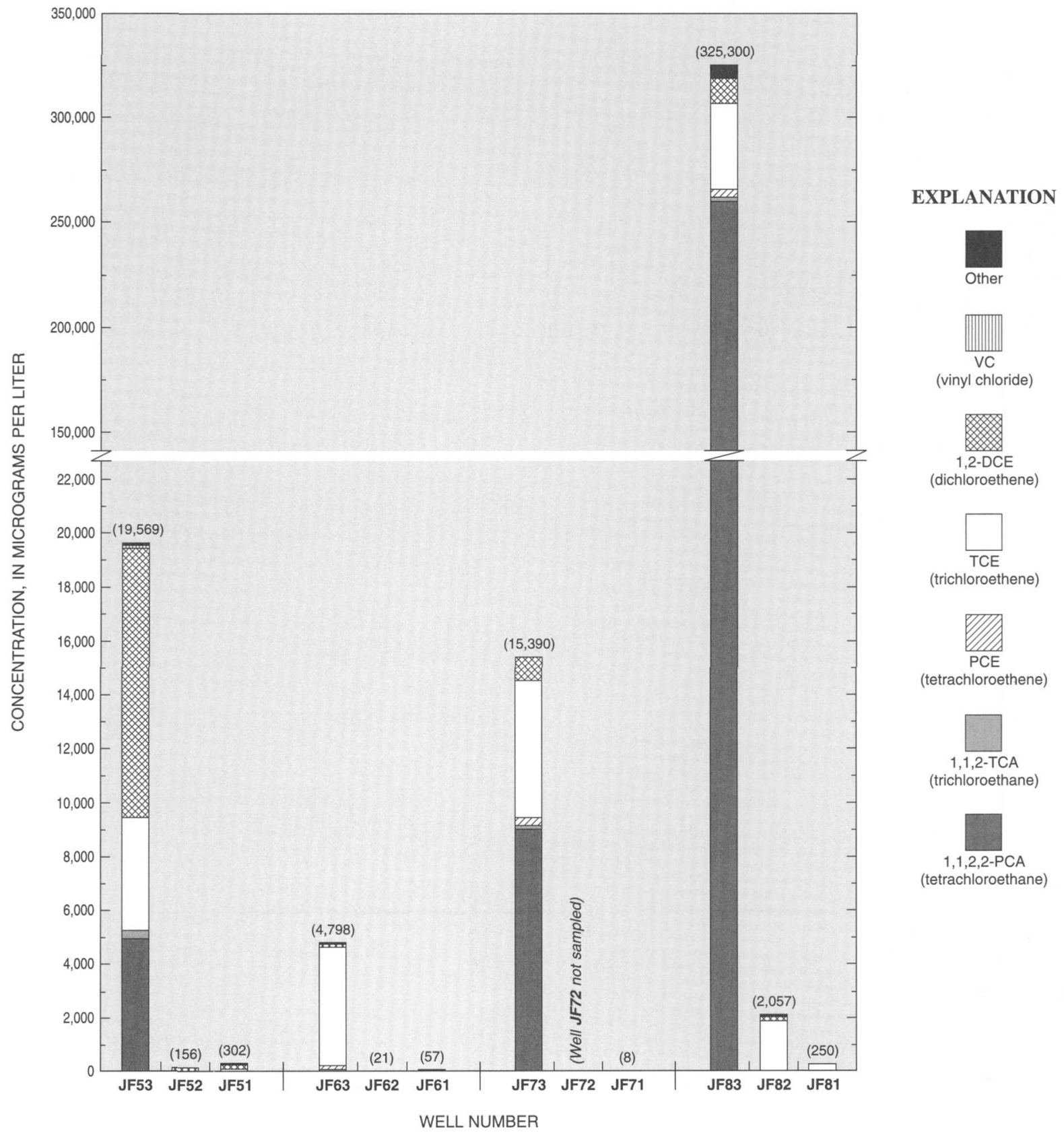

(NOTE: Last digit of well number indicates screened depth of each well, where $\mathbf{1}=$ confined aquifer [deepest], $\mathbf{2}$ = confining unit, and $\mathbf{3}=$ surficial aquifer [shallowest].)

Figure 16b. Concentrations of total volatile organic compounds, and the proportions of individual compounds detected in ground water sampled during Phase II at the toxic-materials disposal area, J-Field, Aberdeen Proving Ground, Maryland. 


\section{Soil Gas}

Thirty-five soil-gas samples were collected by Hughes (1993) at the white-phosphorus disposal area in the summer of 1989. Maps showing the distribution of soil-gas contamination are presented in Hughes (1993), the data are included in Phelan and others (1996), and the distribution of TCE, PCE, benzene, ethylene, toluene, and xylene in soil gas and in ground water in the surficial aquifer is shown in figure 17. Soil-gas flux values indicated contaminant plumes extended northwest and southwest from the disposal pits toward the Gunpowder River.

\section{Soils}

The locations of soil samples where trace metals were detected are shown in figure 17 and the concentrations of these trace metals are shown in table 5. Arsenic, chromium, copper, and lead were detected at most of these sites (table 13). Mercury was detected at a concentration of $0.044 \mu \mathrm{g} / \mathrm{g}$ in a soil sample taken downhill of the disposal pits.

The median concentration of arsenic was $2.5 \mu \mathrm{g} / \mathrm{g}$, which was slightly enriched when compared to average crustal abundances (table 13), but was below the median concentration of $10 \mu \mathrm{g} / \mathrm{g}$ in soils at Carroll Island (fig. 1) across the Gunpowder River from J-Field (Tenbus and Phillips, 1996). Arsenic commonly is found in soils at concentrations of 0.1 to $40 \mu \mathrm{g} / \mathrm{g}$ (Brady, 1974). Median chromium and copper concentrations were not enriched and, therefore, did not indicate contamination for these trace metals.

Lead was detected in seven of nine soil samples at the white-phosphorus disposal area. Median lead concentrations in soils $(17 \mu \mathrm{g} / \mathrm{g})$ were slightly enriched (table 13), but were slightly below the median concentrations of $19.6 \mu \mathrm{g} / \mathrm{g}$ detected in soils at Carroll Island (Tenbus and Phillips, 1996). The range of lead commonly found in soil is 2 to $200 \mu \mathrm{g} / \mathrm{g}$ (Brady, 1974). Concentrations of lead in rain and snow can be as high as $0.1 \mathrm{mg} / \mathrm{L}$ in areas subject to substantial air pollution (Hem, 1985).

Trace-metal concentrations were highest at the white-phosphorus disposal area between the disposal pits and the Gunpowder River. These concentrations were probably due to runoff from the pits; however, concentrations were not significantly above typical background concentra- tions and were within the range of concentrations expected close to a large urban population center, such as Baltimore, Maryland.

Although soil-gas data showed plumes of VOC's in the vicinity of the white-phosphorus disposal area, VOC's were generally not detected in soil samples. $D i-N$-butylphthalate (DNB) was the only organic compound detected in soils at the white-phosphorus disposal area. DNB was detected at a concentration of $4.8 \mu \mathrm{g} / \mathrm{g}$ at site 1 , which is between the disposal pits and the bay. DNB is an insect repellant that is used in impregnating clothing. Given the abundance of mosquitoes and ticks at J-Field, this could have been a remnant of a spray that a worker used at the site either before or during the soil sampling.

\section{Surface Water}

Two surface-water samples were collected in wetlands north (site 3) and south (site 4) of the disposal area during April 1993 (fig. 8), but no samples were taken in the fall of that year because the two sites were dry. Inorganic con-stituents in samples from the two sites are shown in table 8 and organic compounds are shown in table 9. Although runoff from the disposal pits flows directly to the Gunpowder River, runoff from the area surrounding the disposal pits probably reaches the two sites.

\section{Inorganic Constituents}

Magnesium, sodium, potassium, sulfate, and chloride concentrations were higher in water samples at sites 3 and 4 than in samples taken at site 20 in the Chesapeake Bay on the following day (table 8). Concentrations of sodium and chloride in surface-water samples taken at site 3 were approximately nine times the concentrations at site 4 , (table 8 ) indicating that site 3 could be affected by influxes of brackish water during high water in the Gunpowder River and that site 4 is probably a freshwater wetland.

Concentrations of all trace metals except manganese were higher in water from site 3 than site 4 (table 8). Manganese concentrations exceeded the SMCL of $50 \mu \mathrm{g} / \mathrm{L}$ at sites 3 and 4 (table 8). Aluminum concentrations of $1,400 \mu \mathrm{g} / \mathrm{L}$ at site 3 and of $300 \mu \mathrm{g} / \mathrm{L}$ at site 4 were less than the concentration of $2,100 \mu \mathrm{g} / \mathrm{L}$ at site 20 in the bay, and below the maximum concentration detected in 
TCE CONCENTRATIONS IN GROUND WATER,

IN MICROGRAMS PER LITER (PHASE I / PHASE II)

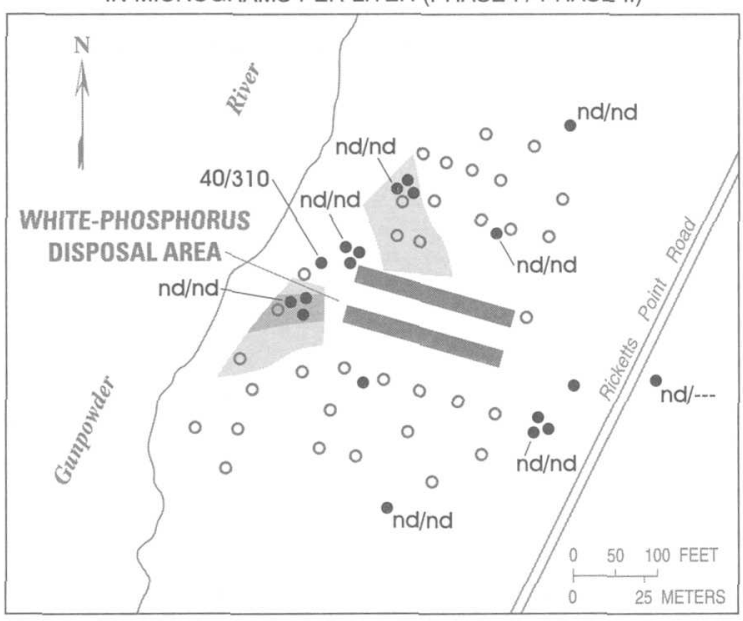

SOIL-GAS CONCENTRATIONS,

TCE RELATIVE-FLUX VALUES

$$
\text { (lon counts) }
$$

GREATER THAN 100,000

$1,000-100,000$

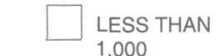

(NOTE: All TCE concentrations in soil samples were below detection limits.)

GENERAL DIRECTIONS OF GROUND-WATER FLOW IN THE SURFICIAL AQUIFER

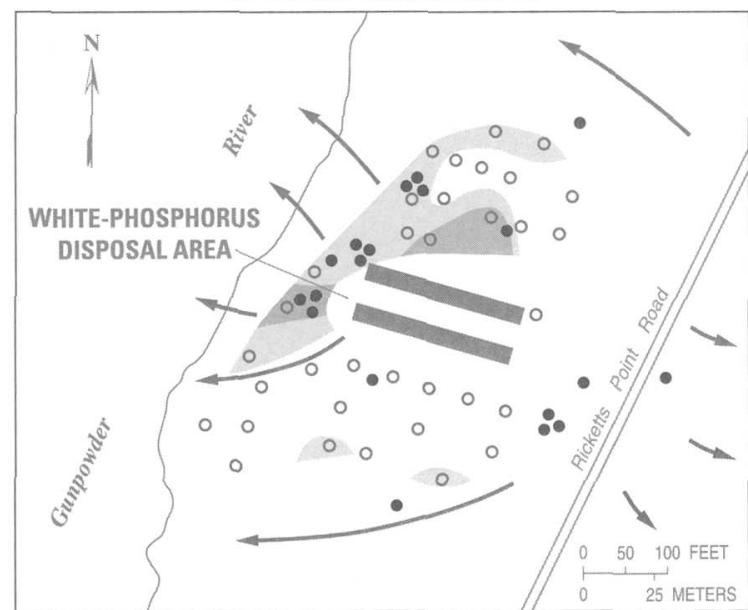

SOIL-GAS CONCENTRATIONS

SIMPLE AROMATIC RELATIVE-FLUX VALUES

$$
\text { (lon counts) }
$$
GREATER THAN $\square$ 10,000-100,000 $\square$ LESS THAN

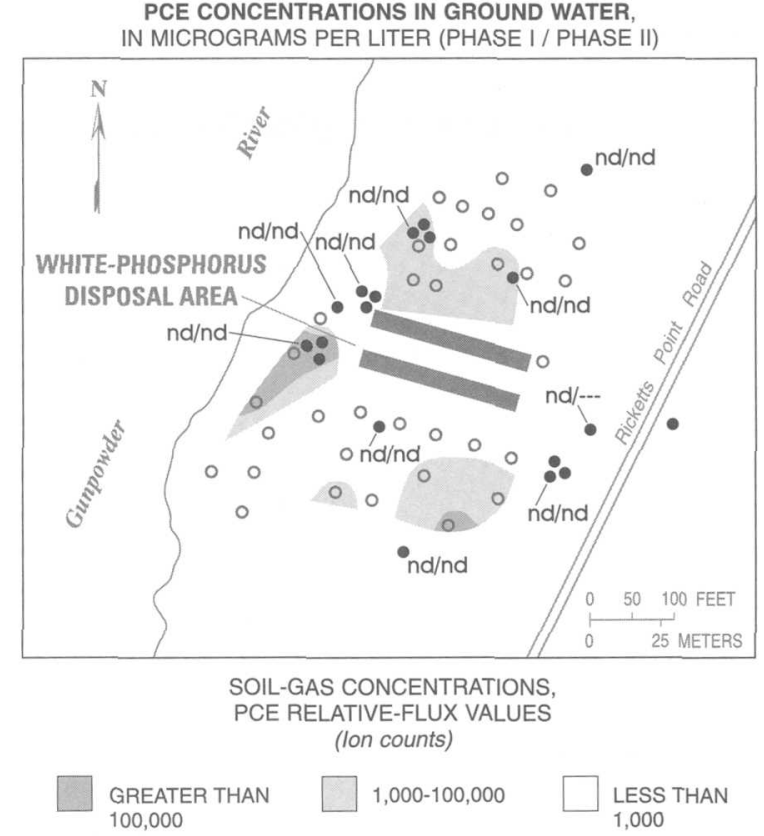

(NOTE: All PCE concentrations in soil samples were below detection limits.)

(NOTE: All concentrations of benzene, toluene, ethylene, and xylene [BTEX] in ground-water and soil samples were below detection limits.)

\section{EXPLANATION}

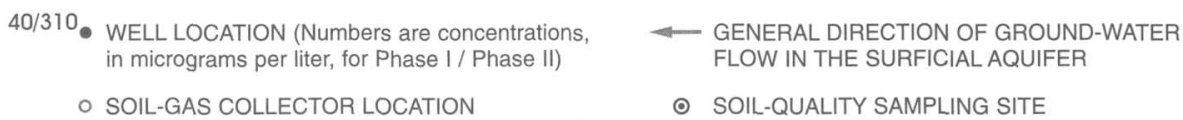

[TCE, trichloroethene; PCE, tetrachloroethene; DBT, di-n-butyl phthalate; $\mathbf{A s}$, arsenic; $\mathbf{C r}$, chromium; $\mathbf{C u}$, copper; $\mathbf{H g}$, mercury; $\mathbf{P b}$, lead; nd, not detected; ---, not analyzed; <, less than]

Figure 17. Results of Phase I soil-gas analyses compared to organic compounds detected in the surficial aquifer during Phase I and II ground-water sampling, directions of ground-water flow in the surficial aquifer, and soil-quality data from the white-phosphorus disposal area, J-Field, Aberdeen Proving Ground, Maryland (modified from Hughes, 1993). 


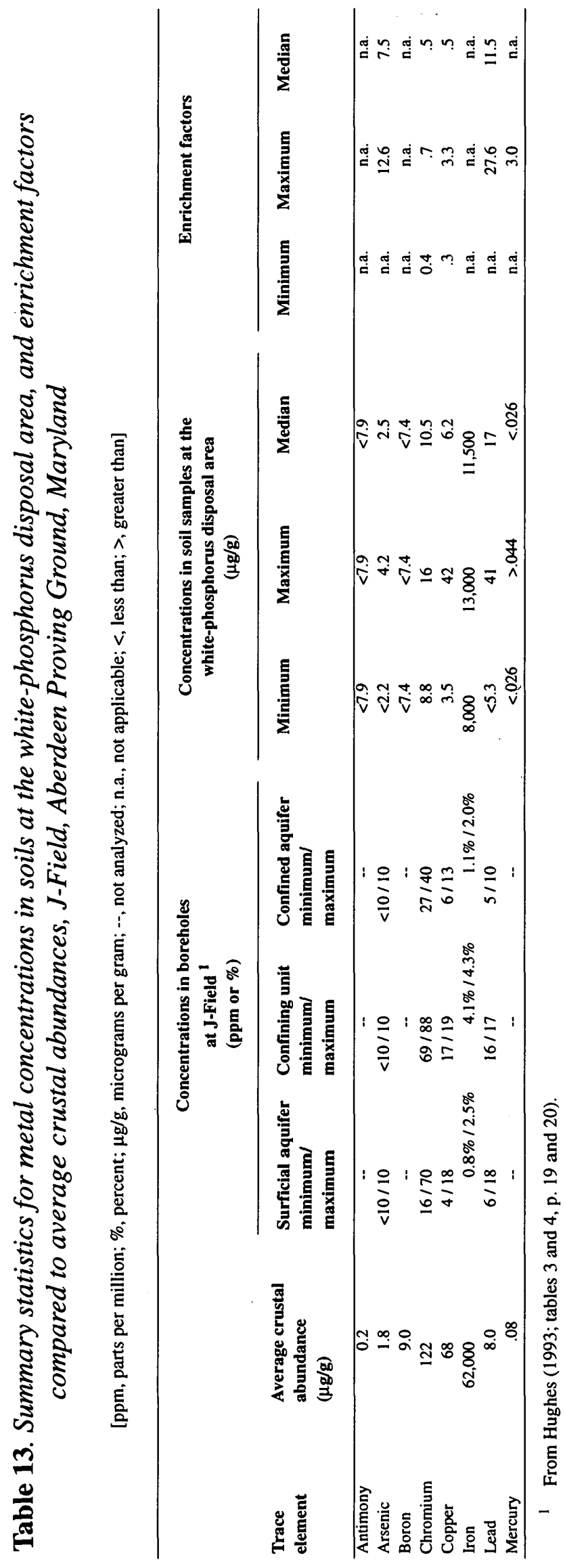


inland surface water at Carroll Island (Tenbus andPhillips, 1996). Concentrations of chromium, cobalt, copper, manganese, vanadium, and zinc at sites 3 and 4 exceeded those at site 20 . The chromium concentration at site 3 was at the minimum reporting limit $(6 \mu \mathrm{g} / \mathrm{L})$, the copper concentration was below the median concentrations of inland surface water at Carroll Island, and concentrations of manganese and zinc were below the maximum concentrations in inland surface water at Carroll Island.

\section{Organic Compounds}

Phenols at a concentration of $20 \mu \mathrm{g} / \mathrm{L}$ at site 4 and 1,2-DCE at a concentration of $1 \mu \mathrm{g} / \mathrm{L}$ at site 3 were detected in surface water at the white-phosphorus disposal area. Phenols can be a degradation product of naturally occurring plant debris and are found in surface water at concentrations usually less than $2 \mu \mathrm{g} / \mathrm{L}$ (Thurman, 1986, p. 146). The high concentration of phenols indicated a possible source of contamination near site 4 . The detection of 1,2-DCE was below the reporting limit of $10 \mu \mathrm{g} / \mathrm{L}$ and, therefore, was an estimated value.

\section{Ground Water}

The direction of ground-water flow and distribution of contaminants in the vicinity of the white-phosphorus disposal pits are shown in figure 17. The contaminant distribution probably results from flow of contaminated ground water from source areas at the pits toward discharge areas in the Gunpowder River (Hughes, 1993).

Seventeen wells in the white-phosphorus disposal pits area were sampled during Phase I sampling, and 13 wells were sampled during Phase II sampling. These wells and the hydrogeologic units they are screened in are listed in the following table, and the well locations are shown in figure 9.

\begin{tabular}{lll}
\hline $\begin{array}{l}\text { Surficial-aquifer } \\
\text { wells }\end{array}$ & $\begin{array}{l}\text { Confining-unit } \\
\text { wells }\end{array}$ & $\begin{array}{l}\text { Confined-aquifer } \\
\text { wells }\end{array}$ \\
\hline JF93 & JF92* & JF91 \\
JF103 & JF102* & JF101 \\
JF113 & JF112* & JF111 \\
JF123 & JF122 & JF121 \\
P5* & & \\
P6 & & \\
P7 & & \\
TH1 & \\
TH3 & \\
* denotes wells sampled only during Phase I; BOLD well numbers denote \\
control wells
\end{tabular}

Well JF103 screened in the surficial aquifer, and wells JF102, JF112, and JF122 in the confining unit had $\mathrm{pH}$ values that exceeded 8.0 , indicating ground-water contamination downgradient of the disposal pits. Possible explanations for these high $\mathrm{pH}$ values were the addition of hydroxides during disposal activities, and grout contamination that may have occurred during well installation. These possibilities were further investigated in the previous discussion of "Field Parameters" in the "Assessment of the Toxic-Materials Disposal Area" section.

Grout contamination could be indicated in well JF103 on the basis of the following: (1) $\mathrm{pH}$ values were 12.5 in Phase I and 12.8 in Phase II; (2) the potassium concentration of $45 \mathrm{mg} / \mathrm{L}$ in Phase I was 25 times the median potassium concentration from samples in background wells in the surficial aquifer; (3) the bicarbonate concentration of $1,040 \mathrm{mg} / \mathrm{L}$ in Phase I was 130 times the median bicarbonate concentration in background wells in the surficial aquifer; and (4) the magnesium concentration was below the reporting limit of $0.13 \mathrm{mg} / \mathrm{L}$, which is less than the median concentration of $3.7 \mathrm{mg} / \mathrm{L}$ in control wells in the surficial aquifer. The relation among these concentrations is similar to grout contamination documented by Lorah and Vroblesky (1989, p. 41). During Phase II sampling, the potassium concentration from well JF103 was lower $(18 \mathrm{mg} / \mathrm{L})$, and the magnesium concentration was higher $(0.19 \mathrm{mg} / \mathrm{L})$ than in Phase $\mathrm{I}$, indicating a possible dilution of grout contamination, but the $\mathrm{pH}$ remained 12.8. The bicarbonate concentration was not available. It is possible that these same effects could have been caused by the addition of sodium or potassium hydroxides or other chemicals during the disposal activities in the pits immediately upgradient of the well, but samples from nearby wells in the surficial aquifer do not have the same chemical characteristics as samples from well JF103.

Wells JF102, JF112, and JF122, which are screened in the confining unit with $\mathrm{pH}$ values greater than 8.0, did not have correspondingly high concentrations of bicarbonate that would have indicated grout contamination. Therefore, the high $\mathrm{pH}$ values at these wells were probably caused by disposal activities at the pits. 
The median specific-conductance value was $233 \mu \mathrm{S} / \mathrm{cm}$ in ground-water samples from the surficial aquifer at the white-phosphorus disposal area during Phase I. This was slightly higher than the median value of $183 \mu \mathrm{S} / \mathrm{cm}$ from control wells sampled in Phase I. By comparison, the median specific conductance for the surficial aquifer at Carroll Island was $345 \mu \mathrm{S} / \mathrm{cm}$ (Tenbus and Phillips, 1996). The specific conductance for well JF103 (in which grout contamination is suspected) was 3,830 and $3,990 \mu \mathrm{S} / \mathrm{cm}$ in Phases I and II, respectively. The specific conductance was $448 \mu \mathrm{S} / \mathrm{cm}$ in the upgradient well JF92 in the confining unit in Phase I (the well was not sampled during Phase II). JF102, JF112, and JF122, which also are screened in the confining unit, had specific conductance values exceeding $2,000 \mu \mathrm{S} / \mathrm{cm}$ during Phase I. Of these three wells, only well JF122 was resampled during Phase II, and the specific conductance decreased from $2,710 \mu \mathrm{S} / \mathrm{cm}$ to $410 \mu \mathrm{S} / \mathrm{cm}$. This indicates that although well JF122 is downgradient of the disposal pits, the water quality is improving with time.

In Phase I samples from the surficial aquifer, dissolved oxygen concentrations were greater than $6.0 \mathrm{mg} / \mathrm{L}$ in samples from wells upgradient of the disposal pits and less than $0.4 \mathrm{mg} / \mathrm{L}$ in all wells downgradient of the pits. This decrease in dissolved oxygen concentration from upgradient wells to downgradient wells is probably caused by reactions with naturally occurring oxidizable material in the aquifer. During Phase II, dissolved oxygen concentrations in upgradient wells ranged from 1.0 to $6.0 \mathrm{mg} / \mathrm{L}$, and concentrations in downgradient wells ranged from 0.9 to $1.5 \mathrm{mg} / \mathrm{L}$. Dissolved oxygen concentrations in wells screened in the confining unit and confined aquifer were less than $1.3 \mathrm{mg} / \mathrm{L}$ in both Phase I and II samples.

The median alkalinity values in the surficial aquifer during Phase I and Phase II were 52 and $45 \mathrm{mg} / \mathrm{L}$, respectively. Both these values were higher than the median concentration of $8 \mathrm{mg} / \mathrm{L}$ in samples from control wells in the surficial aquifer. In comparison, the median alkalinity value in the surficial aquifer at Carroll Island was $35 \mathrm{mg} / \mathrm{L}$ (Tenbus and Phillips, 1996). Alkalinity values ranged from 200 to $670 \mathrm{mg} / \mathrm{L}$ in the confining-unit wells, and from 150 to $250 \mathrm{mg} / \mathrm{L}$ in the confinedaquifer wells during Phase I and II.

\section{Inorganic Constituents}

Trace metals detected in ground water at the white-phosphorus disposal area during Phase I sampling included aluminum, antimony, arsenic, barium, lead, and nickel; however, only the concentrations of aluminum, antimony, and lead exceeded MCL's. Concentrations of dissolved metals detected in Phase I sampling, with the exception of barium, are shown in table 14. Phase I samples are presented because fewer wells were sampled and fewer metals were analyzed during Phase II sampling. Arsenic at a concentration of $21 \mu \mathrm{g} / \mathrm{L}$, which is about 40 percent of the MCL $(50 \mu \mathrm{g} / \mathrm{L})$, was detected in well P7 in the surficial aquifer between the disposal pits and the Gunpowder River. Barium was detected in all wells at J-Field at concentrations generally less than 10 percent of the MCL of $2,000 \mu \mathrm{g} / \mathrm{L}$ and is, therefore, not a contaminant of concern. Cobalt was not analyzed in samples from these wells taken during Phase I, or from soil samples taken at J-Field. During Phase II sampling, cobalt was detected in wells P7, P8, TH1, and JF93 in the surficial aquifer at concentrations of $97,28,11$, and $22 \mu \mathrm{g} / \mathrm{L}$, respectively. Cobalt also was detected at a concentration of $10 \mu \mathrm{g} / \mathrm{L}$ in surface water at site 3. Uncontaminated natural water should contain no more than a few micrograms per liter of cobalt (Hem, 1985). The relatively high cobalt concentrations in ground water and surface water indicate a local contamination source at the whitephosphorus disposal area. 
Table 14. Dissolved trace metals detected in ground water at the white-phosphorus disposal area during Phase I sampling, May-June, 1990, J-Field, Aberdeen Proving Ground, Maryland

[All concentrations are in micrograms per liter $(\mu \mathrm{g} / \mathrm{L})$. BOLD numbers indicate concentrations that exceed SMCL's or MCL's; * indicates wells with $\mathrm{pH}$ higher than 8 ; No., number; $<$, less than; --, data not available]

$\begin{array}{llll}\text { Surf. aq., surficial aquifer } & \mathrm{Al} \text {, aluminum } & \mathrm{Pb} \text {, lead } & \mathrm{SMCL} \text {, secondary maximum contaminant levels } \\ \text { Conf. unit, confining unit } & \mathrm{Sb} \text {, antimony } & \mathrm{Ni} \text {, nickel } & \mathrm{MCL} \text {, maximum contaminant levels } \\ \text { Conf. aq., confined aquifer } & \mathrm{As} \text {, arsenic } & \mathrm{Zn} \text {, zinc] } & \end{array}$

\begin{tabular}{|c|c|c|c|c|c|c|c|}
\hline $\begin{array}{l}\text { Well } \\
\text { No. }\end{array}$ & $\begin{array}{l}\text { Hydrologic } \\
\text { unit }\end{array}$ & $\mathrm{Al}^{1}$ & $\mathbf{S b}^{2}$ & $\mathbf{A s}^{3}$ & $\mathbf{P b}^{4}$ & $\mathrm{Ni}^{5}$ & $\mathrm{Zn}^{6}$ \\
\hline P5 & Surf. aq. & $<110$ & $<60$ & $<2$ & $<4$ & $<32$ & 21 \\
\hline P6 & Surf. aq. & $<110$ & $<60$ & $<2$ & $<4$ & $<32$ & 29 \\
\hline P7 & Surf. aq. & 240 & $<60$ & 21 & $<4$ & 40 & 87 \\
\hline P8 & Surf. aq. & 780 & $<60$ & $<2$ & $<4$ & 39 & 100 \\
\hline THI & Surf. aq. & 170 & $<60$ & $<2$ & 120 & $<32$ & 60 \\
\hline JF93 & Surf. aq. & $<110$ & $<60$ & $<2$ & $<4$ & 55 & 170 \\
\hline JFI03* & Surf. aq. & 1,600 & 63 & $<2$ & $<4$ & $<32$ & 39 \\
\hline JF113 & Surf. aq. & $<110$ & $<60$ & $<2$ & $<4$ & $<32$ & 33 \\
\hline $\mathrm{JF} 123$ & Surf. aq. & $<110$ & $<60$ & $<2$ & $<43$ & $<32$ & 60 \\
\hline JF92 & Conf. unit & $<110$ & $<60$ & $<2$ & $<4$ & $<32$ & 36 \\
\hline JF102* & Conf. unit & 420 & $<60$ & $<2$ & $<4$ & $<32$ & $<18$ \\
\hline JF112* & Conf. unit & $<110$ & 82 & $<2$ & $<43$ & $<32$ & $<18$ \\
\hline JF91 & Conf. aq. & $<110$ & $<60$ & $<2$ & $<4$ & $<32$ & 33 \\
\hline JF101 & Conf. aq. & $<110$ & $<60$ & 3 & $<4$ & $<32$ & $<18$ \\
\hline JF111 & Conf. aq. & $<110$ & $<60$ & 3 & $-\cdot$ & $<32$ & $<18$ \\
\hline \multicolumn{8}{|c|}{ SMCL equals $200 \mu \mathrm{g} / \mathrm{L}$. } \\
\hline 2 & \multicolumn{7}{|l|}{ MCL equals $6 \mu \mathrm{g} / \mathrm{L}$. } \\
\hline 3 & \multicolumn{7}{|l|}{ MCL equals $50 \mu \mathrm{g} / \mathrm{L}$. } \\
\hline 4 & \multicolumn{7}{|l|}{ MCL equals $15 \mu \mathrm{g} / \mathrm{L}$. } \\
\hline 5 & \multicolumn{7}{|l|}{ MCL equals $100 \mu \mathrm{g} / \mathrm{L}$} \\
\hline 6 & \multicolumn{7}{|l|}{ SMCL equals $5,000 \mu \mathrm{g} / \mathrm{L}$. } \\
\hline
\end{tabular}

Because the ground-water samples for dissolved constituents were filtered through a 0.45 -micron filter rather than a 0.1 -micron filter, some particulate aluminum could have remained in the sample, which could have increased the dissolved aluminum concentration. The high aluminum concentration is, therefore, most likely not a result of contamination. The aluminum concentration in well P7 was $240 \mu \mathrm{g} / \mathrm{L}$ and $780 \mu \mathrm{g} / \mathrm{L}$ in well P8; both concentrations exceeded the SMCL of $200 \mu \mathrm{g} / \mathrm{L}$.
Lead was detected during Phase I sampling in well $\mathrm{TH} 1$ at a concentration of $120 \mu \mathrm{g} / \mathrm{L}$, which is about eight times the MCL. TH1 was the only well at J-Field that had detectable concentrations of lead. The well is screened in the surficial aquifer and is located north of the disposal pits, downgradient of an area where lead was detected in soil samples. None of the Phase II ground-water samples were analyzed for lead. 
Table 15. Organic compounds detected in ground water during Phase I ${ }^{1}$ and II $^{2}$ sampling at the white-phosphorus disposal area, J-Field, Aberdeen Proving Ground, Maryland [Units are in micrograms per liter; Bold numbers indicate concentrations above reporting limits; RDX, cyclotrimethylene
trinitramine; No., number; * indicates well with pH greater than $8.0 ;<$, less than; -- , data not available; MCL, maximum
contaminant level]

\begin{tabular}{|c|c|c|c|c|c|c|}
\hline $\begin{array}{l}\text { Well } \\
\text { No. }\end{array}$ & $\begin{array}{l}\text { Hydrologic } \\
\text { unit }\end{array}$ & $\begin{array}{l}\text { Chloromethane, } \\
\text { Phase I / II }{ }^{3}\end{array}$ & $\begin{array}{l}\text { Trichloroethene, } \\
\text { Phase I / II }{ }^{4}\end{array}$ & $\begin{array}{l}\text { 2,6 Di-nitrotoluene, } \\
\text { Phase I/ II }\end{array}$ & $\begin{array}{l}\text { RDX, } \\
\text { Phase I / II }{ }^{3}\end{array}$ & $\begin{array}{l}\text { Cyanide, } \\
\text { Phase I/ II } 5\end{array}$ \\
\hline P6 & Surficial aquifer & $<1.2 /<10$ & $<1 /<10$ & $<0.6 /<2$ & $<0.4 /<2$ & $7 / \ldots$ \\
\hline P7 & Surficial aquifer & $2.8 /<33$ & $40 / 310$ & $-\quad /<2$ &.$- / 4.7$ & $<5 / \ldots$ \\
\hline $\mathrm{JF} 113$ & Surficial aquifer & $<1.2 /<10$ & $<1 /<10$ & $<0.6 /<2$ & $<.4 / 5.4$ & $<5 / \ldots$ \\
\hline $\mathrm{JF} 122 *$ & Confining unit & $<1.2 /<10$ & $<1 /<10$ & $2.26 /<2$ & $1.07 /<2$ & $9 / .$. \\
\hline
\end{tabular}

1 Phase I is from May to June, 1990.

2 Phase II is from November 1992 to January 1993.

3 No MCL available.

$4 \mathrm{MCL}$ equals $5 \mu \mathrm{g} / \mathrm{L}$.

5 MCL equals $200 \mu \mathrm{g} / \mathrm{L}$.

\section{Organic Compounds}

Detections of organic compounds in ground water at the white-phosphorus pits during Phase I and II sampling are shown in table 15. The concentrations of TCE in well P7 greatly exceeded the MCL in both Phase I and Phase II. Chloromethane, TCE (at concentrations exceeding the $\mathrm{MCL}), 2,6$ di-nitrotoluene, cyclotrimethylene trinitramine (RDX), and cyanide were detected during Phase I sampling; however, TCE (at concentrations exceeding the MCL) and RDX were the only compounds detected during Phase II sampling. RDX, which is an explosive compound, was detected at concentrations of less than $2 \mu \mathrm{g} / \mathrm{L}$ in samples from wells P9 and JF103 in the surficial aquifer, and in well JF122 in the confining unit.

TCE was only detected in well P7 in the surficial aquifer. Concentrations of TCE in this well, which is located between the disposal pits and the Gunpowder River, increased from $40 \mu \mathrm{g} / \mathrm{L}$ in Phase I to $310 \mu \mathrm{g} / \mathrm{L}$ in Phase II (fig. 17). TCE was not detected in any soil samples at the whitephosphorus disposal area. The extent and relative concentrations of TCE mapped using the soil-gas data do not correlate with the soil- and ground- water-quality data from the white-phosphorus disposal area (fig. 17). The soil-gas measurements indicated a larger area of TCE contamination than that determined using the ground-water and soilquality data. No TCE was detected in samples from wells screened in the confining unit or confined aquifer.

\section{Contamination at the White-Phosphorus Disposal Area}

Soil, surface-water, and ground-water contamination at the white-phosphorus disposal area was localized rather than widespread. The major contaminants were TCE and lead. TCE was detected at a concentration of $40 \mu \mathrm{g} / \mathrm{L}$ in Phase I and $310 \mu \mathrm{g} / \mathrm{L}$ in Phase II in well P7. Lead was detected at a concentration of $120 \mu \mathrm{g} / \mathrm{L}$ in Phase I at well TH1.

Arsenic, chromium, copper, and lead were detected at most soil-sampling sites at the whitephosphorus disposal area at concentrations typical of background levels. Arsenic and lead concentrations in the soil were slightly enriched at site JS1, which is proximal and downgradient of the north pit. Mercury was detected in one soil sample $(0.044 \mu \mathrm{g} / \mathrm{g})$ downhill of the disposal pits. A single detection in soils of $d i$ - $n$-butyl phthalate 
(table 7) is probably from an insect repellant used at the site prior to or during sampling rather than an indicator of contamination.

Trace-metal concentrations in soils were highest at the site between the disposal pits and the Gunpowder River. These concentrations were probably due to runoff from the pits; however, concentrations were not significantly above typical background concentrations and were within the range of concentrations expected close to a large urban population center, such as Baltimore, Maryland.

Surface-water samples were collected in marshes to the north and south of the disposal pits, which were not directly downgradient of the pits but were downgradient of the area surrounding the pits. Samples only were collected in the spring of 1993 because the sites were dry during the fall of 1993 sampling effort. Concentrations of inorganic constituents were generally nine times higher at site 3 than at site 4, and concentrations of many trace metals (except aluminum) were higher at sites 3 and 4 than in the Bay at site 20. Inorganic surface-water quality at sites 3 and 4 was similar to the surface-water quality at inland sites at Carroll Island, which is across the Gunpowder River. The phenol concentration of $20 \mu \mathrm{g} / \mathrm{L}$ at site 4 could be the result of degradation of naturally occurring plant debris, and/or contamination at the site.

Ground-water samples from well JF103 screened in the surficial aquifer and from wells $\mathrm{JF} 102$, JF112, and JF122 in the confining unit had $\mathrm{pH}$ values that exceeded 8.0. The high $\mathrm{pH}$ in well JF103 is probably due to grout contamination because of well construction methods. The wells in the confining unit were probably contaminated by alkali from disposal operations rather than affected by grout contamination.

Lead was detected during Phase I sampling in well $\mathrm{TH} 1$ at a concentration of $120 \mu \mathrm{g} / \mathrm{L}$, which is about eight times the MCL. TH1 was the only well at J-Field with detectable concentrations of lead. This well is screened in the surficial aquifer and is north of the disposal pits, downgradient of an area where lead was detected in soil samples. None of the Phase II ground-water samples were analyzed for lead.
Five organic compounds were detected in ground water at the white-phosphorus disposal area during Phase I sampling, and only two organic compounds were detected during Phase II sampling. The MCL for TCE $(5 \mu \mathrm{g} / \mathrm{L})$ was greatly exceeded in both Phase I and Phase II. TCE was the only compound detected in the same well (P7) in both Phase I and II, and was detected at concentrations of 40 and $310 \mu \mathrm{g} / \mathrm{L}$, respectively, both of which exceeded the MCL. No PCE or simple aromatic compounds were detected in ground water in either the surficial aquifer, confining unit, or confined aquifer, or in soils at the whitephosphorus disposal area. No plumes of organic compounds were found in the ground water near the white-phosphorus disposal area. The few detections were sporadically distributed. The results of the 1991 soil sampling and the 1990 and 1992-93 ground-water sampling did not correlate well with the results of the soil-gas sampling performed in 1989 at the white-phosphorus disposal area.

\section{Assessment of the Riot-Control-Agent Disposal Area}

The riot-control-agent disposal area was one of the three primary areas used for disposal and testing activities at J-Field. Riot-control agents were disposed of in pits from about 1940 to 1980, with open-pit burning and detonation as the primary disposal methods (Hughes, 1993). Disposal activities at this site ceased in 1980 and no other chemical-agent testing has been done since then. Water that collects in the pit at the riot-controlagent disposal area drains into the Gunpowder River near Ricketts Point (fig. 2). The area is presently (1997) overgrown with trees and brush.

\section{Soil Gas}

Twelve soil-gas samples were collected by Hughes (1993) at the riot-control-agent disposal area during May 1990. The soil-gas contaminant plumes mapped by Hughes (1993) indicated contamination north and south of the disposal pits. Maps showing the distribution of soil-gas contamination are presented in Hughes (1993), and the data are included in Phelan and others (1996). The distribution of DCE plus TCA, and TCE plus PCE 


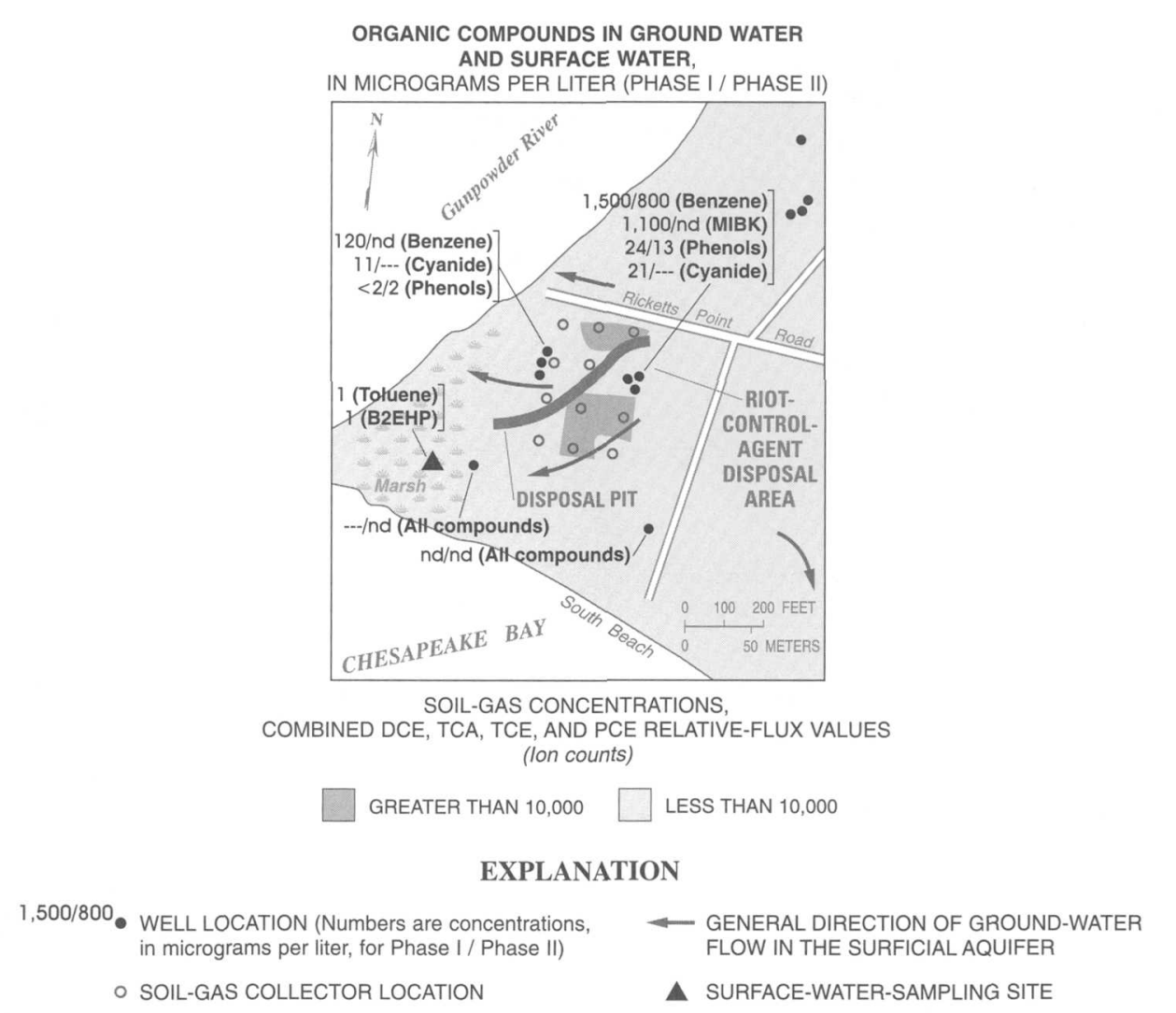

[B2EHP, bis 2-ethylhexyl phthalate; DBT, di-n-butyl phthalate; DCE, dichloroethene; MIBK, methylisobutylketone; PCE, tetrachloroethene; TCA, trichloroethane; TCE, trichloroethene; nd, not detected; ---, not analyzed]

Figure 18. Results of Phase I soil-gas analyses compared to organic compounds detected in the surficial aquifer during Phase I and II ground-water sampling and in the spring 1993 surface-water sampling, and the directions of ground-water flow in the surficial aquifer at the riot-control-agent disposal area, J-Field, Aberdeen Proving Ground, Maryland (modified from Hughes, 1993).

in soil-gas samples is compared with concentrations of contaminants in soil, surface water, and ground water in figure 18. Because no soil, surface-water, and ground-water samples were collected from within the mapped area of the soilgas plumes, it is not possible to confirm the mapped extent of the contaminant plumes.

\section{Soils}

The locations of soil sampling sites and the concentrations of trace metals detected at the riotcontrol-agent disposal area are shown in figure 19. Arsenic, chromium, copper, lead, mercury, and zinc were detected in most samples near the disposal pits; however, cadmium at a concentration of $0.8 \mu \mathrm{g} / \mathrm{g}$ was detected in only one of these samples (fig. 19). Enrichment factors were calculated for selected trace metals and the minimums, medians, and maximums are listed in table 16. Lead had a median enrichment factor of 30.3 , indicating prevalent contamination by this metal. Cadmium had a maximum enrichment factor of 38 , which represents localized contamination by this metal at the site that is presently (1997) at the edge of South Beach (fig 19). Concentrations of lead and cadmium were found in residue from burning smoke mixtures and pyrotechnic testing (Nemeth, 1989); these activities are the probable sources of lead and cadmium detected in soils at this site during the current study.

Acetone, benzoic acid, and benzyl-butylphthalate were the only organic compounds detected in soils at the riot-control-agent disposal area. On the basis of quality-assurance data in Phelan and others (1996), acetone was probably introduced during sampling or laboratory handling, was not representative of field samples, and has, therefore, not been included in table 7. Benzoic 


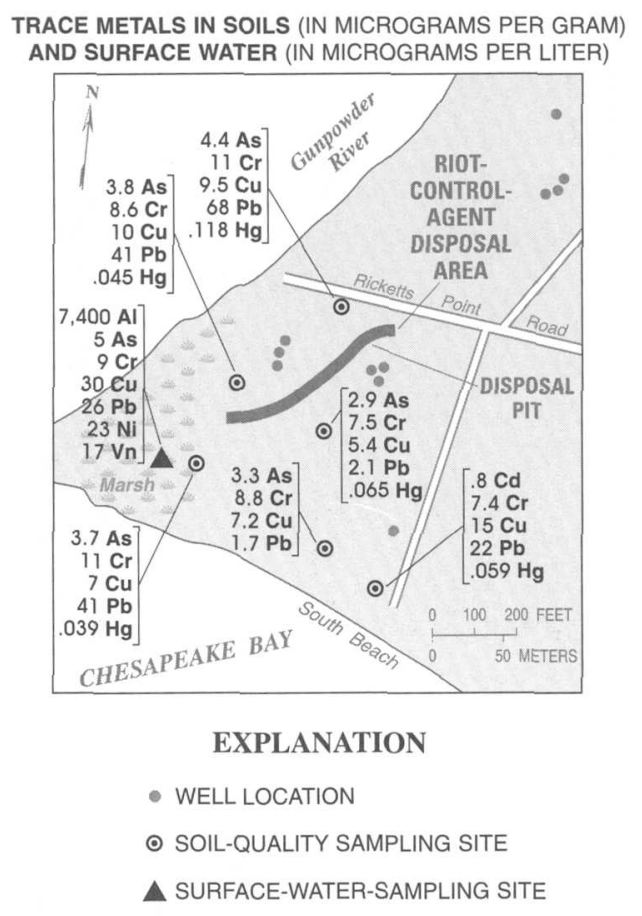

[Al, aluminum; As, arsenic; Cd, cadmium; Cr, chromium; Cu, copper; Hg, mercury; Ni, nickel; Pb, lead; Vn, vanadium]

[Trace-metal concentrations in soil are in micrograms per gram, and samples were collected in April 1991 Trace-metal concentrations in surface water are in micrograms per liter, and samples were collected in April 1993.]

(NOTE: Trace-metal concentrations in ground-water samples did not exceed concentrations found in control wells.)

Figure 19. Concentrations of trace metals in soils and surface-water samples at the riot-control-agent disposal area, J-Field, Aberdeen Proving Ground, Maryland.

acid is a naturally occurring compound that was detected in many soil samples at J-Field. Benzylbutylphthalate was detected at low levels $(0.6 \mu \mathrm{g} / \mathrm{g}$ or less $)$ in seven samples at J-Field, but was not detected in the corresponding duplicate samples; therefore, the detections are questionable.

\section{Surface Water}

One surface-water sample was collected at the riot-control-agent disposal area at site JFSW5 during April 1993 (fig. 8), but no samples were taken in the fall of that year because the site was dry. The site is located in wetlands southwest of and downhill from the disposal pit and is not near either of the soil-gas plumes mapped by Hughes (1993). Surface-water runoff from the area discharges directly to the Gunpowder River.
Inorganic water-quality data from the site are shown in table 8 . Organic water-quality data are shown in table 9.

\section{Inorganic Constituents}

Concentrations of total (dissolved and suspended) trace metals detected at site JFSW5 and in soils in the area are shown in figure 19.

Arsenic, chromium, copper, and lead were detected at site JFSW5 and in nearly all soil samples in the riot-control-agent disposal area. The lead concentration of $26 \mu \mathrm{g} / \mathrm{L}$ at site JFSW5 was the second highest concentration measured in surface water at $\mathrm{J}$-Field $(51 \mu \mathrm{g} / \mathrm{L}$ was measured at site JFSW7), and was almost twice the MCL for lead $(15 \mu \mathrm{g} / \mathrm{L})$. Aluminum at a concentration of $7,400 \mu \mathrm{g} / \mathrm{L}$ was detected at site JFSW5 and was probably present in colloidal form. Aluminum concentrations in surface water at Carroll Island (fig. 1) ranged from 


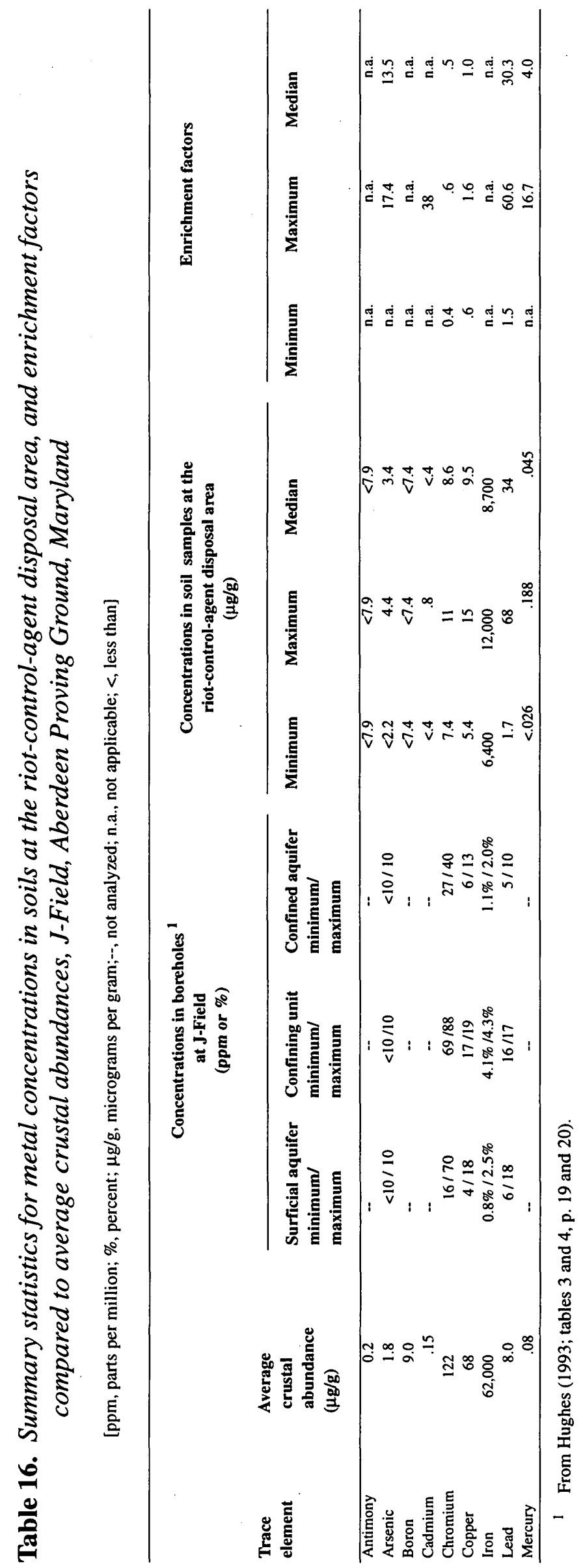


less than 141 to $2,300 \mu \mathrm{g} / \mathrm{L}$, with a median of $400 \mu \mathrm{g} / \mathrm{L}$ (Tenbus and Phillips, 1996).

\section{Organic Compounds}

Toluene and bis 2-ethyl-hexyl phthalate were the only organic compounds detected at site JFSW5 (fig. 18). The concentrations of each of these compounds were $1 \mu \mathrm{g} / \mathrm{L}$, which is an estimated value because it is below the reporting limit of $10 \mu \mathrm{g} / \mathrm{L}$. On the basis of these results, minimal organic contamination of inland surface water has resulted downgradient of the riotcontrol-agent disposal area.

\section{Ground Water}

Eight wells are located near the riot-controlagent disposal area (figs. 9 and 18). These wells and the aquifers that the wells are screened in are listed in the following table. All wells except JF143, which was drilled after the completion of Phase I ground-water sampling, were sampled during both Phase I and Phase II ground-water sampling.

\begin{tabular}{lll}
\hline $\begin{array}{l}\text { Surficial-aquifer } \\
\text { wells }\end{array}$ & $\begin{array}{l}\text { Confining-unit } \\
\text { wells }\end{array}$ & $\begin{array}{l}\text { Confined-aquifer } \\
\text { wells }\end{array}$ \\
\hline JF13 & JF12 & JF11 \\
JF23 & JF22 & JF21 \\
JF143** & \\
TH10 & \\
** denotes wells sampled only during Phase II; BOLD well \\
numbers denote control wells
\end{tabular}

Ground-water samples from wells near the riotcontrol-agent disposal area did not have high $\mathrm{pH}$ values similar to those observed in some wells at the toxic-materials disposal area and the whitephosphorus disposal area. The sample from well JF143 had a pH of 3.7 during Phase II, which was below the range of background $\mathrm{pH}$ values for J-Field (table 3).

\section{Inorganic Constituents}

Well TH10 is the only control well screened in the surficial aquifer near the riot-control-agent disposal area, and is near South Beach. The shoreline has receded closer to well TH10 over time, exposing the area near the well to the possible effects of brackish-water intrusion. The well is presently (1997) about $50 \mathrm{ft}$ from the beach. Specific conductance and chloride concentrations in water samples from well TH10 increased 29 and 25 percent, respectively, between Phase I and Phase II sampling. In contrast, specific conductance values for wells JF13 and JF23 did not increase between Phase I and II sampling.

All inorganic constituents in ground-water samples from wells in the surficial aquifer at the riot-control-agent disposal area showed increases of calcium, potassium, sulfate, and chloride in comparison to concentrations at the ground-water control wells. Incineration of the nerve agent VX and mustard agents can produce sulfate as a degradation product and this may be the source of the increased sulfate concentrations. Concentrations of major ions were generally higher in the down-gradient wells JF22 and JF21 in the confining unit and confined aquifer, respectively, than in the upgradient wells JF12 and JF11. Trace metal concentrations in ground water did not exceed those in the ground-water control wells in the surficial aquifer, confining unit, and confined aquifer. Cadmium, chromium, copper, lead, and mercury were not detected in any ground-water samples in the riot-control-agent disposal area.

\section{Organic Compounds}

Concentrations of organic compounds detected in the surficial aquifer during Phase I and II sampling are shown in figure 18 . Benzene and cyanide were both detected in Phase I samples from wells screened in the surficial aquifer that were located upgradient and downgradient of the disposal pit in the riot-control-agent disposal area. A potential source of benzene is from the breakdown of the tear agent bromobenzylcyanide, which may have been disposed of at this site. Benzene in ground water can further degrade to carbon dioxide and water under either aerobic or anaerobic conditions (Chapelle, 1993). Benzene concentrations in water samples from the surficial aquifer declined between Phase I and Phase II sampling, and dissolved oxygen concentrations increased. In the downgradient well JF23, benzene concentrations declined from $120 \mu \mathrm{g} / \mathrm{L}$ in the Phase I samples to below the detection limit in the Phase II samples, and dissolved oxygen concentrations increased from 0.1 to $1.3 \mathrm{mg} / \mathrm{L}$. In the upgradient well JF13, benzene concentrations decreased from 
1,500 to $800 \mu \mathrm{g} / \mathrm{L}$, and dissolved-oxygen concentrations increased from 0.2 to $0.6 \mathrm{mg} / \mathrm{L}$. The decrease in these benzene concentrations could be due to biodegradation, dilution, movement of the contaminant to the bay, or any combination of these processes. The decrease in benzene concentration with the corresponding increase in dissolved oxygen indicates that conditions are improving at this site. In ground-water samples from the surficial aquifer during Phase I sampling, the cyanide concentrations of $11 \mu \mathrm{g} / \mathrm{L}$ at well JF 23 and $21 \mu \mathrm{g} / \mathrm{L}$ at well JF13 were below the MCL of $200 \mu \mathrm{g} / \mathrm{L}$. During Phase II sampling, the cyanide concentrations were less than $10 \mu \mathrm{g} / \mathrm{L}$ in ground water from both these wells. Cyanide is a breakdown product of bromobenzylcyanide, which may have been disposed of in the pits. Methyl-isobutyl ketone (MIBK), a solvent, was detected at $1,100 \mu \mathrm{g} / \mathrm{L}$ in well JF13 in Phase I, but was not detected during Phase II. During Phase I, $24 \mu \mathrm{g} / \mathrm{L}$ of phenols were detected in ground water from well JF13. During Phase II sampling, phenols were detected at concentrations of $13 \mu \mathrm{g} / \mathrm{L}$ in well JF13 and $2 \mu \mathrm{g} / \mathrm{L}$ in well JF23. Phenols can be a degradation product of naturally occurring plant debris; however, it can also be a breakdown product of disinfectants that might have been used to neutralize chemical agents during the disposal processes.

In confining-unit well JF22 during Phase I sampling, cyanide was detected at a concentration of $66 \mu \mathrm{g} / \mathrm{L}$ and 1,1,1-TCA was detected at a concentration of $3 \mu \mathrm{g} / \mathrm{L}$. 1,1,1-TCA is a breakdown product of mustard agent. During Phase II sampling, $17.1 \mu \mathrm{g} / \mathrm{L}$ of cyanide, $4 \mu \mathrm{g} / \mathrm{L}$ of benzene and $4 \mu \mathrm{g} / \mathrm{L}$ of chloroethane were detected in well $\mathrm{JF12}$, which is upgradient of the disposal pit. Phenols at a concentration of $2 \mu \mathrm{g} / \mathrm{L}$ were detected in well JF22, which is downgradient of the pit.

In the confined-aquifer wells at the riot-controlagent disposal area, no organic compounds were detected in either Phase I or Phase II samples that indicated contamination in the aquifer. Four SVOC's, at concentrations of less than $4 \mu \mathrm{g} / \mathrm{L}$, were detected but these compounds also were found in trip, field, and laboratory blanks, indicating a bias in the analyses (Phelan and others, 1996).

\section{Contamination at the Riot-Control-Agent Disposal Area}

Because no soil, surface-water, and groundwater samples were collected from the areas where the soil-gas data indicated a contaminant plume, no confirmation of the soil-gas data is possible. Contaminant distribution based on the soil-gas data does not correlate with the direction of groundwater flow from the disposal pit, or with the pattern or type of organic compounds detected in the soil, surface water; or ground water. Contaminants detected in the soil-gas sampling may have been flushed from the site; however, because that sampling was performed over a year before soil, surface-water, and ground-water sampling were conducted for this study.

In soils in the riot-control-agent disposal area, lead was the only inorganic contaminant detected above background ranges. Organic contamination of soils was not evident.

The lead concentration of $26 \mu \mathrm{g} / \mathrm{L}$ at surfacewater site JFSW5, which is downgradient of the disposal pit, was the second highest concentration measured in surface water at J-Field, and almost twice the MCL for lead. The concentration of total aluminum in surface water at site JFSW5 was $7,400 \mu \mathrm{g} / \mathrm{L}$, but was primarily due to particulate matter rather than to dissolved aluminum. No evidence is available of organic contamination of surface water downgradient of the riot-controlagent disposal area.

No ground-water samples from wells near the riot-control-agent disposal area had high $\mathrm{pH}$ values similar to those detected in ground water at the toxic-materials disposal area and the whitephosphorus disposal area. Trace metal concentrations in ground water did not exceed those in control wells screened in the surficial aquifer, the confining unit, and the confined aquifer. Although lead contamination was found in soils and surface water, it was not detected in ground water.

Benzene and cyanide were both detected upgradient and downgradient of the disposal pit in ground water from the surficial aquifer during Phase I. The decrease of benzene concentrations between Phase I and Phase II sampling could be due to natural attenuation, dilution, movement of the contaminant to the bay, or any combination of these processes. Cyanide concentrations of 11 and $21 \mu \mathrm{g} / \mathrm{L}$ in ground water in the surficial aquifer during Phase I were below the MCL of $200 \mu \mathrm{g} / \mathrm{L}$. 
Cyanide at a concentration of $66 \mu \mathrm{g} / \mathrm{L}$ and $1,1,1-\mathrm{TCA}$ at a concentration of $3 \mu \mathrm{g} / \mathrm{L}$ were detected in wells in the confining unit during Phase I. Cyanide at a concentration of $17.1 \mu \mathrm{g} / \mathrm{L}$, benzene at a concentration of $4 \mu \mathrm{g} / \mathrm{L}$, chloroethane at a concentration of $4 \mu \mathrm{g} / \mathrm{L}$, and phenols at a concentration of $2 \mu \mathrm{g} / \mathrm{L}$ were detected in the confining unit during Phase II. No pattern of inorganic or organic contamination was found in the confining unit between Phase I and II groundwater sampling.

Phenols were the only contaminant (inorganic or organic) detected in the confined aquifer at the riot-control-agent disposal area. Phenols can be a degradation product of naturally occurring plant debris; however, it also can be a breakdown product of disinfectants that might have been used to neutralize chemical agents during the disposal processes.

\section{Assessment of the Robins Point Demolition Area}

Most emergency ordnance-disposal activities for the Edgewood area of APG take place at the Robins Point demolition area (fig. 2). Munitions are destroyed by placing enough explosives around the object to destroy it and any chemicals that it might contain. There are no known disposal pits or past chemical disposal activities in the area.

Surface water in the area flows to the east toward a tidal marsh, but a man-made sediment-control berm downhill (east) of the demolition area collects the runoff before it reaches the marsh. This berm allows the ponded water to either evaporate or seep into the ground. Ground water in the surficial aquifer flows toward the east and toward the tidal marsh (fig. 2). A soil-gas survey was not performed in this area. Three wells are screened in the surficial aquifer in this area--TH7, JF153, and JF163. Wells JF153 and JF163 were drilled after Phase I ground-water sampling was completed. There are no wells in this area that are screened in the confining unit or confined aquifer.

\section{Soils}

Five soil samples were taken at sites JS37-JS41 in April 1991 at the Robins Point demolition area (fig. 7). Inorganic constituents and organic compounds detected in soils are presented in tables 5 and 7, respectively. Arsenic, chromium, copper, and lead were detected at most of the five sites.
Median concentrations of trace metals in soils at the site (table 17) were similar to median concentrations detected in soils at Carroll Island (Tenbus and Phillips, 1996, p. 56). The median concentration of copper, however, was $7.9 \mu \mathrm{g} / \mathrm{g}$, which exceeded the median copper concentration of $4.5 \mu \mathrm{g} / \mathrm{g}$ at Carroll Island. The enrichment factors calculated for trace metals are shown in table 17. Slight enrichment of arsenic, copper, and lead are in soils indicated at the Robins Point demolition area.

Benzoic acid and benzyl-butyl-phthalate were the only organic compounds detected in soils at the Robins Point demolition area (table 7). Benzoic acid is a naturally occurring compound that was detected in many soil samples at J-Field. Benzylbutyl-phthalate was detected at levels of $0.72 \mu \mathrm{g} / \mathrm{g}$ or less in seven samples at J-Field. Duplicate samples were collected at two of the seven sites. In each of the two duplicate pairs, the benzylbutyl-phthalate was detected in one sample but not in the corresponding duplicate sample; therefore, the detections are questionable and were not considered in the interpretation.

\section{Surface Water}

Surface-water samples were collected at sites JFSW 17, 18, and 19 in the spring of 1993, and only at site JFSW18 in the fall of that year (fig. 8) because sites 17 and 19 were dry. These sites are east and downhill of the demolition area. Sites JFSW 17 and 19 are located at the edge of the tidal marsh, and site JFSW18 is closer to the demolition area, uphill of a sediment-control berm that collects rainwater that flows directly from the site. Inorganic water-quality data from the sites are shown in table 8 . Concentrations of organic compounds are shown in table 9.

\section{Inorganic Constituents}

Surface water at site JFSW 18 is ponded rainwater that flows directly from the demolition area, which is contained by an artificial berm. Specific conductance values and major ion concentrations at site JFSW18 during both the spring and fall sampling in 1993 were lower than nearly all other sites at J-Field (table 8), indicating fresher water that probably has a low residence time in the ground-water system. No lead was detected and aluminum concentrations were slightly below the 


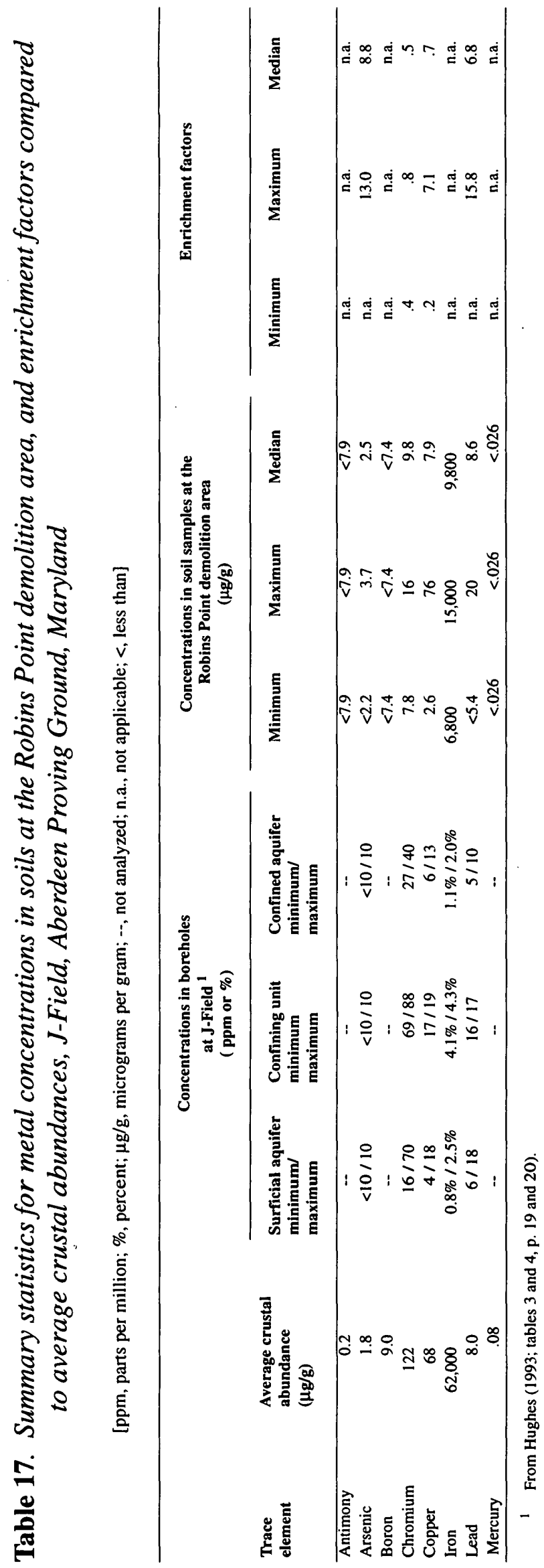


MCL of $200 \mu \mathrm{g} / \mathrm{L}$ and below the median concentration of $250 \mu \mathrm{g} / \mathrm{L}$ in surface water at all sites at J-Field. Concentrations of copper at site JFSW18 were similar to other surface-water sites at J-Field. Chromium concentrations at site JFSW1 18 were $7 \mu \mathrm{g} / \mathrm{L}$ in the spring and $8 \mu \mathrm{g} / \mathrm{L}$ in the fall.

Major-ion chemistry and trace metal concentrations at sites JFSW17 and JFSW19 were similar to other marsh sites around J-Field. The chromium concentration at site JFSW 17, however, was $10 \mu \mathrm{g} / \mathrm{L}$, which was the highest concentration in surface water at J-Field but was within the normal range for natural waters (Hem, 1985). The maximum concentration of chromium in surface water at Carroll Island was $20 \mu \mathrm{g} / \mathrm{L}$ (Tenbus and Phillips, 1996). Aluminum was detected at a concentration of $3,000 \mu \mathrm{g} / \mathrm{L}$ in the marsh at site JFSW17. Most of this aluminum was probably from colloidal material rather than dissolved aluminum.

\section{Organic Compounds}

No organic compounds were detected in surface water at the Robins Point demolition area in either the spring or fall of 1993 , indicating no contamination in this area.

\section{Ground Water}

Well TH7 is screened in the surficial aquifer, is upgradient of the demolition area, and is adjacent to Robins Point Road (fig. 9). Well JF163 is screened in the surficial aquifer, is upgradient of the demolition area, is uncontaminated, and is a control well. Well JF153 also is screened in the surficial aquifer, and is downgradient of the demolition area. No wells are screened in deeper formations in this area. Well TH7 was sampled only during Phase I, and wells JF153 and JF163 were sampled only during Phase II.

\section{Inorganic Constituents}

Physical properties measured in ground water in wells TH7, JF163, and JF153 were within the range of these properties in control wells (table 3). Major ion and trace metal concentrations in the surficial aquifer in well TH7 in Phase I and wells JF153 and JF163 in Phase II are all below the average concentrations for these constituents in the surficial aquifer (Phelan and others, 1996, tables 17 and 19). Therefore, no inorganic contamination in ground water in the surficial aquifer is indicated at this site.

\section{Organic Compounds}

The only organic compound detected during Phase I in well TH7, which is upgradient of the disposal area, was 2-nitrophenol, which was at the detection limit of $8.2 \mu \mathrm{g} / \mathrm{L}$. The well was not resampled during Phase II. There were no detections of organic compounds in well JF163, which is upgradient of the demolition area. Of 23 organic compounds detected in well JF153, all 23 had concentrations that were estimated values below the reporting limit, and seven of these compounds also had been detected at low levels in the associated blank (Phelan and others, 1996). The organic compounds detected in well JF153 did not exceed any established MCL's. In a sample from well JF153 that was collected by Argonne National Laboratory in 1994, RDX at a concentration of $2.9 \mu \mathrm{g} / \mathrm{L}$ was the only organic compound detected (Louis Martino, Argonne National Laboratory, written commun., 1997).

\section{Contamination at the Robins Point Demolition Area}

In the five soil samples collected from this area, slight enrichment of arsenic, copper, and lead and no evidence of organic contamination were indicated.

Three surface-water sites were sampled in the spring, and only one site was resampled in the fall of 1993 because the other two sites were dry. The low concentrations of inorganic constituents and the absence of organic compounds in surface water at the Robins Point demolition area indicate no contamination of surface water in this area.

Ground water from well JF163, which is upgradient from the demolition area, showed no indications of inorganic or organic contamination. No inorganic contamination of ground water in the surficial aquifer was indicated at this site. The only organic compound detected in well TH7 during Phase I was 2-nitrophenol, which was at the detection limit of $8.2 \mu \mathrm{g} / \mathrm{L}$. This well was not resampled during Phase II. Concentrations were less than the reporting limit and below all established MCL's for the 23 organic compounds detected in Phase II ground-water samples from 
well JF153, which is downgradient of the demolition area.

\section{Assessment of the Prototype Building Area}

The prototype building is a three-story, steelreinforced, open concrete structure (fig. 2) that was probably used to store chemicals, and is surrounded by an open area where the grass is usually mowed twice a year. The building was designed to simulate typical German construction practices during World War II, and was used to determine the effectiveness of various weapons on the building. The numerous circular stains on the concrete floor of the building probably resulted from the rusting of storage drums (Hughes, 1993), although no records exist of such use. There are no known disposal pits or past chemical disposal activities in the area. Surface-water runoff and ground-water flow in the surficial aquifer are to the west, toward the tidal Gunpowder River (fig. 5).

A soil-gas survey was not performed in this area. Surface-water samples were not collected because no ponds or marshes are present in the area.

Soils

Five soil samples were taken at sites JS11-JS15 near the prototype building in April 1991 (fig. 7). Inorganic constituents and organic compounds detected in soils are presented in tables 5 and 7 , respectively. Arsenic, chromium, copper, lead, and mercury were detected in most of the five soil samples. Of these constituents, only the maximum lead concentration of $93 \mu \mathrm{g} / \mathrm{g}$ at site JS15 adjacent to the building had enrichment factors that indicated contamination (table 18). The median lead concentration in the five samples near the building $(25 \mu \mathrm{g} / \mathrm{g})$ was only slightly higher than the median lead concentrations for all soils at J-Field, $(17 \mu \mathrm{g} / \mathrm{g})$ and at Carroll Island (19.6) (Tenbus and Phillips, 1996). The high concentration of lead at JS15 could be the result of munitions testing that was performed at the building during World War II.

The only organic compound detected in soils in the prototype building area was 1,1,1-TCA at a concentration of $.009 \mu \mathrm{g} / \mathrm{g}$ at site JS15, the same site with the highest concentration of lead. With the exception of the concentrations of 1,1,1-TCA and lead at site JS15, soils in the area around the prototype building do not appear to be contaminated because of disposal or ordnance-testing activities.

\section{Ground Water}

The six wells located in the prototype building area are shown in figure 9. Well TH5 was not sampled during this study, and well TH6 was sampled only during Phase I. The other four wells were sampled during both Phase I and Phase II. The five wells that were sampled and the hydrogeologic units the wells are screened in are listed in the following table.

\begin{tabular}{lll}
\hline $\begin{array}{l}\text { Surficial-aquifer } \\
\text { wells }\end{array}$ & $\begin{array}{l}\text { Confining-unit } \\
\text { wells }\end{array}$ & $\begin{array}{l}\text { Confined-aquifer } \\
\text { wells }\end{array}$ \\
\hline JF33 & JF32 & JF31 \\
TH6* & \\
TH8 & \\
* denotes wells sampled only during Phase I; BOLD well numbers \\
denote control wells
\end{tabular}

No wells in the prototype building area had high $\mathrm{pH}$ values similar to those at the toxicmaterials disposal area or at the white-phosphorus disposal area. Specific conductance, $\mathrm{pH}$, dissolved oxygen, and alkalinity in the area were within the range of these same parameters in the control wells for the respective hydrogeologic units (table 3), with the exception of specific conductance in well JF33, which was $730 \mu \mathrm{S} / \mathrm{cm}$ in Phase I and $570 \mu \mathrm{S} / \mathrm{cm}$ in Phase II.

\section{Inorganic Constituents}

Concentrations of calcium, magnesium, sodium, sulfate, and chloride in well JF33 were higher than those in control well TH6. The total dissolved solids concentration of $540 \mathrm{mg} / \mathrm{L}$ in well JF33 in Phase I was 4.5 times the concentration in well TH6 (Phelan and others, 1996, p. 117). The maximum chloride concentration in wells in the surficial aquifer in the area is $15 \mathrm{mg} / \mathrm{L}$, which does not indicate brackish-water intrusion. 


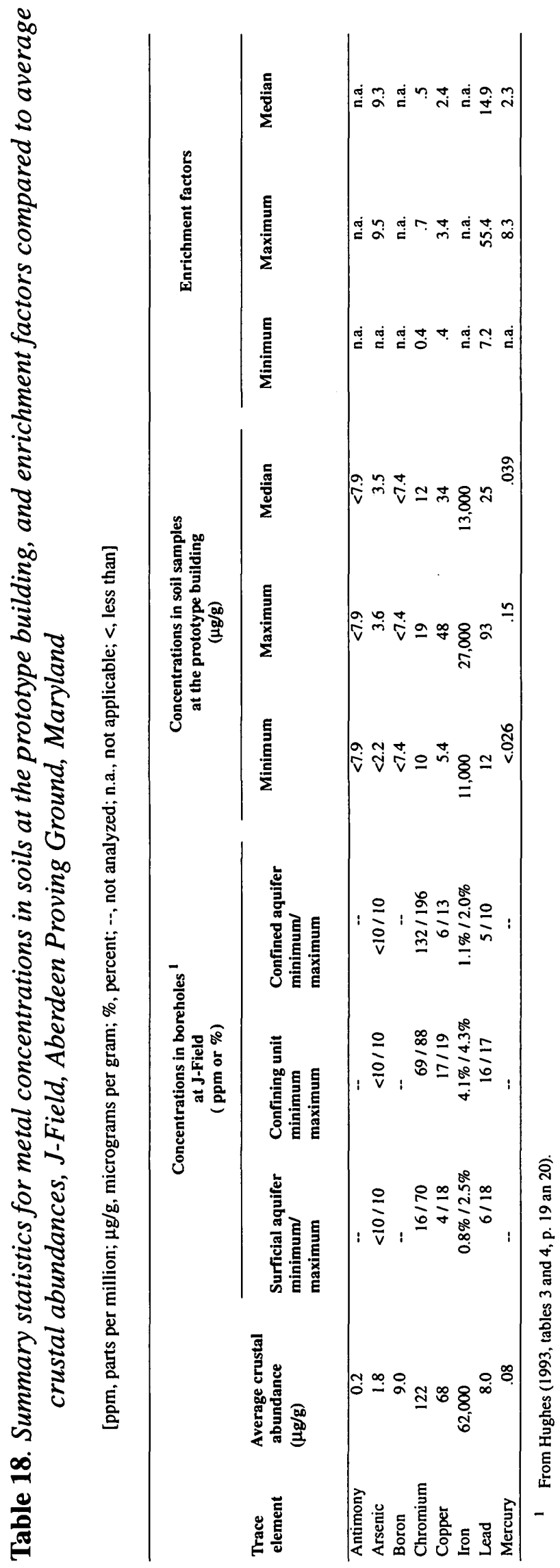


Dissolved trace-metal concentrations (in micrograms per liter) detected in the ground water for Phase I and II in wells near the prototype building are presented in the following table.

\begin{tabular}{|c|c|c|c|c|c|}
\hline \multirow{2}{*}{$\begin{array}{l}\text { Well } \\
\text { No. }\end{array}$} & \multirow{2}{*}{$\begin{array}{l}\text { Aluminum } \\
\text { Phase I }\end{array}$} & \multicolumn{2}{|c|}{ Barium } & \multirow{2}{*}{$\begin{array}{l}\text { Boron } \\
\text { Phase I }\end{array}$} & \multirow{2}{*}{$\begin{array}{l}\text { Cobalt } \\
\text { Phase II }\end{array}$} \\
\hline & & Phase I & Phase II & & \\
\hline
\end{tabular}

\begin{tabular}{rrrrrr} 
TH6 $^{1}$ & 130 & 15 & - & - & - \\
TH8 & $<110$ & 25 & 21 & 420 & $<6$ \\
JF33 & $<110$ & 41 & 40 & 320 & 4.2 \\
JF32 & $<110$ & 110 & 80 & $<230$ & $<4$ \\
JF31 & $<110$ & 67 & 65 & $<230$ & $<4$ \\
\hline
\end{tabular}

I Well TH6 is a control well.

Aluminum was only detected in the control well, and not in the wells downgradient of the building. No barium concentrations exceeded the maximum concentrations in control wells. Boron concentrations of up to a few hundred micrograms per liter can be expected in many types of surface and ground water (Hem, 1985, p. 129). Hem (1985 p. 139) also states that natural or uncontaminated water generally should contain no more than a few micrograms per liter of cobalt, which is near the concentration of cobalt in well TH8. On the basis of the above data, there are no indications of inorganic ground-water contamination in the vicinity of the prototype building.

\section{Organic Compounds}

During Phase I sampling, benzene at a concentration of $6.4 \mu \mathrm{g} / \mathrm{L}$ and MIBK at a concentration of $120 \mu \mathrm{g} / \mathrm{L}$ were detected in ground water from well TH8, which is presently (1997) less than $30 \mathrm{ft}$ from the tidal Gunpowder River beach because of shoreline erosion. No organic compounds were detected during Phase I in wells TH6, JF31, JF32, or JF33, that are farther from the river (fig. 9). During Phase II sampling, the only organic compounds detected in the prototype building area were low concentrations of methylene chloride, methyl ethyl ketone, and bis 2-ethyl hexyl phthalate (well TH6 was not sampled in Phase II), which also were found at low concentrations in the associated laboratory blanks
(Phelan and others, 1996). The lack of reproducibility of the concentrations of benzene and methyl isobutyl ketone between Phase I and Phase II may be related to the spatially and temporally heterogeneous nature of the contaminant distribution, or to attenuation, or to discharge of contaminated ground water to the Gunpowder River. On the basis of this lack of reproducibility and the lack of other organic compounds detected in Phase II, no organic contamination of ground water was evident as of Phase II in the area of the prototype building.

\section{Contamination at the Prototype Building Area}

A soil-gas survey was not performed in the prototype building area. Surface-water samples were not collected because no ponds or marshes are present in the area. With the exception of a concentration of $93 \mu \mathrm{g} / \mathrm{g}$ of lead, and a detection of $.009 \mu \mathrm{g} / \mathrm{g}$ of $1,1,1-\mathrm{TCA}$ at site JS15 adjacent to the building, soils near the prototype building do not appear to be contaminated because of ordnance disposal or testing activities. Detections of aluminum, barium, boron, and cobalt in ground water were generally similar to concentrations found in natural systems, and do not indicate tracemetal contamination in the ground water in the surficial aquifer, confining unit, or confined aquifer. No organic contamination of ground water was evident as of Phase II in the area.

\section{SUMMARY AND CONCLUSIONS}

J-Field is located at Aberdeen Proving Ground, on the western shore of the Chesapeake Bay in Harford County, Maryland. It has been used by the U. S. Army since World War I as a testing ground for munitions, including chemical-warfare agents. From shortly after World War II into the 1970's, chemical-warfare agents, high-explosive munitions, and industrial chemicals were tested and disposed of at J-Field by open-pit burning and by high-explosive demolition. Only emergency disposal operations have been conducted at J-Field since the early 1980's. Soil, surface-water, and ground-water contamination has resulted from the migration of unburned chemicals and fuels from the disposal areas. Discharge of contaminants from ground water and runoff has resulted in contamination of the marshes and ponds at J-Field. 
This study was conducted from 1989 to 1994 as part of a remedial investigation of J-Field in response to the Comprehensive Environmental Response, Compensation, and Liability Act (CERCLA) requirements. The ground-waterquality data for this study were collected in two phases: Phase I data were collected in 1990, and Phase II data were collected during 1992-93. Soilquality data were collected in 1991 and surfacewater-quality data were collected in 1993. The nature and extent of contamination of soil, surface water, and ground water due to disposal of military ordnance, chemical surety materials, and other hazardous waste are described at five sites at J-Field: the toxic-materials disposal area, the white-phosphorus disposal area, the riot-controlagent disposal area, the Robins Point demolition area, and the prototype building. Information from this study will be used to support a Remedial Investigation and Feasibility Study for J-Field.

Relatively uncontaminated sites were selected as control sites to provide a basis for comparison with contaminated sites or sites that were suspected to be contaminated. Because no control sites were available for soils at J-Field, concentrations of metals in soils at contaminated sites were compared to average crustal abundances or to ranges typically found in natural soils. Because most surface-water runoff at J-Field originates at or near known contaminated areas, and because past burning and current demolition activities provide a potential source of atmospheric contaminants, no surface-water sites were considered representative of background conditions. Eight wells screened in the surficial aquifer, four wells in the confining unit, and four wells in the confined aquifer met the criteria for designation as ground-water-control wells.

The toxic-materials disposal area was the most contaminated of the five sites investigated at J-Field. Most of the soil and surface-water contamination was detected in the marsh area to the east of the disposal pits, where waste was pushed after the burning activities. High concentrations of lead, antimony, cadmium, chromium, copper, and mercury were detected in soils at the edge of this marsh. Lead concentrations as high as $51 \mu \mathrm{g} / \mathrm{L}$ and concentrations of other trace metals were highest in surface water at the edge of the marsh. Volatile organic com- pounds (VOC's), including 1,1,2,2-tetrachloroethane (PCA), 1,1,2-trichloroethane (TCA), tetrachloroethene (PCE), trichloroethene (TCE), 1,2-dichloroethylene (DCE), vinyl chloride, and toluene, were detected (with concentrations of 1,1,2,2-PCA as high as 2,300 micrograms per liter $(\mu \mathrm{g} / \mathrm{L})$ at site JFSW10) in surface-water samples collected at the edge of this marsh.

Significant ground-water contamination was evident at the toxic-materials disposal area, particularly in the surficial aquifer in areas adjacent to and downgradient of the disposal pits. VOC concentrations from wells screened in the surficial aquifer in these areas increased considerably between Phase I and Phase II sampling. In ground water from the surficial aquifer, major contaminants included arsenic $(60 \mu \mathrm{g} / \mathrm{L}$ in Phase I), TCE $(41,000 \mu \mathrm{g} / \mathrm{L}$ in Phase II), and 1,2-DCE $(12,000 \mu \mathrm{g} / \mathrm{L}$ in Phase II); however, lesser amounts of nickel, antimony, PCA, 1,1,2-TCA, PCE, and vinyl chloride also were detected. Some of these organic compounds, particularly 1,1,2-TCA, 1,2DCE, and vinyl chloride, may be breakdown products of the original compounds. The concentration of $260,000 \mu \mathrm{g} / \mathrm{L}$ of $1,1,2,2$-PCA during Phase II sampling at well JF83 indicates the presence of dense non-aqueous phase liquid (DNAPL) in the surficial aquifer.

Evidence of ground-water contamination also was found in the confining unit and confined aquifer at the toxic-materials disposal area. The $\mathrm{pH}$ values exceeded 8.0 in wells JF72 and JF82 screened in the confining unit and in wells JF51, JF61, JF71, and JF81 screened in the confined aquifer. Alkalinity values also were high in these wells. Possible causes for these high $\mathrm{pH}$ and high alkalinity values include (1) compounds generated from the burning activities at the pits, (2) use of bulk sodium hydroxide to neutralize chemical agents, and (3) grout contamination due to wellinstallation procedures. Although VOC's were detected in samples from the confined aquifer wells downgradient of the disposal pits (JF51, JF61, JF71, and JF81) during both Phase I and II, the VOC concentrations in each of these wells declined substantially between the sampling phases. This decline indicates that the drilling process was the probable source of VOC contamination in the confined aquifer, dilution of 
these contaminants has occurred between the two sampling phases, and that no continuous source of contaminants is present in the confined aquifer.

The degree of contamination at the whitephosphorus disposal area was appreciably less and was less extensive than at the toxic-materials disposal area. Soil, surface-water, and groundwater contamination was localized rather than widespread at the white-phosphorus disposal area. The major contaminants detected in the surficial aquifer were TCE and lead. TCE was detected at a concentration of $40 \mu \mathrm{g} / \mathrm{L}$ in Phase I and $310 \mu \mathrm{g} / \mathrm{L}$ in Phase II in samples from well P7, which is screened in the surficial aquifer and downgradient of the disposal pits. No TCE was detected in wells screened in the confining unit or confined aquifer. Lead was detected during Phase I sampling in well $\mathrm{TH} 1$ at a concentration of $120 \mu \mathrm{g} / \mathrm{L}$, which is about eight times the maximum contaminant level (MCL). TH1 was the only well at J-Field with detectable concentrations of lead. This well is screened in the surficial aquifer and is located north of the disposal pits, downgradient of an area where lead was detected in soil samples.

At the riot-control-agent disposal area, lead was the only inorganic compound detected above background ranges in soils. The lead concentration of $26 \mu \mathrm{g} / \mathrm{L}$ at site JFSW5, which is downgradient of the disposal pit, was the second highest concentration detected in surface water at J-Field, and almost twice the MCL for lead. Although lead contamination was detected in soils and surface water, it was not detected in ground water at this site. There was no evidence of organic contamination of soils or of surface water downgradient of the riot-control-agent disposal area. Trace metal concentrations in ground water did not exceed those in the ground-water-control wells in the surficial aquifer, confining unit, and confined aquifer. Benzene and cyanide were detected upgradient and downgradient of the disposal pit in surficial aquifer wells during Phase I; concentrations of both compounds decreased in Phase II.
Methyl-isobutyl ketone (MIBK) was detected at a concentration of $1,100 \mu \mathrm{g} / \mathrm{L}$ in surficial-aquifer well JF13 in Phase I, but was not detected in Phase II. Cyanide $(66 \mu \mathrm{g} / \mathrm{L}), 1,1,1-\mathrm{TCA}(3 \mu \mathrm{g} / \mathrm{L})$, benzene $(4 \mu \mathrm{g} / \mathrm{L})$, chloroethane $(4 \mu \mathrm{g} / \mathrm{L})$, and phenols $(2 \mu \mathrm{g} / \mathrm{L})$ were detected in ground water from the confining unit. Phenols were the only organic compound detected in the confined aquifer during Phase I and II.

At the Robins Point demolition area, which is used for most emergency ordnance demolition for the Edgewood Area of APG, there are no known disposal pits or past disposal activities. Slight enrichment of arsenic, copper, and lead, but no evidence of organic contamination was found in the five soil samples collected from this area. In surface-water samples, low concentrations of inorganic constituents were found, and organic compounds were not detected. There is no indication of inorganic contamination of ground water in the surficial aquifer at this site. Concentrations were less than the reporting limit and any established MCL's for the 23 organic compounds detected in Phase II ground-water samples from surficial aquifer well JF153, which is downgradient of the demolition area. Seven of the 23 organic compounds also were detected in associated blank samples. No wells at this site are screened in the confining unit or in the confined aquifer.

Contamination at the prototype building area was very localized. Soil-sampling site JS15, which was next to the building, had elevated levels of lead (93 micrograms per gram $[\mu \mathrm{g} / \mathrm{g}]$ ) and $1,1,1$ TCA $(.009 \mu \mathrm{g} / \mathrm{g})$. With the exception of this site, soils near the prototype building did not appear to be contaminated because of ordnance disposal or testing activities. Surface-water samples were not collected because no ponds or marshes are present in the area. No evidence was found of inorganic or organic ground-water contamination in Phase II samples taken in the vicinity of the prototype building. 


\section{SELECTED REFERENCES}

Brady, N.C., 1974, The nature and properties of soils, 8th edition: Macmillan Publishing Co., Inc., New York, $639 \mathrm{p}$.

Chapelle, F.H., 1993, Ground-water microbiology and geochemistry: John Wiley and Sons, Inc., New York, $424 \mathrm{p}$.

Greenwood, N.N., and Earnshaw, A., 1986, Chemistry of the elements: Pergamon Press, Oxford, 1, $543 \mathrm{p}$.

Hem, J.D., 1985, Study and interpretation of the chemical characteristics of natural water: U.S. Geological Survey Water-Supply Paper 2254, $263 \mathrm{p}$.

Hughes, W.B., 1991, Application of marine-seismic profiling to a ground-water contamination study, Aberdeen Proving Ground, Maryland: Ground Water Monitoring Review, v. 11, no. 1, p. 97-102. 1993, Hydrogeology and soil gas at J-Field, Aberdeen Proving Ground, Maryland: U.S. Geological Survey Water-Resources Investigations Report 92-4087, 83 p. 1995, Ground-water flow and the possible effects of remedial actions at J-Field, Aberdeen Proving Ground, Maryland: U.S. Geological Survey Water-Resources Investigations Report 95-4075, $75 \mathrm{p}$.

Lorah, M.M., and Vroblesky, D.A., 1989, Inorganic and organic ground-water chemistry in the Canal Creek area of Aberdeen Proving Ground, Maryland: U.S. Geological Survey WaterResources Investigations Report 89-4022, 97 p.

Maryland Department of the Environment, 1988, Code of Maryland Regulations Section 26.08.02.09: Office of the Secretary of State, Annapolis, Maryland, p. 502-503.

Minard, J.P., May, F.E., and Christopher, R.A., 1980, Geology of the Round Bay quadrangle, Anne Arundel County, Maryland: U.S. Geological Survey Professional Paper 1109, 30 p.

Montgomery, J.H., and Welkom, L.M., 1990, Groundwater chemicals desk reference: Chelsea, Mich., Lewis Publishers, Inc., 492 p.

Nemeth, Gary, 1989, RCRA facility assessment report, Edgewood Area: Aberdeen Proving Ground, Maryland: U.S. Army Toxic and Hazardous Materials Agency Project No. 39-260490-90, 929 p.
Nemeth, Gary, Murphy, J.M., and Zarzycki, J.H., 1983, Environmental survey of the Edgewood Area of Aberdeen Proving Ground, Maryland: Aberdeen Proving Ground, Maryland, U.S. Army Toxic and Hazardous Materials Agency Report No. DRXTH-AS-FR-82185, 265 p.

Phelan, D.J., Marchand, E.H., Cashel, M.L., Koterba, M.T., Olsen, L.D., and Nemoff, P.R., 1996, Hydrogeologic, soil, and water-quality data for J-Field, Aberdeen Proving Ground, Maryland: U.S. Geological Survey Open-File Report 96-128, $191 \mathrm{p}$.

Powars, D.S., 1997, Stratigraphy and geophysical logs from a corehole drilled to bedrock at Robins Point, J-Field, Edgewood Area, Aberdeen Proving Ground, Maryland: U.S. Geological Open-File Report 97-357, 68 p.

Princeton Aqua Science, 1984, Munitions disposal study: Aberdeen Proving Ground, Maryland, Environmental Management Office, $44 \mathrm{p}$.

Smith, J.A., Witkowski, P.J., and Fusillo, T.V., 1988, Manmade organic compounds in the surface waters of the United States--A review of current understanding: U.S. Geological Survey Open-File Report 90-181, $110 \mathrm{p}$.

Stumm, Werner, and Morgan, J.J., 1996, Aquatic chemistry (3rd edition): New York, Wiley Interscience, $1022 \mathrm{p}$.

Tenbus, F.J., and Blomquist, J.D., 1995, Hydrogeology and water quality in the Graces Quarters area of Aberdeen Proving Ground, Maryland: U.S. Geological Survey WaterResources Investigations Report 94-4175, $115 \mathrm{p}$.

Tenbus, F.J., and Phillips S.W., 1996, Hydrogeology and chemical quality of water and soil at Carroll Island, Aberdeen Proving Ground, Maryland: U.S. Geological Survey Water-Resources Investigations Report 96-4169, 156 p.

Thurman, E.M., 1986, Organic geochemistry of natural waters: Martinus Nijhoff/Dr. W. Junk Publishers, $497 \mathrm{p}$.

U.S. Environmental Protection Agency, 1986, Quality criteria for water: U.S. Environmental Protection Agency-440/5-86-001: Washington, D.C., U.S. Environmental Protection Agency Office of Water Regulations and Standards, variously paged. 
1989, Proposed rule, National primary and secondary drinking water regulations (sections 141.50, 141.51, 141.61, and 141.62 of part 141 and 143.3 of part 143) U.S. Federal Register, v. 54, no. 97, May 22, 1989, p. 22, 062-22, 160. 1990a, Maximum contaminant levels (subpart B of part 141, National primary drinking water regulations): U.S. Code of Federal Regulations, Title 40, Parts 100 to 149 , revised as of July 1, 1990, p. 559-563.

1990b, Maximum contaminant łevel goals (subpart F of part 141, National primary drinking water regulations): U.S. Code of Federal Regulations, Title 40, Parts 100 to 149 , revised as of July 1, 1990, p. 620-621.

$1990 \mathrm{c}$, National revised primary drinking water regulations: Maximum contaminant levels (subpart G of part 141, National primary drinking water regulations): U.S. Code of Federal Regulations, Title 40, Parts 100 to 149 , revised as of July 1, 1990, p. 621-622.

1990d, Secondary maximum contaminant levels (sections 143.3 of part 143, National secondary drinking water regulations): U.S. code of Federal Regulations, Title 40, Parts 100 to 149, revised as of July 1, 1990, p. 674.

1990e, Proposed rule, National primary and secondary drinking water regulations; Synthetic organic compounds and inorganic chemicals (sections 141.11, 141.12, 141.61, and 141.62 of part 141 and 143.3 of part 143) U.S. Federal Register, v. 55 , no. 143 , July 25,1990 , p. 30 , 370-30, 448.

1991a, Final rule, National primary and secondary drinking water regulations--Synthetic organic chemicals and inorganic chemicals (sections 141.11, 141.12, 141.32, 141.50, 141.51, 141.61 , and 141.62 , of part 141 and 143.3 of part 143) U.S. Federal Register, v. 56, no. 20, January 30, 1991, p. 3, 526-3, 597. 1991b, Final rule, Maximum contaminant level goals and national primary drinking water regulations for lead and copper (sections 141.11, 141.32, and 141.51 of part 141) U.S. Federal Register, v. 56, no. 110, July 7, 1991, p. 26, 460 26, 564.

1991c, Final rule, National primary drinking water regulations--MCLG's and MCL's for aldicarb, aldicarb sulfoxide, aldicarb sulfone, pentachlorophenol, and barium (sections 141.50, $141.51,141.61$, and 141.62 of part 141)

U.S. Federal Register, v. 56, no. 126, July 1, 1991, p. 30, 266-30, 281.

1992, Final rule, National primary and secondary drinking water regulations--Synthetic organic chemicals and inorganic chemicals (sections 141.12, 141.32, 141.50, 141.51, 141.61, and 141.62 of part 141 and 143.3 of part 143) U.S. Federal Register, v. 57, no. 138, July 17, 1992, p. 31, 776-31, 849.

Walker, S.E., 1983, Background ground-water quality monitoring: Well installation trauma, in the Third National Symposium on Aquifer Restoration and Ground-Water Monitoring, May 25-27, 1983, Columbus, Ohio, Proceedings: National Water Well Association, p. 235-246.

Williams, Camilla, and Evans, L.G., 1987, Guide to the selection of cement, bentonite and other additives for use in monitor well construction: Proceedings of the National Water Well Association's First National Outdoor Action Conference of Aquifer Restoration, Ground Water Monitoring and Geophysical Methods in Las Vegas, Nev., May 18-21, 1987, p. 4. 


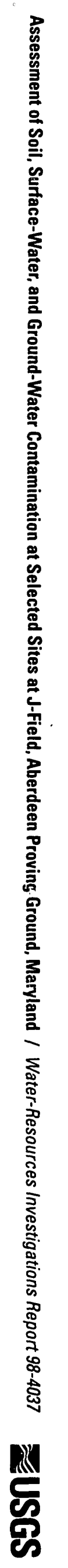

